\title{
Geological Conditions and Hydrocarbon Accumulation Processes in the Sahul Platform, Northern Bonaparte Basin, Australia
}

\author{
Rakotondravoavy Jules ${ }^{1,2}$, Jiaren Ye ${ }^{1}$, Qiang Cao ${ }^{1}$ \\ ${ }^{1}$ Key Laboratory of Tectonics and Petroleum Resources, China University of Geosciences, \\ MOE, Wuhan, China \\ ${ }^{2}$ Département des Sciences de la Terre et de l'Environnement à la Faculté des Sciences de \\ Technologies et de l'Environnement de l'Université de Mahajanga, Mahajanga, Madagascar \\ Email: 'rakoto@mail.ru
}

Received 14 May 2016; accepted 26 June 2016; published 29 June 2016

Copyright $@ 2016$ by authors and Scientific Research Publishing Inc.

This work is licensed under the Creative Commons Attribution International License (CC BY). http://creativecommons.org/licenses/by/4.0/

(c) (i) Open Access

\section{Abstract}

The Sahul Platform where the Sunset-Loxton Shoals and Chuditch gas fields were discovered is located between the Timor Trough to the north and the Malita Graben to the south. These areas are located respectively $440 \mathrm{~km}$ and $380 \mathrm{~km}$ northwest of Darwin in the northern Bonaparte Basin, Australia. Based on the structural evolution of the northern Bonaparte Basin, data from the wells Loxton Shoals 1, Sunset 1 and Chuditch 1 in the Sahul Platform and Heron 1 in the Malita Graben depocentre, and the Seismic Line $\mathrm{N11606}$ were used to clarify the geological conditions and reconstruct the hydrocarbon accumulation processes in the study area. BasinMod 1-D, 2-D, and 3-D software was used for modeling. The Plover Formation source rock was a poor-to-good hydrocarbon generative potential and reached the middle to late mature oil window in the Sunset-Loxton Shoals field whereas in the Chuditch field, it was an overall fair-to-good hydrocarbon generative potential, and attained the Late mature oil window. The Flamingo, and the Echuca Shoals formations source rocks in the same field were a fair and good hydrocarbon generation potential respectively, and both reached mid-mature oil window. In the Malita Graben depocentre, the Petrel (Frigate) and the Echuca Shoals formations source rocks were a poor-to-very good hydrocarbon generating potential, and had attained wet gas window at the present day. The analyses of organic matter showed that the source rocks in the study area and Malita Graben were gas prone with kerogen types $\mathrm{II}_{2} \&$ III and III predominantly. The Middle Jurassic Plover Formation sandstone reservoir in the Sunset-Loxton field was a poor-to-very good quality and potential for gas beds, and

${ }^{*}$ Corresponding author.

How to cite this paper: Jules, R., Ye, J.R. and Cao, Q. (2016) Geological Conditions and Hydrocarbon Accumulation Processes in the Sahul Platform, Northern Bonaparte Basin, Australia International Journal of Geosciences, 7, $792-827$. 
it was a very poor-to-very good quality and potential for gas beds in the Chuditch field. The intensities of gas generation and expulsion were more than of oil ones either in the Sahul Platform or in the Malita Graben. The Plover, Petrel (Frigate) and Echuca Shoals formations source rocks in the wells Chuditch 1 and Heron 1, except for the Flamingo Formation in the well Chuditch 1, had higher gas and oil expelling efficiencies than the Plover Formation source rock of the wells in the Sunset-Loxton Shoals field. The hydrocarbon migrated mainly from the Upper Jurassic Frigate Shale source rock in the Malita Graben depocentre (structurally lower) to the Plover Formation sandstone reservoir in the Sunset-Loxton Shoals field during the Late Cretaceous at $66 \mathrm{Ma}$. In the Chuditch field, the hydrocarbon migration to the Plover Formation sandstone reservoir was initiated during the Late Miocene at 7.5 Ma from the Middle Jurassic Plover Formation source rock in the well Chuditch 1. Nowadays, the main migration pathways are from the southeastward and southward of the Sunset-Loxton Shoals field, and from southward and eastward of the Chuditch field, precisely from the hydrocarbon source kitchens of the Malita Graben depocentre. The traps in the Sahul Platform have been effective to receive the migrated hydrocarbon.

\section{Keywords}

Basin Modeling, Hydrocarbon Accumulations, Northern Bonaparte Basin, Sahul Platform

\section{Introduction}

The Sahul Platform where was discovered the Sunset-Loxton Shoals (commonly referred to as the Greater Sunrise) and Chuditch gas fields is bounded by the Timor Trough to the north and Malita Graben to the south. These areas are located respectively, $440 \mathrm{~km}$ northwest of Darwin on the Troubadour High (referred to as the Sunrise High by [1]) and $380 \mathrm{~km}$ northwest of Darwin on the right flank (limb) of the Sikitan Syncline, in the northern Bonaparte Basin, Australia (Figure 1). The principal source rocks of the northern Bonaparte Basin comprise the shales of the Lower-Middle Jurassic Plover, upper Middle Jurassic (Callovian) Elang (Laminaria), Upper Jurassic-Lower Cretaceous Frigate (Cleia and Flamingo) and the Lower Cretaceous Echuca Shoals formations [2] [3]. The fluvio-deltaic to marine marginal Middle Jurassic Plover Formations are the primary reservoir targets within the Sahul Platform. The Jurassic Plover-Plover with level of certainty hypothetical (.) petroleum system is defined as the active petroleum system in the Sahul Platform and Malita Graben [4] followed the source-reservoir couplet nomenclature of [5]. The claystones of the Elang (Laminaria), Flamingo, Echuca Shoals, and Wangarlu formations provide vertical and lateral seal for the Plover Formation reservoirs. The previous works in the study area indicated that the Sunset-Loxton Shoals accumulation was appraised by the well Loxton Sholas 1, and was drilled in 1995 by Woodside Offshore Petroleum Pty Ltd. The drilling was intersected $64 \mathrm{~m}$ gross hydrocarbon column with a net to gross ratio of $43 \%$, average log porosity of $15.10 \%$ and average hydrocarbon saturation of 78\%, and by the drilling of additional well Sunset 1 in 1997 by Shell Development (Australia) Pty Ltd., it passed through 96 m gross hydrocarbon column with a net to gross ratio of 36\%, average $\log$ porosity of $16.50 \%$ and average hydrocarbon saturation of $71 \%$. The accumulation has reserves of 5.44 Tcf (Trillion cubic feet) gas and 243 MMbbls liquids [6] with low carbon dioxide levels (4 to 5 mol\%), reservoired within the Plover Formation sandstone, which is $80 \mathrm{~m}$ thick and is entrapped in a fault-bounded structural closure that has $180 \mathrm{~m}$ relief and covers an area of 75 by $50 \mathrm{~km}$ [7] in the Sunset-Loxton Shoals field. On the southern margin of the Sahul Platform, the well Chuditch 1 in 1998 was drilled by Shell Development (PSC 9) Pty Ltd. to test a mapped structural closure at the Plover Formation level, which was traversed $25.13 \mathrm{~m}$ gross hydrocarbon column with a net to gross ratio of $78 \%$, average log porosity of $12.50 \%$. Recoverable volumes reserves are estimated to be $0.70 \mathrm{Tcf}$ gas [8]. Condensate volumes were initially estimated at $15 \mathrm{bbls} / \mathrm{MMscf}$ gas; however, after correcting for the oil-based mud used, the liquid content decreased markedly to $0.7 \mathrm{bbl} /$ MMscf gas. Recent geochemical studies of the gases from the northern Sahul Platform Sunset-Loxton Shoals area, and in the Malita and Calder grabens indicate that they are sourced from the Plover Formation in the main depocentres and on the Heron and Troubadour terraces [9]. Presently, the trap total area is over 2076 $\mathrm{Km}^{2}$ in the Sunset-Loxton Shoals field and $981.30 \mathrm{Km}^{2}$ in the Chuditch field. These traps have been able 


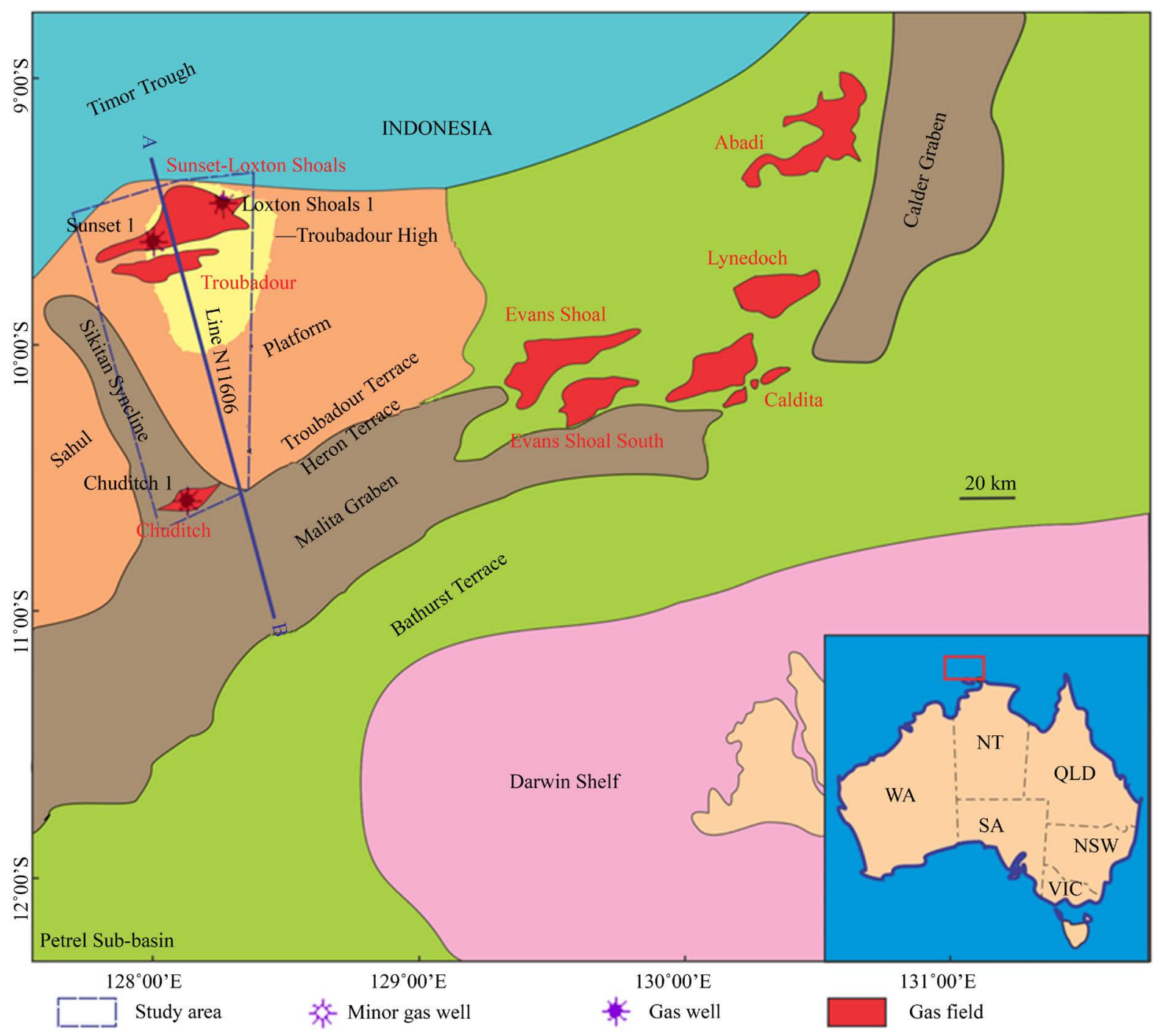

Figure 1. Study area map in the Sahul Platform of the northern Bonaparte Basin, Australia, showing the location of Chuditch and Sunset-Loxton Shoals gas fields.

to accommodate the migrated hydrocarbon mainly from the source rocks in the south margin of the study area and Malita Graben depocentre. Based on the previous works, the region is rich in hydrocarbon especially gas and condensate and it remains sparsely explored. Our study aims at clarifying the basic geological conditions such as the source and reservoir rocks and reconstructing the dynamic processes of hydrocarbon accumulations (burial, thermal, hydrocarbon generation, expulsion, migration pathways and accumulation histories) in the southern part (Chuditch field) and northern (Sunset-Loxton Shoals field) of the Sahul Platform.

\section{Geological Setting}

The Sahul Platform is a large northeast trending basement high comprising tilted fault blocks and horsts in the northern Bonaparte Basin. The structural evolution, geological history and stratigraphy of the northern Bonaparte Basin have been described by [10] [11]. The Sahul platform is divided into the Troubadour High in the east, where basement lies at approximately $3000 \mathrm{~m}$, and the Kelp High in the west, where basement is interpreted to be significantly deeper [12]. The Troubadour High is a large culmination on the eastern Sahul Platform and was a prominent feature from Permo-Triassic through to recent times. The High is bounded to the south by the Malita Graben, to the east by the Calder Graben, to the southwest by the Sikitan Syncline. The southern boundary of the Sahul Platform is marked by northeast-striking Mesozoic normal faults showing displacement 
down into the Malita and Calder graben, creating a series of prominent blocks and terraces (Figure 1). The Sahul Platform was originally part of a broad, northeast-trending, Late Paleozoic sag basin. Following Early Jurassic rifting, the platform became a depocentre for non-marine and marginal to shallow series of narrow, confined depocentres (Malita Graben and Sahul Syncline) to the south and west of the elevated Sahul Platform. Upper Jurassic and Lower Cretaceous sediments are absent or are mainly confined to these depocentres, and both consist of thin, condensed marine mudstones across the Sahul Platform and Troubadour Terrace. The Sikitan Syncline is NE-SW localized depression of some $1500 \mathrm{Km}^{2}$ on the Sahul Platform. The main period of subsidence in the syncline has been from the Late Miocene to Recent however, the feature overlies a similar Paleozoic trend. Late Miocene to Pliocene convergence (collision) of the Australia-India Plate and the Southeast Asian microplates resulted in flexural down-warp of the Timor Trough to the north, and generation of the Kelp High and Troubadour High faulted anticlinal structures. Collision tectonics, which continue to the present day, rejuvenate Jurassic normal faults and produce a new set of normal faults with a dominant east-northeast strike. Many structural closures in the region were formed or modified by this tectonism.

The Late Permian carbonates Hyland Bay Subgroup [13] overlying granitic basement is the oldest unit intersected by drilling on the northern margin of the Sahul Platform. Late Permian to Early Triassic, marine siltstones and shales of the Mount Goodwin Subgroup [14] overlie the Hyland Bay Formation. Deposition of the Triassic Sahul Group (a mixed clastic-carbonate succession) followed. A Late Triassic marine regression, induced in part by regional uplift associated with the Fitzroy compressional movement, culminated in the deposition of fluvio-deltaic red beds (Nome and Malita Formations). A transgression in the Early to Middle Jurassic deposited a thick fluvio-deltaic to marine succession (Plover Formation) over the area. These units form the petroleum reservoirs and source rocks in the Sunset-Loxton Shoals and Chuditch gas fields. The Plover Formations reservoirs are interpreted to be Bathonian in age in the Sunset-Loxton Shoals and Chuditch fields (Figure 2). The Plover Formation overlain by transgressive shallow marine silty claystone of the Callovian to Oxfordian section of Flamingo Group is known as the Elang (Laminaria) Formation. The Late Jurassic to earliest Cretaceous age Flamingo Group (Frigate) onlaps the breakup unconformity surface is dominated by marine claystone. The distribution areal of the Flamingo Group and its potential as an exploration target on this part of the Sahul Platform remains uncertain, as a number of hiatuses associated with continental breakup are evident in the Flamingo Group succession on the Troubadour High. The Bathurst Island Group comprises a number of distinct sequences. The oldest unit is the Echuca Shoals Formation, overlying the Intra-Valanginian Disconformity and consisting of condensed glauconitic claystones and siltstones (Valanginian to Barremian). The Aptian Disconformity is a strong seismic event, separating the Echuca Shoals from the Darwin (Aptian to Early Albian) condensed calcareous marl, claystone and calcilutite unit deposited at the peak of the cretaceous transgression. The overlying Wangarlu, Vee, Turnstone and Puffin formations, consisting of claystones, marls, calcilutites, calcareous claystones and sandstones (Late Albian to Maastrichtian), were deposited in a marine shelf to slope environment. The Johnson Formation (Paleocene) and the Hibernia Formation (Eocene) consist mainly of calcilutites with associated dolomites, cherts and claystone streaks. The Cartier Formation (Oligocene) is composed of calcareous claystones and marls. The Oliver Formation (Miocene) exhibits continuous carbonate deposition with a pronounced unconformity at the top of the Miocene section related to the collision of the Australian and Southeast Asian plates. The Barracouta Formation (Pliocene to Recent) consists of active margin carbonates unconformably overlying the Miocene.

\section{Materials and Methods}

\subsection{Materials and Input Parameters}

Data for assessment of oil and gas accumulation were collected from the wells Loxton Shoals 1, Sunset 1, and Chuditch 1 in the Sahul Platform and Heron 1 in the Malita Graben. Data required to run the BasinMod 1-D comprised the top and base wellbore depths, present thicknesses of each stratigraphic unit, the lithology mixes data are derived from composite well logs (Table 1). The Biostratigraphy determinations were derived from the ditch cuttings, sidewall cores and conventional cores that were washed, separated and analyzed for micro fauna (Foraminifera) and flora (Spores and Pollens). These were done to attribute an age to each studied interval. Results of rock-eval pyrolysis analyses by Geotechnical Services Pty Ltd in the three wells of the study area and by Northern Territory Geological Survey in the well Heron 1 including total organic carbon content (TOC), and organic thermal indicators include measured vitrinite reflectance values by Keiraville Konsultants Pty. Ltd in the 
Table 1. Geological layers, top and base depths for the wells Sunset 1, Loxton Shoals 1, Chuditch 1 in the Sahul Platform and Heron 1 in the Malita Graben and lithology used as input parameters for the BasinMod 1-D. Lithological data were compiled from their composite well logs.

\begin{tabular}{|c|c|c|c|c|c|c|c|c|}
\hline Well & Sunset 1 & & Loxton Sho & & Chuditc & h 1 & Heron 1 & \\
\hline Formation & Lithology & $\begin{array}{c}\text { Top } \\
\text { Depth } \\
\text { (m RT) }\end{array}$ & Lithology & $\begin{array}{c}\text { Top } \\
\text { depth } \\
(\mathrm{m} \mathrm{RT})\end{array}$ & Lithology & $\begin{array}{c}\text { Top } \\
\text { depth } \\
\text { (m RT) }\end{array}$ & Lithology & $\begin{array}{l}\text { Top depth } \\
\text { (m RT) }\end{array}$ \\
\hline Barracouta & $100 \%$ limestone & 264 & $100 \%$ limestone & 315 & $\begin{array}{c}100 \% \\
\text { limestone }\end{array}$ & 89 & $\begin{array}{c}\text { Similarly } \\
\text { Oliver }\end{array}$ & 50.3 \\
\hline Oliver & 100\% limestone & 523 & $100 \%$ limestone & - & $\begin{array}{c}100 \% \\
\text { limestone }\end{array}$ & 318 & $\begin{array}{c}2 \% \text { siltstone }+ \\
50 \% \text { shale }+40 \% \\
\quad \text { limestone } \\
+8 \% \text { dolomite }\end{array}$ & 198 \\
\hline Cartier & $\begin{array}{c}25 \% \text { shale }+70 \% \\
\text { limetone }+5 \% \\
\text { dolomite }\end{array}$ & 1017 & $100 \%$ limestone & - & - & - & - & - \\
\hline Hibernia & $\begin{array}{c}25 \% \text { shale }+75 \% \\
\text { limetone }\end{array}$ & 1144 & $100 \%$ limestone & 1305 & $\begin{array}{c}25 \% \\
\text { shale }+75 \% \\
\text { limestone }\end{array}$ & 713 & $\begin{array}{l}\text { 15\% sandstone } \\
+5 \% \text { siltstone } \\
\text { + } 5 \% \text { shale } \\
+50 \% \text { limestone } \\
+25 \% \text { dolomite }+\end{array}$ & 533 \\
\hline Johnson & $\begin{array}{l}25 \% \text { shale }+ \\
75 \% \text { limetone }\end{array}$ & 1443 & $\begin{array}{l}2.5 \% \text { sandstone }+ \\
2.5 \% \text { siltstone } \\
+15 \% \text { shale } \\
+80 \% \text { limestone }\end{array}$ & 1435 & $\begin{array}{c}25 \% \\
\text { shale }+75 \% \\
\text { limestone }\end{array}$ & 1128 & 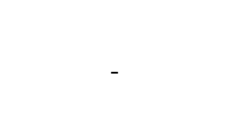 & - \\
\hline $\begin{array}{l}\text { Puffin, Turn- } \\
\text { stone }\end{array}$ & - & - & - & - & $\begin{array}{l}\text { 65\% shale } \\
+35 \% \\
\text { limestone }\end{array}$ & 1598 & $\begin{array}{l}\text { 35\% sandstone } \\
+4 \% \text { siltstone } \\
\text { + } 55 \% \text { shale } \\
+4 \% \text { limestone } \\
+3 \% \text { dolomite }\end{array}$ & 1028 \\
\hline Vee & $\begin{array}{c}\text { 5\% siltstone } \\
+5 \% \text { shale } \\
+90 \% \text { limestone }\end{array}$ & 1521 & $\begin{array}{c}5 \% \text { shale }+ \\
95 \% \text { limestone }\end{array}$ & 1556 & $\begin{array}{c}35 \% \\
\text { shale }+65 \% \\
\text { limestone }\end{array}$ & 1766 & $\begin{array}{l}\text { 10\% sandstone } \\
+2 \% \text { siltstone } \\
+75 \% \text { shale } \\
+8 \% \text { limestone } \\
+5 \% \text { dolomite }\end{array}$ & 1500 \\
\hline Wangarlu & $\begin{array}{c}\text { 1.57\% siltstone }+ \\
\text { 97.80\% shale } \\
+0.63 \% \text { limestone }\end{array}$ & 1756 & $\begin{array}{l}50 \% \text { siltstone } \\
+50 \% \text { shale }\end{array}$ & 1736.5 & $100 \%$ shale & 1972 & $\begin{array}{c}\text { 70\% shale } \\
+30 \% \text { limestone }\end{array}$ & 2500 \\
\hline Jamieson & - & - & $\begin{array}{c}\text { 7.5\% shale } \\
+92.5 \% \text { limestone }\end{array}$ & 2074 & - & - & & - \\
\hline Darwin & $100 \%$ shale & 2091 & $\begin{array}{l}\text { 6.25\% sandstone } \\
+6.25 \text { siltstone } \\
+11.25 \text { shale } \\
+76.25 \text { limestone }\end{array}$ & 2096 & $\begin{array}{l}25 \% \text { shale } \\
\quad+75 \% \\
\text { limestone }\end{array}$ & 2894 & $\begin{array}{l}\text { 3\% siltstone } \\
+70 \% \text { shale } \\
+20 \% \text { limestone } \\
+7 \% \text { dolomite }\end{array}$ & 2657 \\
\hline $\begin{array}{l}\text { Echuca } \\
\text { Shoals }\end{array}$ & $100 \%$ shale & 2122 & - & - & $100 \%$ shale & 2905.5 & $\begin{array}{l}\text { 2\% siltstone } \\
+85 \% \text { shale } \\
+13 \% \text { limestone }\end{array}$ & 3200 \\
\hline $\begin{array}{l}\text { Flamingo } \\
\text { (upper } \\
\text { frigate } \\
\text { shale) }\end{array}$ & - & - & - & - & $\begin{array}{c}65 \% \\
\text { sandstone }+ \\
35 \% \text { shale }\end{array}$ & 2910 & Similarly Cleia & 3500 \\
\hline $\begin{array}{l}\text { Cleia } \\
\text { (lower } \\
\text { frigate } \\
\text { shale) }\end{array}$ & - & - & - & - & - & - & $\begin{array}{l}\text { 6.9\% sandstone } \\
+0.1 \% \text { siltstone } \\
+\quad 78.3 \% \text { shale } \\
+14.7 \% \text { limestone }\end{array}$ & \\
\hline $\begin{array}{c}\text { Elang, } \\
\text { Laminaria }\end{array}$ & $100 \%$ shale & 2130 & $\begin{array}{l}26 \% \text { siltstone } \\
+74 \% \text { shale }\end{array}$ & 2100 & - & - & - & - \\
\hline Plover & $\begin{array}{c}59.89 \% \\
\text { sandstone }+23.02 \% \\
\text { siltstone }+17.09 \% \\
\text { shale }\end{array}$ & 2155 & $\begin{array}{c}\text { 30.94\% sandstone } \\
+30.69 \% \text { siltstone } \\
+32.11 \% \text { shale } \\
\text { + } 2.26 \text { limestone }\end{array}$ & 2114.50 & $\begin{array}{c}60 \% \\
\text { sandstone } \\
+35 \% \text { shale } \\
+5 \% \text { coal }\end{array}$ & 2919 & - & - \\
\hline $\begin{array}{c}\text { Base } \\
\text { depth (m) }\end{array}$ & & 2420 & & 2330 & & 3035 & & 4209 \\
\hline
\end{tabular}

Where: - is no data, RT is Rotary Table. 


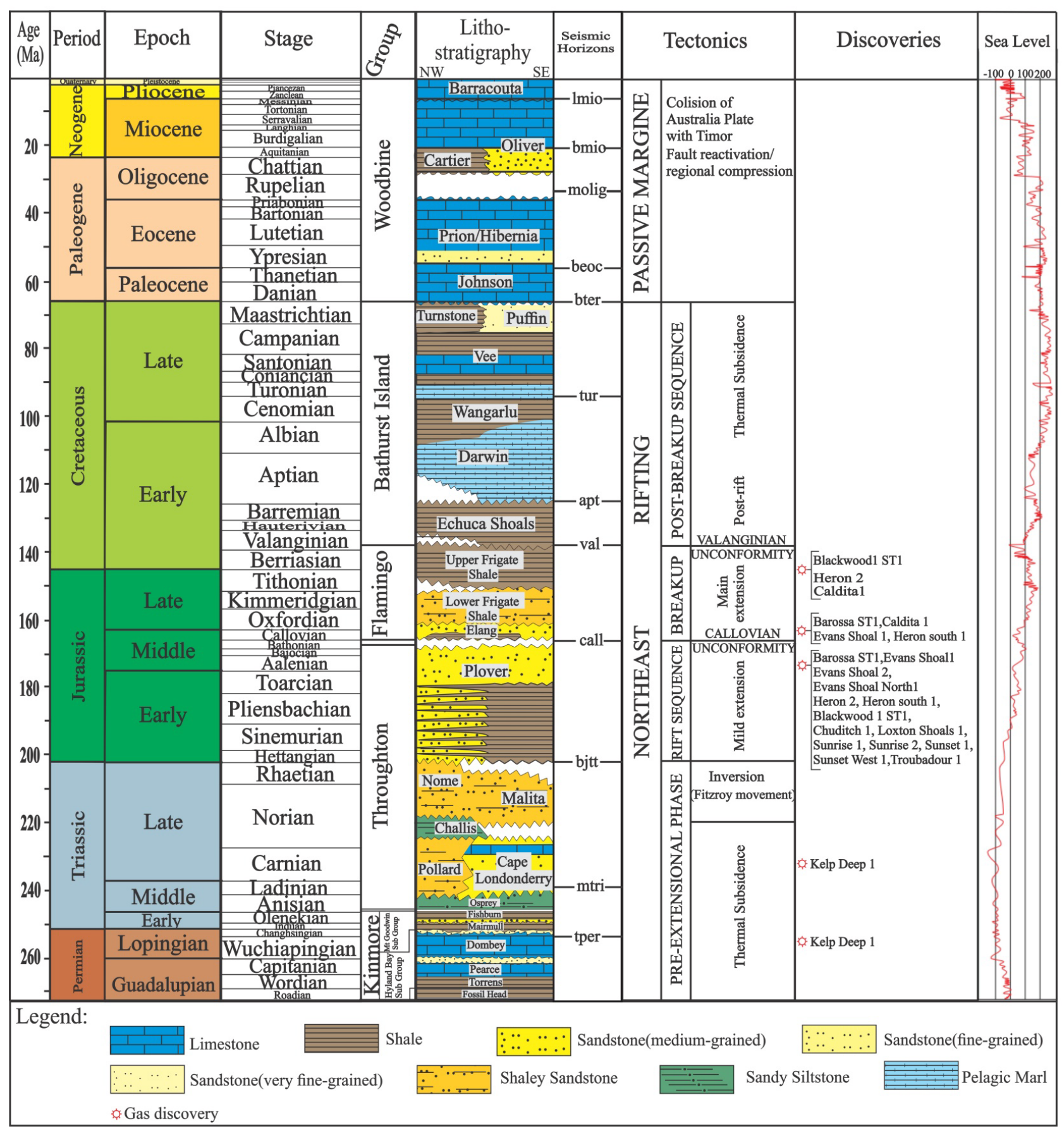

Figure 2. Stratigraphy, tectonics, and petroleum discoveries of the northern Bonaparte Basin, Australia, based on the Bonaparte Basin Biozonation and Stratigraphy Chart 33 (Kelman et al., 2014), showing the short term sea level used for burial history modelled. Geologic Time Scale after Gradstein et al. (2012). Upper Frigate = Flamingo and Lower Frigate = Cleia. Petrel Formation $=$ Frigate (Flamingo and Cleia) Formation equivalent to the "Petrel A and B" of ARCO (1971b), or "Members A and B" of Hughes (1978).

three wells of the study area and by Robertson Research in the well Heron 1 (Table 2); kerogen types, the location of wells, the measurements of porosity and permeability values from the core samples and well-log data; the water-sediment interface temperatures were measured according to [15]; measured temperatures from Drill Stem Test (DST) and subsurface bottom hole temperatures (BHTs) through time, the short term sea level proposed by [16]; geologic time scale 1989 Harland; the density of asthenosphere $(\rho m)$ and water $(\rho w)$ are $3.40 \mathrm{~g} / \mathrm{cm}^{3}$ and 
$1.03 \mathrm{~g} / \mathrm{cm}^{3}$, respectively; all mixed parameters, the initial porosity, reciprocal and exponential compaction factors, the matrix density, matrix thermal conductivity, and matrix heat capacity are adopted from the default values in BasinMod Software package. The input data for 2-D BasinMod included 1-D well databases, the Seismic Line N11606 (Figure 3), map coordinates, reference location of all data including faults, names and age ranges of all layers, lithologic characteristics of facies within the layers. The 3-D BasinMod linked the previous 1-D model and calculated the expulsion and migration history by using a two-phase Darcy equation. It required additional input of relative permeability functions, petroleum density and viscosity and capillary pressures.

\subsection{Methods}

\subsubsection{One-Dimensional Modeling}

One-dimensional modeling of a single well using BasinMod 1-D was performed to reconstruct the burial, thermal, hydrocarbon generation and expulsion histories. Further, it determined the subsidence and sedimentation rates, as well as maturation parameters, such as the time of onset, peak, and end of oil and wet gas generation and expulsion.

An Exponential Equation of [17] for mechanical compaction that relates porosity to depth was used for porosity calculation as follows:

$$
\phi=\phi_{o} \exp ^{(-k z)}
$$

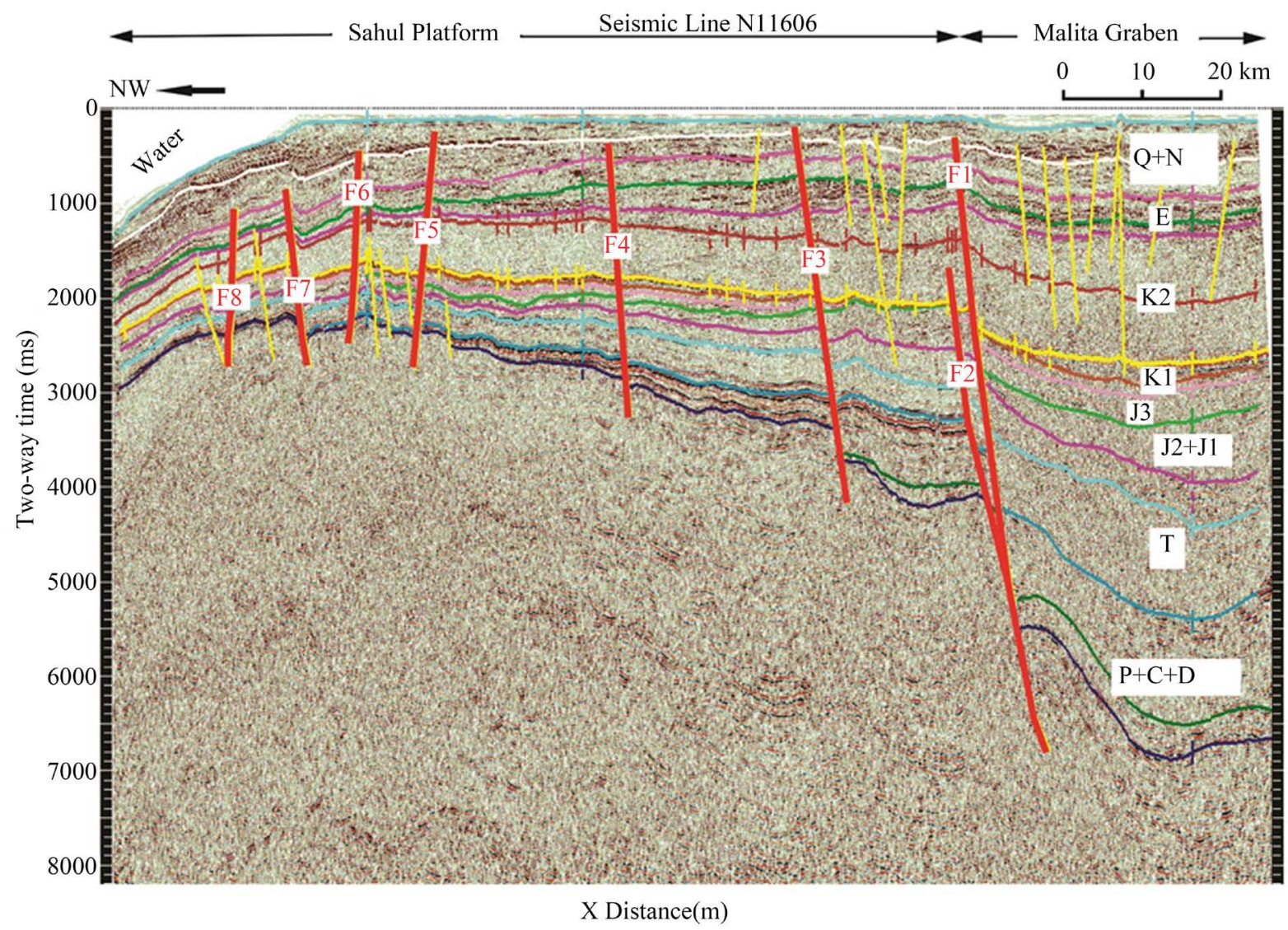

Figure 3. Two-dimensional Seismic Line N11606. Location shown in Figure 1. The key stratigraphic horizons indicated in black capital letters: Q + N = Oliver, Barracouta and Alaria formations, E = Johnson, Hibernia and Cartier formations; $\mathrm{K}_{2}=$ Vee, Turnstone and Puffin formations; $\mathrm{K}_{1}=$ Echuca Shoals, Darwin and Wangarlu formations; $\mathrm{J}_{3}=$ Elang (Laminaria)and Frigate (Cleia and Flamingo) formations; $\mathrm{J}_{2}+\mathrm{J}_{1}=$ Plover Formation; $\mathrm{T}=$ Mount Goodwin Subgroup, Pollard, Cape Londonderry, Challis, Nome, and Malita formations and P $+\mathrm{C}+\mathrm{D}=$ Fossil Head Formation, and Hyland Bay Subgroup. The faults are indicated in red capital letters: F1 to F8. 
Table 2. Mean Ro\% values and Rock-Eval Pyrolysis Analyses parameters for the wells Loxton Shoals 1, Sunset 1and Chuditch 1 in the Sahul Platform and Heron 1 in the Malita Graben source rock samples.

\begin{tabular}{|c|c|c|c|c|c|c|c|c|}
\hline Well Name & Depth (mRT) & Formation & Lithology & TOC (wt\%) & $\mathrm{S} 1+\mathrm{S} 2$ (mg/g) & HI (mg/g) & $\operatorname{Tmax}\left({ }^{\circ} \mathrm{C}\right)$ & Mean Ro\% \\
\hline $\begin{array}{l}\text { Loxton } \\
\text { Shoals } 1\end{array}$ & $2127-2308$ & Plover & Claystone & $\begin{array}{c}0.68-2.49 \\
1.57(8)\end{array}$ & $\begin{array}{c}0.51-3.55 \\
1.91(8)\end{array}$ & $\begin{array}{l}47-149 \\
80(8)\end{array}$ & $\begin{array}{c}447-499 \\
463(8)\end{array}$ & $\begin{array}{l}1-1.46 \\
1.19(4)\end{array}$ \\
\hline Sunset 1 & 2162.30 - 2334 & Plover & Shale & $\begin{array}{c}1.60-36.50 \\
3.99(27)\end{array}$ & $\begin{array}{c}1.92-80.44 \\
9.17(27)\end{array}$ & $\begin{array}{c}102-396.77 \\
202.86(27)\end{array}$ & $\begin{array}{c}431-446 \\
439.77(27)\end{array}$ & $\begin{array}{c}0.55-0.84 \\
0.66(27)\end{array}$ \\
\hline \multirow[t]{3}{*}{ Chuditch 1} & 2905.9 - 2909 & $\begin{array}{l}\text { Echuca } \\
\text { Sholas }\end{array}$ & Claystone & $\begin{array}{c}1.53-5.50 \\
2.91(3)\end{array}$ & $\begin{array}{c}2.19-13.15 \\
8.59(3)\end{array}$ & $\begin{array}{c}39.22-199.45 \\
113.67(3)\end{array}$ & $\begin{array}{l}423-452 \\
441.67(3)\end{array}$ & $\begin{array}{c}0.84-0.90 \\
0.87(2)\end{array}$ \\
\hline & 2914.9 - 2918 & $\begin{array}{c}\text { Flamingo } \\
\text { (Upper } \\
\text { Frigate) }\end{array}$ & Claystone & $\begin{array}{c}0.93-1.98 \\
1.46(2)\end{array}$ & $\begin{array}{c}3.47-4.44 \\
3.96(2)\end{array}$ & $\begin{array}{c}132.32-153.76 \\
143.04(2)\end{array}$ & $\begin{array}{l}355-452 \\
403.5(2)\end{array}$ & 0.92 \\
\hline & $2922.65-2944.09$ & Plover & Claystone & $\begin{array}{l}2.65-14.76 \\
5.80(4)\end{array}$ & $\begin{array}{c}3.80-21.22 \\
8.24(4)\end{array}$ & $\begin{array}{c}109.55-128.30 \\
119.89(4)\end{array}$ & $\begin{array}{l}452-457 \\
453.25(4)\end{array}$ & $\begin{array}{c}0.96-1.14 \\
1.01(5)\end{array}$ \\
\hline \multirow[t]{2}{*}{ Heron 1} & $3207-3499.20$ & $\begin{array}{l}\text { Echuca } \\
\text { Shoals }\end{array}$ & Claystone & $\begin{array}{c}0.34-4.45 \\
2.05(31)\end{array}$ & $\begin{array}{c}0.25-7.82 \\
1.63(24)\end{array}$ & $\begin{array}{c}18.15-103.07 \\
50.20(24)\end{array}$ & $\begin{array}{l}347-432 \\
411.5(18)\end{array}$ & $\begin{array}{c}0.56-2.01 \\
1.32(5)\end{array}$ \\
\hline & 3505.20 - 4186 & $\begin{array}{c}\text { Petrel } \\
\text { (Frigate) }\end{array}$ & Shale & $\begin{array}{c}0.90-26.40 \\
3.71(53)\end{array}$ & $\begin{array}{c}0.26-23.90 \\
2.17(29)\end{array}$ & $\begin{array}{c}15.29-233.46 \\
64.78(29)\end{array}$ & $\begin{array}{c}328-493 \\
407.41(29)\end{array}$ & $\begin{array}{c}1.08-3.29 \\
2.02(8)\end{array}$ \\
\hline
\end{tabular}

where TOC is the total organic matter carbon content (wt\%), Ro\% is a vitrinate reflectance; HI is hydrogen index (mg HC/g TOC); Tmax ( ${ }^{\circ} \mathrm{C}$ ) measures thermal maturity and corresponds to the Rock-Eval pyrolysis oven temperature $\left({ }^{\circ} \mathrm{C}\right.$ ) maximum $\mathrm{S}_{2}$ generation; S1 + S2 represents the total amount of petroleum that might be generated from a rock in mg HC/g rock (S1 is free hydrocarbon and S2 is the hydrocarbon generation potential of the source rock); Minimum value-Maximum value/Average (number of samples).

where, $\phi$ is porosity, $\phi_{0}$ is initial porosity, $K$ is compaction factor adjusted for varying compressibilities of different lithologies, and $z$ is the depth (m).

The Mathematical method comprises the equations of backstripping and tectonic subsidence [18], was used to reconstruct the burial history:

$$
\begin{gathered}
D t=\left[S \frac{\left(\rho_{m}-\rho_{s}\right)}{\left(\rho_{m}-\rho_{w}\right)}-\Delta S L \frac{\rho_{w}}{\left(\rho_{m}-\rho_{w}\right)}\right]+\left(W_{d}-\Delta S L\right) \\
\rho_{s}=\frac{\sum_{i}\left[\phi_{i} \rho_{w}+\left(1-\phi_{i}\right) \rho_{s g i}\right] S_{i}}{S}
\end{gathered}
$$

where: $D t$ is the amount of tectonic subsidence (water column (m) in past time).

$S$ is the total stratigraphic thickness of the sediment column corrected for compaction (m).

$\rho_{s}$ is the average density of the sediment stratigraphic column $\left(\mathrm{g} / \mathrm{cm}^{3}\right)$.

$W_{d}$ is the paleo-water depth (m).

$\Delta S L$ is the relative increment for eustatic sea-level variation (m).

$\rho_{m}$ is the density of asthenosphere $\left(\mathrm{g} / \mathrm{cm}^{3}\right)$.

$\rho_{w}$ is the density of water $\left(\mathrm{g} / \mathrm{cm}^{3}\right)$.

$\phi_{i}$ is the porosity of stratigraphic unit $i$ (dimensionless).

$\rho_{s g i}$ is the grain density of stratigraphic unit $i\left(\mathrm{~g} / \mathrm{cm}^{3}\right)$.

$S_{i}$ is the thickness of stratigraphic unit $i$ after compaction correction (m).

The transient heat flow equation of BasinMod 1-D was used to describe the thermal conduction and convention of the heat flow, assuming that the heat transfer in 1-D was by vertical conduction using the following equation:

$$
\begin{gathered}
\frac{\mathrm{d} T(x, t)}{\mathrm{d} t}=\frac{\mathrm{d}}{\mathrm{d} x}\left(\alpha(x) \frac{\mathrm{d} T}{\mathrm{~d} x} Q\right) \\
\alpha(x)=\frac{k}{\rho c}
\end{gathered}
$$

where $\alpha$ is thermal diffusivity, $T$ is temperature $(\mathrm{K}), k$ is thermal conductivity $\left(\mathrm{W} / \mathrm{m} \times{ }^{\circ} \mathrm{C}\right), c$ is heat capacity 
$\left(\mathrm{kJ} / \mathrm{m}^{3} \times{ }^{\circ} \mathrm{C}\right), t$ is time (Ma), $\rho$ is density $\left(\mathrm{g} / \mathrm{cm}^{3}\right), Q$ is source heat term $(\mathrm{KJ})$ and $x$ is depth $(\mathrm{m})$.

The total organic carbon cotent (TOC) versus potential yield (S1 + S2) was used to determine the potential generating hydrocarbon. Modified [19] by [20], temperature maximum (Tmax) versus hydrogen index (HI) for the characterisation of kerogen types, and measured mean Ro\% versus Depth for thermal maturity.

Modified Kozeny-Carman Model for Permeability was used for fluid flow calculation as follows:

$$
K=\left\{\begin{array}{l}
\frac{0.2 \phi^{3}}{S_{0}^{2}(1-\phi)^{2}}(\phi \geq 0.1) \\
\frac{20 \phi^{5}}{S_{0}^{2}(1-\phi)^{2}}(\phi \prec 0.1)
\end{array}\right.
$$

where, $K$ is permeability (millidarcy-md), $S_{0}$ is specific surface area of the rock $\left(\mathrm{m}^{2}\right)$, and $\phi$ is porosity (dimensionless-\%).

Coupled fluid flow equation integrated with mass conservation law equation of [21] and [22] was used for pressure modeling:

$$
\begin{gathered}
-\nabla \rho V=\frac{\partial}{\partial z}(\rho \phi)+q \\
v=-\frac{K}{\mu} \frac{\partial P}{\partial L}
\end{gathered}
$$

where $\rho$ is density, $\phi$ is porosity, $q$ is source term, $v$ is the velocity, $K$ is permeability, $\mu$ is viscosity, $\frac{\partial P}{\partial L}$ is excess pressure gradient. In this equation (8), the fluid flow rate is proportional to the excess fluid pressure gradient, rock permeability, and fluid viscosity. The conservation law requires that during fluid flow modeling, the mass is always conserved.

The thermal maturity of organic matter was calculated by the Easy Ro\% model [23]. A certain quantity of petroleum must be generated to fill the pore space of the source rock to migrate out of it [24]. When the pore space of source rocks is saturated with hydrocarbons to a threshold, hydrocarbons beyond this threshold will be expelled, and then petroleum primary migration occurs [25]. The saturated threshold is set to 0.02. The expelled hydrocarbon then begins secondary migration along carrier beds driven by excess pressure, buoyancy pressure, and capillary pressure [26] [27].

\subsubsection{Two-Dimensional Modeling}

Two-dimensional modeling was applied to scan input 2-D seismic line N11606 that crossed the study area in the northwest-southeast trend and comprising eight stratigraphic horizons that best depicted the structure, maturity, and generation histories. Whereas Two-Way-Time (milliseconds) conversions to depths in meters was done outside of BasinMod 2-D.

The transient heat flow equation of BasinMod 2-D was also used to describe the lateral and vertical thermal conduction and convection of the heat flow of the study area.

\subsubsection{Three-Dimensional Modeling}

The migration modeling was accomplished by Basin View and Basin Flow software using saturation method with threshold value of $2 \%$. The direction of migration pathways and the effects of hydrodynamics were obtained by mapping the depth from sea level to the top surface of the carrier bed assuming that they were normal to the contours of the hydrocarbon potential surface. Further, there was potential for hydrocarbon to accumulate within closure contours around lows on the potential surface. The hydrocarbon potential (HФ) along a structure surface was calculated based on three physical parameters that affect the migration of hydrocarbons in the subsurface: (a) hydrocarbon buoyancy, (b) hydrodynamic drive and (c) capillary threshold pressure as follows:

$$
H \Phi=H_{\text {hydrocarbon }} \times G=\left(H_{\text {buoy }}+H_{\text {hydro }}+H_{\text {cap }}\right) \times G
$$

where, $H_{\text {hydrocarbon }}$ is the hydrocarbon head, $H_{\text {buoy }}$ is the hydrocarbon buoyancy head, $H_{\text {hydro }}$ is the hydrodynamic head, $H_{\text {cap }}$ is the head due to capillary threshold pressure, and $G$ is the gravitational constant $\left(9.81 \mathrm{~m} / \mathrm{s}^{2}\right)$. In this 
paper, migration pathways were modelled based on Equation (9) along a structure surface without taking into attention of the influence of faults sealing ability and porosity and permeability heterogeneity of the carrier beds.

The hydrocarbon buoyancy head is calculated at each grid nod after [28]:

$$
H_{\text {buoy }}=-\left[\left(\rho_{w}-\rho_{h c}\right) / \rho_{h c}\right] \times Z_{\text {carrier }}
$$

where, $\rho_{w}$ is the density of water, $\rho_{h c}$ is the density of hydrocarbon, and $Z_{\text {carrier }}$ is the elevation of the carrier bed. The hydrodynamic head model of [29] can be calculated as follow:

$$
H_{\text {hydro }}=\left[\left(Z_{\text {carrier }}+P_{\text {pore }}\right) /\left(\rho_{w} \times G\right)\right] \times\left(\rho_{w} / \rho_{h c}\right)
$$

where, $P_{\text {pore }}$ is the pore pressure. The head due to capillary threshold pressure can be written as:

$$
H_{\text {cap }}=P_{\text {cap }} /\left(\rho_{\text {hc }} \times G\right)
$$

where, $P_{\text {cap }}$ is the capillary pressure which is calculated according to the [30] equation:

$$
P_{\text {cap }}=2 \gamma_{h c-w} / r_{t}
$$

where, $r_{t}$ is the pore-throat radius, $\gamma_{h c-w}$ is the interfacial surface tension between hydrocarbons and subsurface pore water which was derived by [31] from data of [32] and [33].

\section{Results and Discussion}

\subsection{Thermal History}

Thermal history is essential to the timing, amount, and composition of generated hydrocarbons [34]. A total of twenty one (21) measured temperatures were obtained from the four wells Loxton Shoals 1 , Sunset 1 , Chuditch 1 , and Heron 1 . The seabed temperature was assumed to be $20^{\circ} \mathrm{C}$. The well Loxton Shoals 1 reached a total depth of $2330 \mathrm{mRT}$ within the Plover Formation, and the calculated extrapolated static bottom hole temperature of $153.30^{\circ} \mathrm{C}$, with temperature gradient of $5.72^{\circ} \mathrm{C} / 100 \mathrm{~m}$. Similarly in the well Sunset 1 reached $2420 \mathrm{mRT}$, and bottom hole temperature of $124.30^{\circ} \mathrm{C}$, with temperature gradient of $4.31^{\circ} \mathrm{C} / 100 \mathrm{~m}$, and in the well Chuditch 1 reached $3035 \mathrm{mRT}, 145^{\circ} \mathrm{C}$ bottom hole temperature, with $3.94^{\circ} \mathrm{C} / 100 \mathrm{~m}$. The well Heron 1 reached a total depth of $4209 \mathrm{mKB}$ within Petrel (Frigate) Formation, and the calculated extrapolated static bottom hole temperature is reported as $183^{\circ} \mathrm{C}$, with a temperature gradient of $3.87^{\circ} \mathrm{C} 100 \mathrm{~m}$. The thermal history identifying the fitness of the measured values and modelled curves of the temperature in our study is shown in Figure 4. The present day heat flow was calculated from sea bottom temperatures, bottom hole temperatures and modelled sediment thermal conductivities. In BasinMod 1-D software, the transient heat flow model can be used to calculate the present-day heat flow. A transient heat flow model was employed to handle the heat transfer in the basin of our study. The modeling results show that the present day heat flow values in the wells Loxton Shoals 1 , Sunset 1 , Chuditch 1, and Heron 1 were 75.81, 59.04, 54, and $57.76 \mathrm{~mW} / \mathrm{m}^{2}$, respectively.

\subsection{Source Rock Richness and Hydrocarbon Generation Potential}

The measurements of TOC and thermal cracking of the organic matter by pyrolysis (S1 and S2 mg HC/g rock) are essential in evaluating source rock richness and hydrocarbon generation potential [35]. Interpretations of Rock-Eval pyrolysis parameters used to assess source rock quality and hydrocarbon generation potential were carried out as stated by the standard guidelines suggested by [36]. The Plover Formation source rock in the well Loxton Shoals 1 was contained eight (8) TOC and S1 + S2 values ranging from 0.68 to 2.49 wt\% with an average of $1.57 \mathrm{wt} \%$ and from 0.51 to $3.55 \mathrm{mg} \mathrm{HC} / \mathrm{g}$ rock with an average of $1.91 \mathrm{mg} \mathrm{HC} / \mathrm{g}$ rock, respectively (Table 2). These values indicated that the Plover Formation source rock was a fair-to-very good source rock with poor-to-fair and an overall poor hydrocarbon generative potential. The Plover Formation source rock in the well Sunset 1 had twenty seven (27) TOC and S1 + S2, which varied from 1.60 to 36.50 wt\% with an average of $3.99 \mathrm{wt} \%$ and from 1.92 to $80.44 \mathrm{mg} \mathrm{HC} / \mathrm{g}$ rock with an average of $9.17 \mathrm{mg} \mathrm{HC} / \mathrm{g}$ rock, respectively. This showed a poor-to-very good source rock with poor-to-very good and an overall good hydrocarbon generating potential. The Echuca Shoals Formation source rock in the well Chuditch 1 comprised three (3) TOC and S1 + S2 ranging from 1.53 to $5.50 \mathrm{wt} \%$ with an average of $2.91 \mathrm{wt} \%$ and from 2.19 to $13.15 \mathrm{mg} \mathrm{HC} / \mathrm{g}$ rock with an 

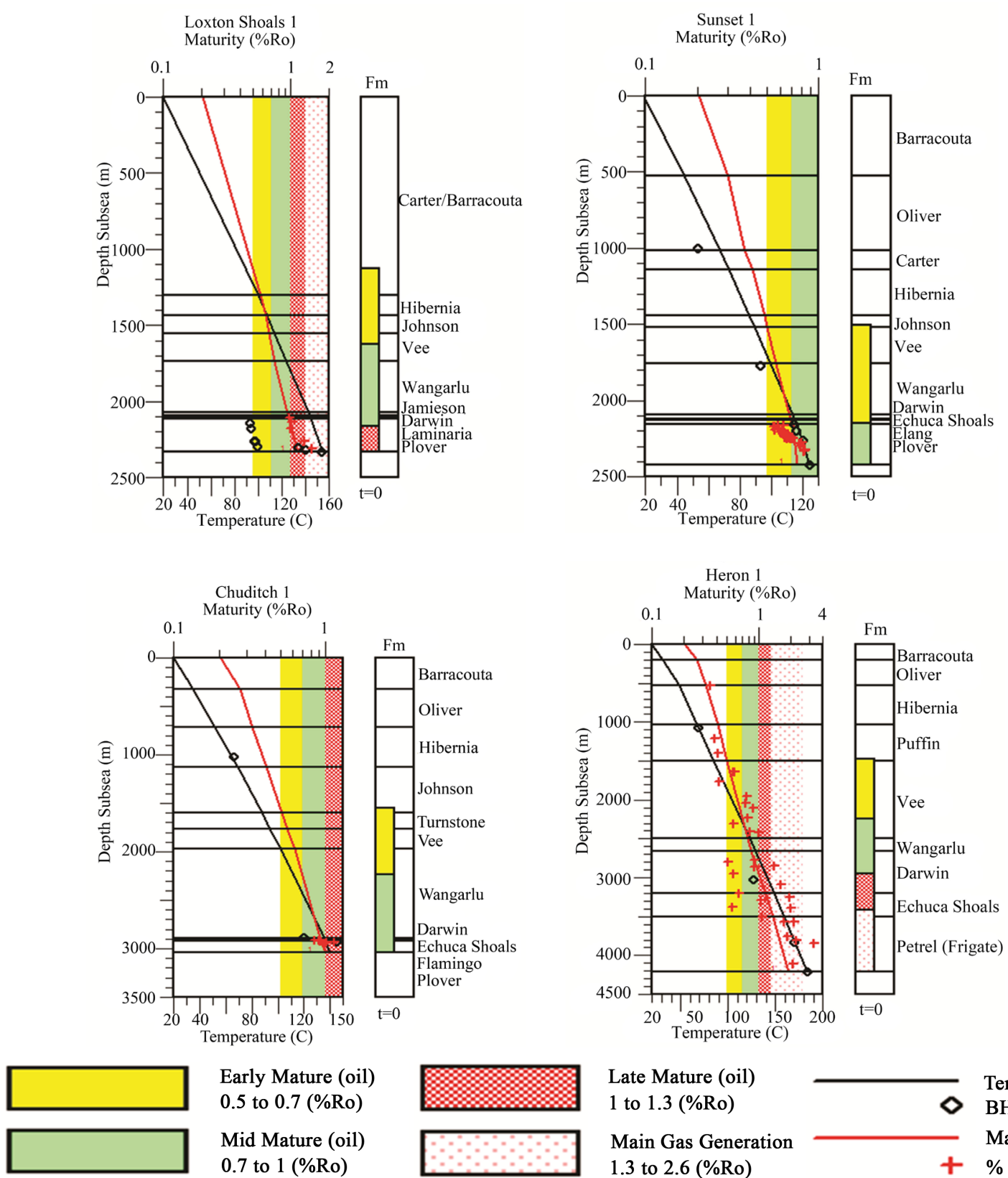

Early Mature (oil) 0.5 to 0.7 (\%Ro)

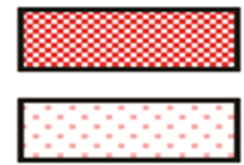

Late Mature (oil) 1 to 1.3 (\%Ro)

Mid Mature (oil) 0.7 to 1 (\%Ro)

Main Gas Generation 1.3 to $2.6(\%$ Ro)

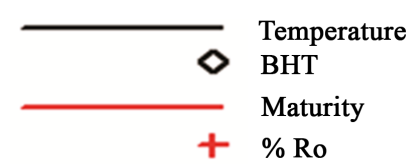

Figure 4. The thermal and maturity histories identifying the fitness of the modelled curves and measured values mean Ro\% and Temperature for the wells Loxton Shoals 1, Sunset 1, Chuditch 1 in the Sahul Platform and Heron1 in the Malita Graben.

average of $8.59 \mathrm{mg} \mathrm{HC/g}$ rock, respectively. This indicated a good-to-very good organic richness with poor-tovery good and an overall good hydrocarbon generating potential. The Flamingo Formation source rock in the same well contained two (2) TOC and S1 + S2 ranging from 0.93 to $1.98 \mathrm{wt} \%$ with an average of $1.46 \mathrm{wt} \%$ and from 3.47 to $4.44 \mathrm{mg} \mathrm{HC/g}$ rock with an average of $3.96 \mathrm{mg} \mathrm{HC} / \mathrm{g}$ rock, respectively. This indicated a fair-togood source rock with a fair hydrocarbon generation potential. In the same well the Plover Formation source rock comprised four (4) TOC and S1 + S2 varying from 2.65 to $14.76 \mathrm{wt} \%$ with an average of $5.80 \mathrm{wt} \%$ and from 3.80 to $21.22 \mathrm{mg} \mathrm{HC/g}$ rock with an average of $8.24 \mathrm{mg} \mathrm{HC} / \mathrm{g}$ rock, respectively. This showed a good-to-very good organic richness with fair-to-very good and an overall fair-to-good hydrocarbon generative potential. The Echuca Shoals Formation source rock in the well Heron 1 had thirty one (31) TOC ranging from 0.34 to $4.45 \mathrm{wt} \%$ with an average of $2.05 \mathrm{wt} \%$, and twenty four (24) S1 + S2 varying from 0.25 to $7.82 \mathrm{mg}$ 
$\mathrm{HC} / \mathrm{g}$ rock with an average of $1.64 \mathrm{mg} \mathrm{HC/g}$ rock. This indicated an overall good-to-very good organic richness with poor-to-good hydrocarbon generative potential. The Petrel (Frigate) Formation source rock in the same well contained fifty three (53) TOC ranging from 0.90 to $26.40 \mathrm{wt} \%$ with an average of $3.71 \mathrm{wt} \%$, and twenty nine (29) S1 + S2 ranging from 0.26 to $23.90 \mathrm{mg} \mathrm{HC/g}$ rock with an average of $2.17 \mathrm{mg} \mathrm{HC/g}$ rock, showed an overall very good source richness with poor-to-very good hydrocarbon generating potential (Figure 5(a)).

\subsection{Source Rock Type}

The source rock type was assessed, based on the modified van Krevelen diagram of Temperature maximum (Tmax) versus Hydrogen Index (HI) (Figure 5(b)). The HI of the shales of the Plover, Frigate (Flamingo and Cleia) and Echuca Shoals formations source rocks in this study was variable from one well to another (Table 2). The Plover Formation source rock in the well Loxton Shoals 1 possessed eight (8) HI, ranging from 47 to 149 mg HC/g TOC with an average of $80 \mathrm{mg} \mathrm{HC/g} \mathrm{TOC,} \mathrm{showed} \mathrm{kerogen} \mathrm{type} \mathrm{III} \mathrm{and} \mathrm{gas-prone.} \mathrm{The} \mathrm{Plover} \mathrm{For-}$ mation source rock in the well Sunset 1 contained twenty seven (27) HI, which ranged from 102 to $396.77 \mathrm{mg}$ HC/g TOC with an average of $202.86 \mathrm{mg} \mathrm{HC/g}$ TOC, indicated Kerogen type II\&III predominantly with gas prone. In the well Chuditch 1, the Echuca Shoals Formation source rock, three (3) HI readings were recorded, which varied from 39.22 to $199.45 \mathrm{mg} \mathrm{HC} / \mathrm{g}$ TOC with an average of $113.67 \mathrm{mg} \mathrm{HC} / \mathrm{g}$ TOC, showed kerogen type III and gas prone. Similarly Flamingo Formation source rock in the same well, two (2) HI readings were recorded, which ranged from 132.32 to $153.76 \mathrm{mg} \mathrm{HC} / \mathrm{g}$ TOC with an average of $143.04 \mathrm{mg} \mathrm{HC} / \mathrm{g}$ TOC and Plover Formation source rock, four (4) HI readings recorded, varied from 109.55 to $128.30 \mathrm{mg}$ HC/g TOC with an average of $119.89 \mathrm{mg} \mathrm{HC/g}$ TOC. The Echuca Shoals Formation source rock in the well Heron 1 comprised twenty four (24) HI, which ranged from 18.15 to $103.07 \mathrm{mg} \mathrm{HC} / \mathrm{g}$ TOC with an average of $50.20 \mathrm{mg}$ HC/g TOC, indicated kerogen type III and gas prone. Likewise the Frigate (Flamingo and Clelia) Formation source rock in the same well contained twenty nine (29) HI, varied from 15.29 to $233.46 \mathrm{mg} \mathrm{HC} / \mathrm{g}$ TOC with an average of $64.78 \mathrm{mg}$ HC/g TOC (Table 2).

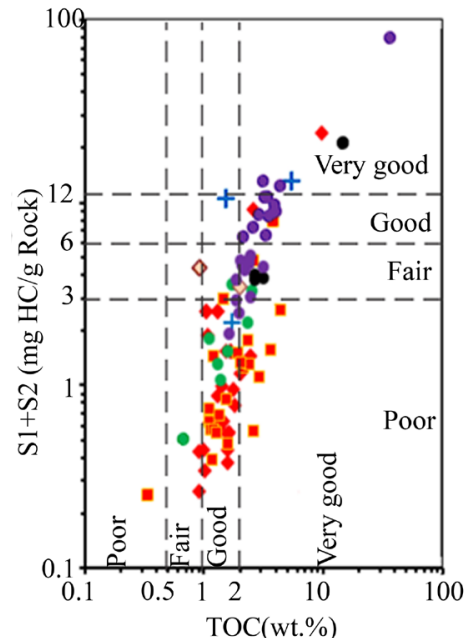

Legend:

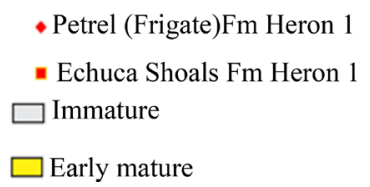

(a)
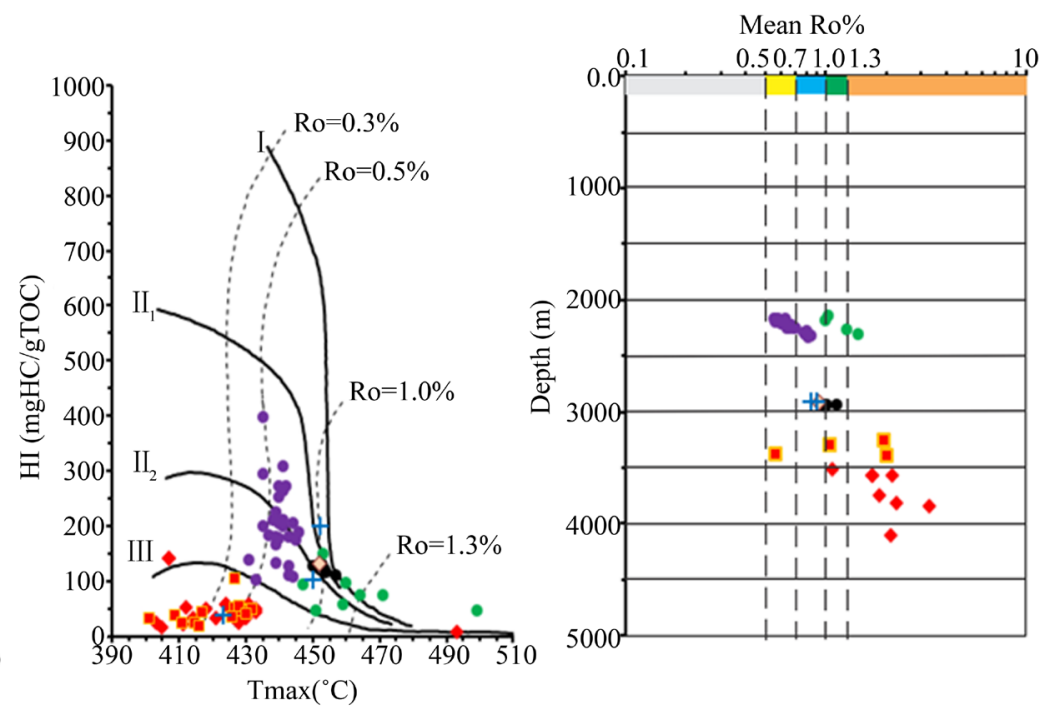

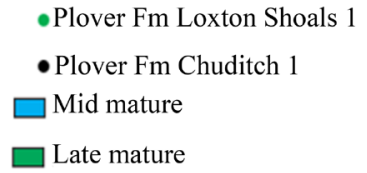

(b)

\begin{abstract}
$\diamond$ Flamingo Fm Chuditch $1 \quad$ बPlover Fm Sunset 1
+ Echuca Shoals Chuditch 1

High mature
\end{abstract} 10

(1)




\subsection{Source Rock Maturity}

The calculated based on Easy Ro\% model [23] using BasinMod 1-D software (Figure 4), measured mean vitrinite reflectance Ro\% values (Figure 5(c)), and the Seismic Line N11606 with BasinMod 2-D (Figure 6) were used to assess the degree of thermal maturity attained by the examined source rocks. The Plover Formation source rock in the well Loxton Shoals 1, four (4) mean Ro readings were recorded, which ranged from $1.00 \%$ to $1.46 \%$, with an average of $1.19 \%$ (Table 2). These values indicated peak oil window to high maturity level with an average of late mature oil widow, corresponding to the depth of 2135 and $2308 \mathrm{~m}$, respectively. The Plover Formation source rock in the well Sunset 1 , twenty seven (27) mean Ro readings were recorded, varying from $0.55 \%$ to $0.84 \%$ with an average of $0.66 \%$. This showed early to mid-mature oil window with an overall mean of middle oil window, corresponding to the depth of 2162.30 and $2334 \mathrm{~m}$, respectively. In the well Chuditch 1 , the Echuca Shoals Formation source rock contained two (2) mean Ro, ranging from $0.84 \%$ to $0.90 \%$ with an average of $0.87 \%$, indicated mid-mature oil window, corresponding to the depth of 2907.5 and $2909 \mathrm{~m}$, respectively, and the Flamingo Formation source rock had one (1) mean Ro value of $0.92 \%$, which indicated mid-mature oil window, corresponding to the depth of 2918 m; whereas the Plover Formation source rock comprised five (5) mean Ro, which varied from $0.96 \%$ to $1.14 \%$ with an average of $1.01 \%$. This showed middle to late mature oil window with an overall mean of peak to late mature oil window, corresponding to the depth of 2922.65 and $2944.09 \mathrm{~m}$, respectively. As for the Echuca Shoals Formation source rock in the well Heron 1, five (5) mean Ro readings were recorded, which ranged from $0.56 \%$ to $2.01 \%$ that have the mean value of $1.32 \%$. This showed different maturity levels, ranging from early to high mature with an overall mean of late to high maturity levels, corresponding to the depth of 3289 and 3390 m, respectively, and the Petrel (Frigate) Formation source rock, eight (8) mean Ro readings were recorded, ranging from $1.08 \%$ to $3.29 \%$ with an average of $2.02 \%$. This indicated late to high mature with an overall mean of high maturity level, corresponding to the depth below $3561 \mathrm{~m}$.

In contrast, the interpretation of the source rocks maturation levels and hydrocarbons generation across in the study area was conducted using the Seismic Line N11606, which is forced by projection of the data from the wells Loxton Shoals 1, Sunset 1, and Chuditch 1 in the Sahul Platform and Heron 1 in the Malita Graben.

The maturity of the source rocks was interpreted to have been initiated at a level of thermal maturity of $0.5 \%$ $0.7 \%$ Ro and concluded at a level of thermal maturity of $1.3 \%-2.6 \%$ Ro. The maturity evolution along the Seismic Line N11606 was described as follows: at 95 Ma the Plover, Flamingo, and Echuca Shoals formations were immatures in the study area and in the center of the Malita Graben, the Echuca Shoals Formation was immature, whereas at the base of the Petrel (Frigate) Formation occurred early mature oil window (Figure 6(a)). At $65 \mathrm{Ma}$, the onset of early mature oil took place at the base of Plover Formation in the north margin, and at the base of Echuca Shoals and Flamingo formations in the south margin of the Study area. The Plover Formation entered mid-mature oil window in the south margin of the study area, and in the center of the Malita Graben, the Echuca Shoals Formation entered late mature oil window and the Petrel (Frigate) Formation wet gas window (Figure 6(b)). At $23.30 \mathrm{Ma}$, the Plover Formation entered mid-mature oil window in the north margin, and at the base of Echuca Shoals and Flamingo formations occurred mid-mature oil window, whereas the Plover Formation entered late mature oil window in the south margin of the study area. The Echuca Shoals Formation entered wet gas window and the later took place at the base of Petrel (Frigate) Formation in the center of the Malita Graben (Figure 6(c)). At the present day, at the base of the Plover Formation occurred middle, late mature oil, and wet gas windows in the north margin, and at the base of Echuca Shoals and Flamingo formations took place mid-mature oil window, however at the base of Plover Formation occurred late mature oil window in the south margin of the study area. In the center of the Malita Graben, at the base of Echuca Shoals and Petrel (Frigate) formations occurred wet gas window (Figure 6(d)). The modeling results were calibrated to the measured mean vitrinite reflectance values for the three wells Loxton Shoals 1 , Sunset 1 and Chuditch 1 of the study area, one well Heron 1 of the Malita Graben and for the Seismic Line N11606 (Figure 4 and Figure 6), and the correspondence between the simulated and the measured values was remarkably good, which indicated that the accuracy was relatively higher for both $1 \mathrm{D}$ and $2 \mathrm{D}$ modeling.

\subsection{Reservoir Properties}

The Plover Formation (Middle Jurassic) is the main reservoir in the Sahul Platform. The lithology of the reservoir comprises of very fine to coarse-grained quartzarenites and sublitharenites that are interbedded with variably 


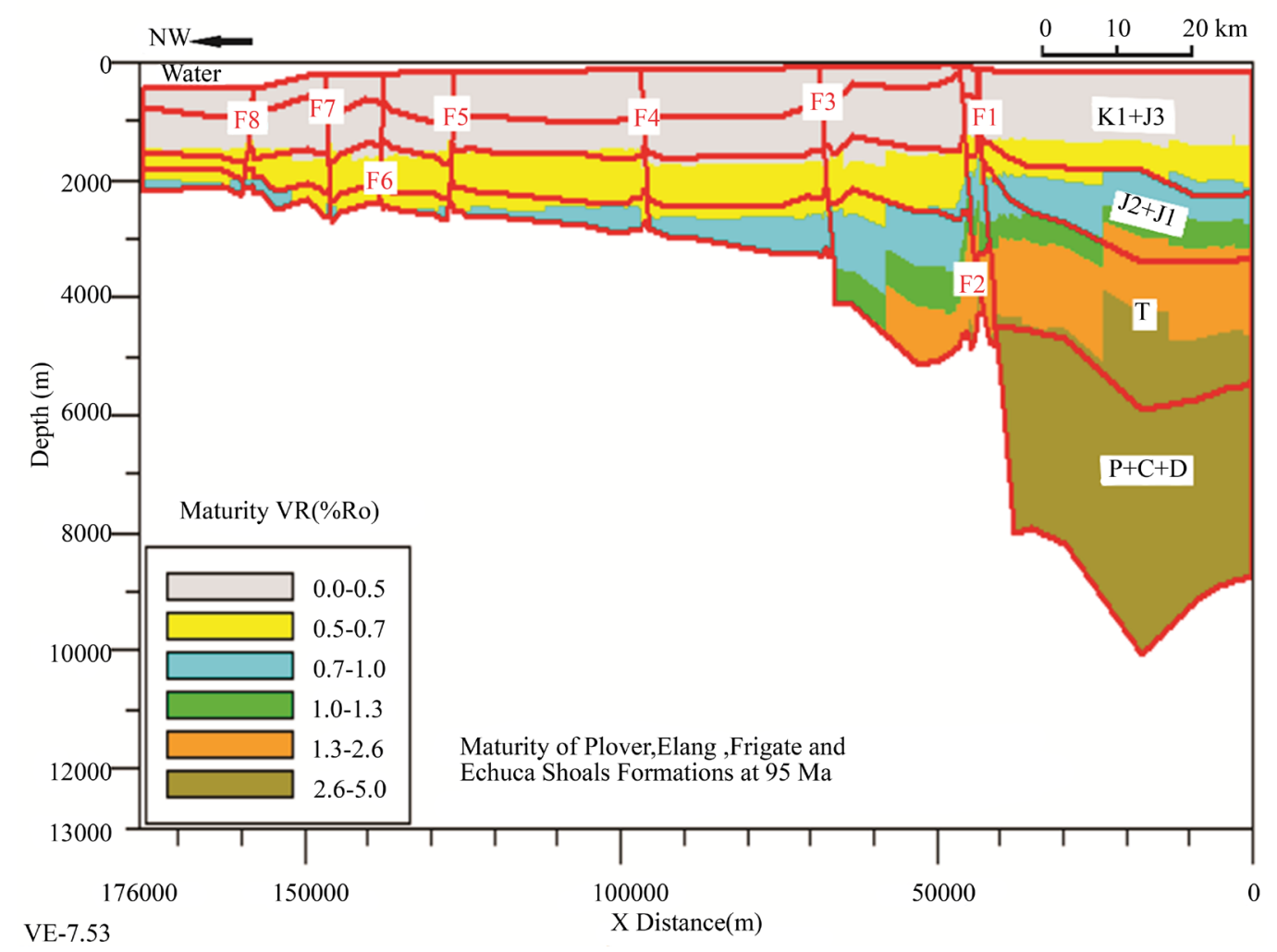

(a)

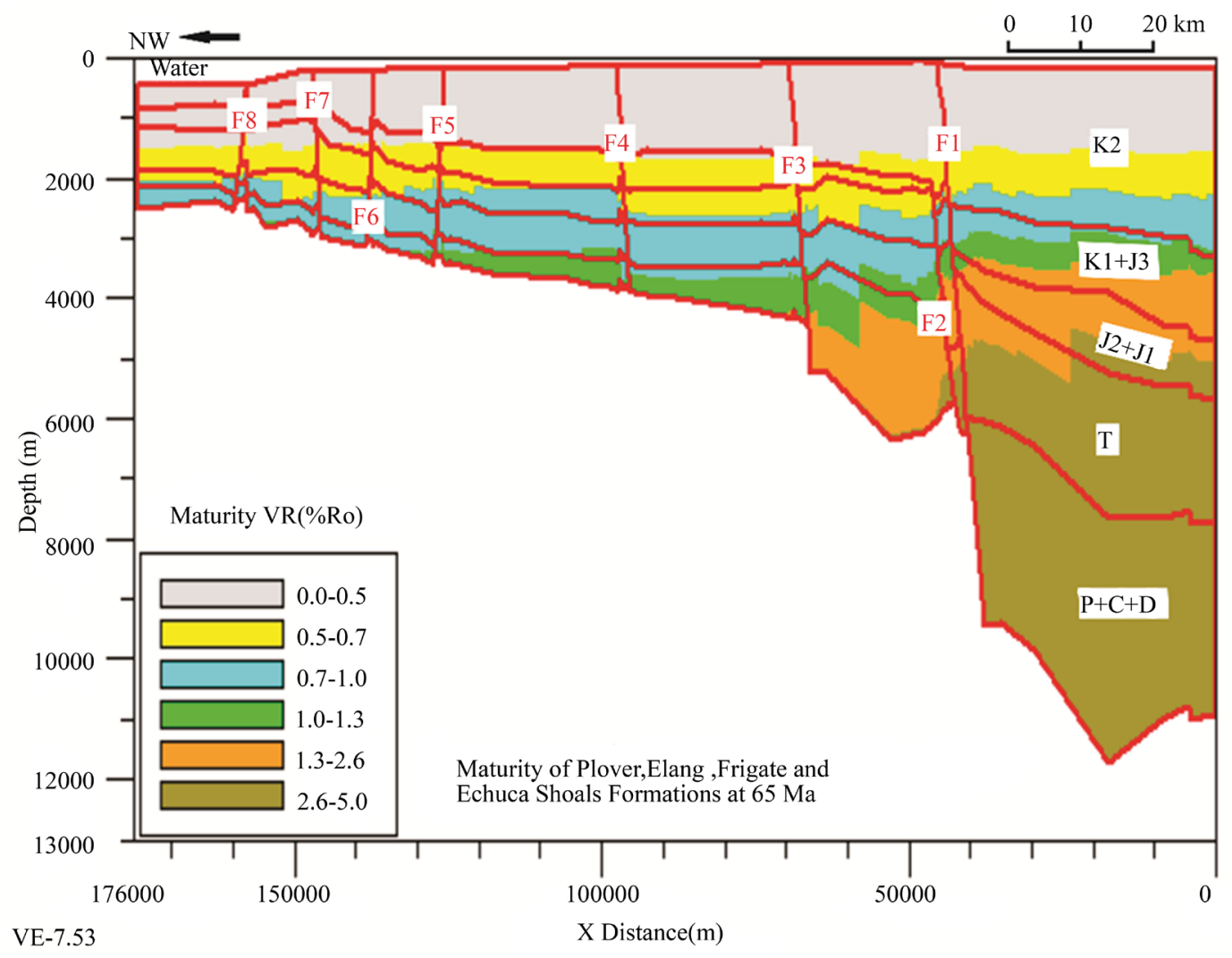

(b) 


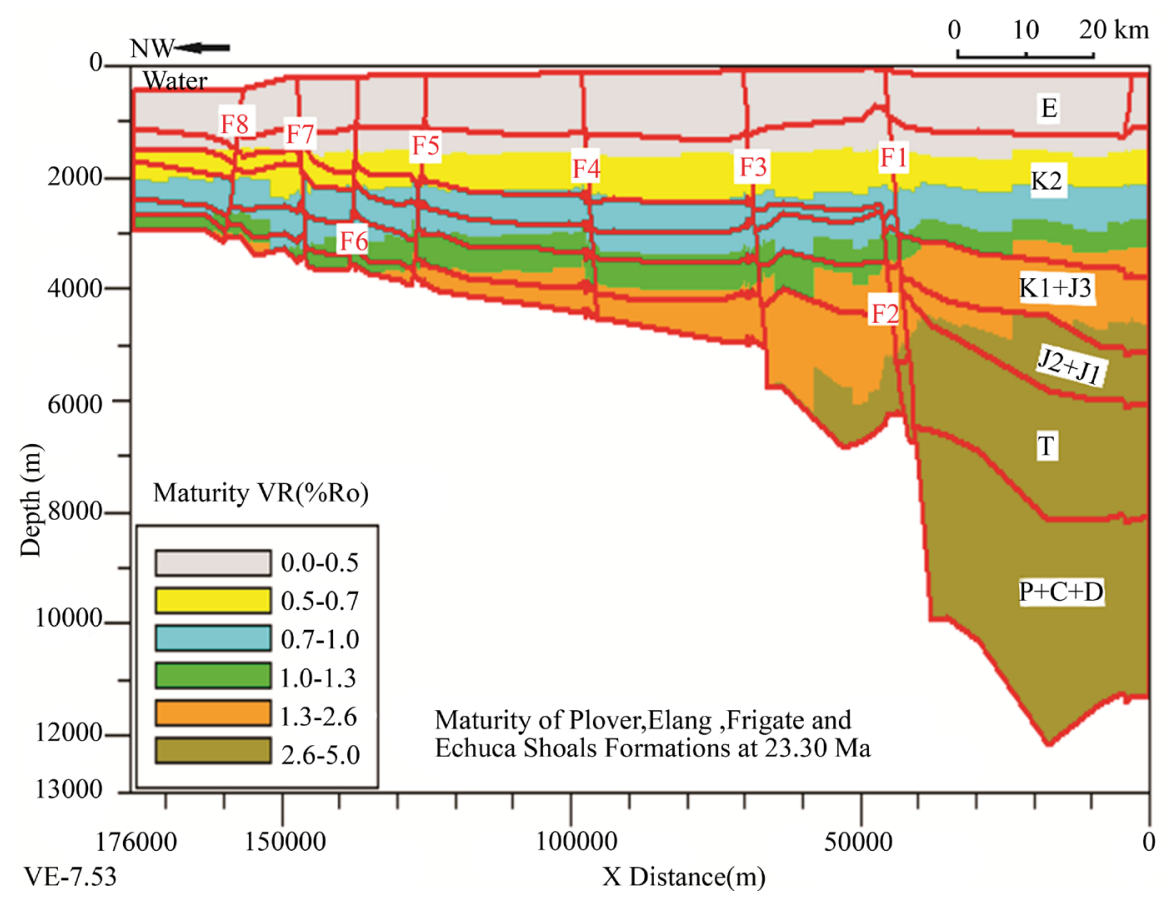

(c)

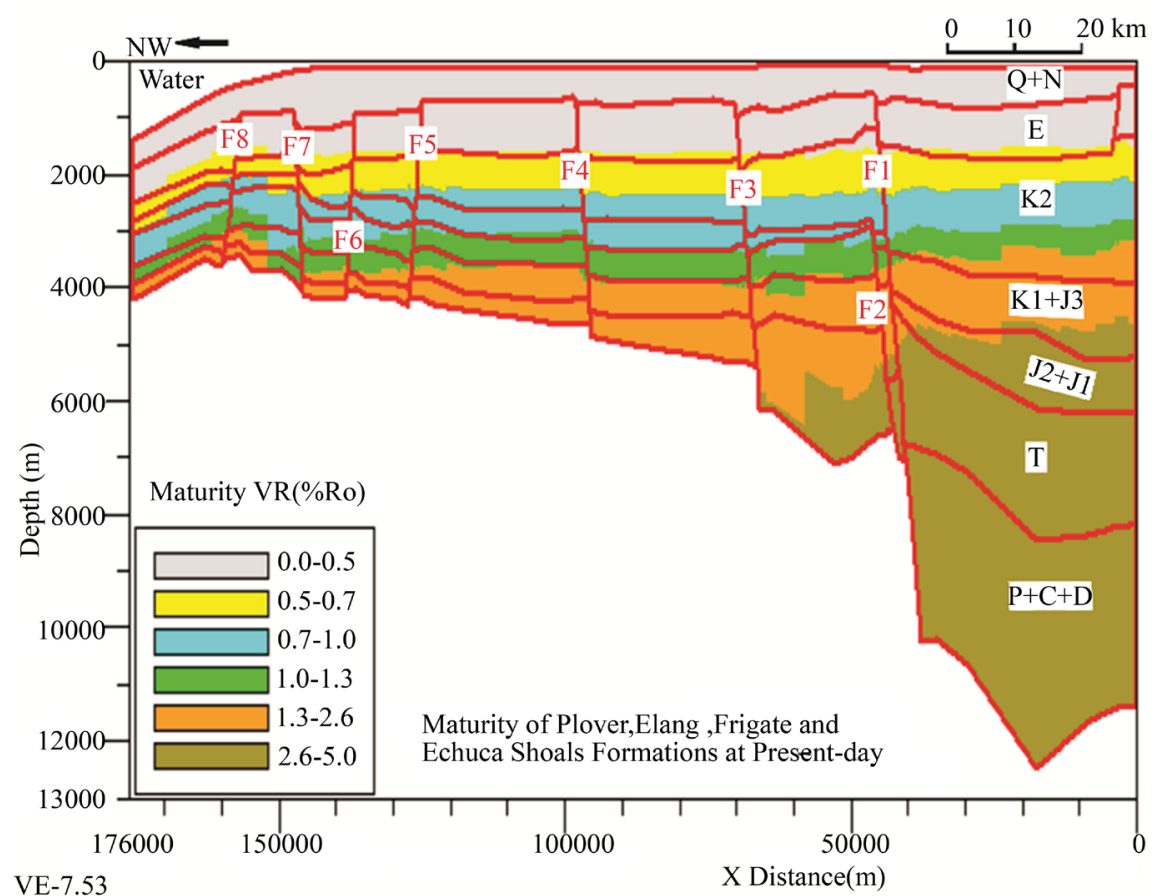

(d)

Figure 6. Schematic diagrams showing the maturity evolution history of the Plover, Elang, Frigate and Echuca Shoals formations source rocks obtained from Seismic Line N11606: (a) Source rock maturation at 95 Ma; (b) Source rock maturation at $65 \mathrm{Ma}$; (c) Source rock maturation at $23.30 \mathrm{Ma}$; (d) Source rock maturation at present-day. The formation names are indicated in black capital alphabets: $\mathrm{Q}+\mathrm{N}$ = Oliver, Barracouta and Alaria formations; $\mathrm{E}=$ Johnson, Hibernia and Cartier formations; $\mathrm{K}_{2}=$ Vee, Turnstone and Puffin formations; $\mathrm{K}_{1}+\mathrm{J}_{3}=$ Elang (Laminaria), Frigate, Echuca Shoals, Darwin and Wangarlu formations; $\mathrm{J}_{2}+\mathrm{J}_{1}=$ Plover Formation; $\mathrm{T}=$ Mount Goodwin Subgroup, Pollard, Cape Londonderry, Challis, Nome, and Malita formations and P + C + D = Fossil Head Formation, and Hyland Bay Subgroup. The faults are indicated in red capital letters: F1 to F8. 
brackish to open marine shales. The two main microscopic-scale rock properties that control fluid storage and flow in a reservoir are porosity and permeability. Porosity versus Depth (Figure 7) and Permeability versus Depth (Figure 8) of the Plover Formation sandstone reservoir for the Loxton Shoals 1, Sunset 1 and Chuditch 1 wells according to a rough field appraisal of porosities in percent and permeabilities in millidarcy of the most common reservoir rocks [37] is given in Table 3. Porosity-permeability relationship (Figure 9) of the Plover Formation sandstone reservoir of the previous three wells [38], and the Seismic Line N11606 (Figure 10) using BasinMod 2-D were used to evaluate the reservoir properties of the Plover Formation sandstone reservoir in the Sahul Platform. In the well Loxton Shoals 1, the Plover Formation layer thickness is $215.50 \mathrm{~m}$ andthe gross gas column thickness is $64 \mathrm{~m}$, which represents $29.70 \%$. And net to gros ratio of $43.28 \%$ represents $27.70 \mathrm{~m}$ net

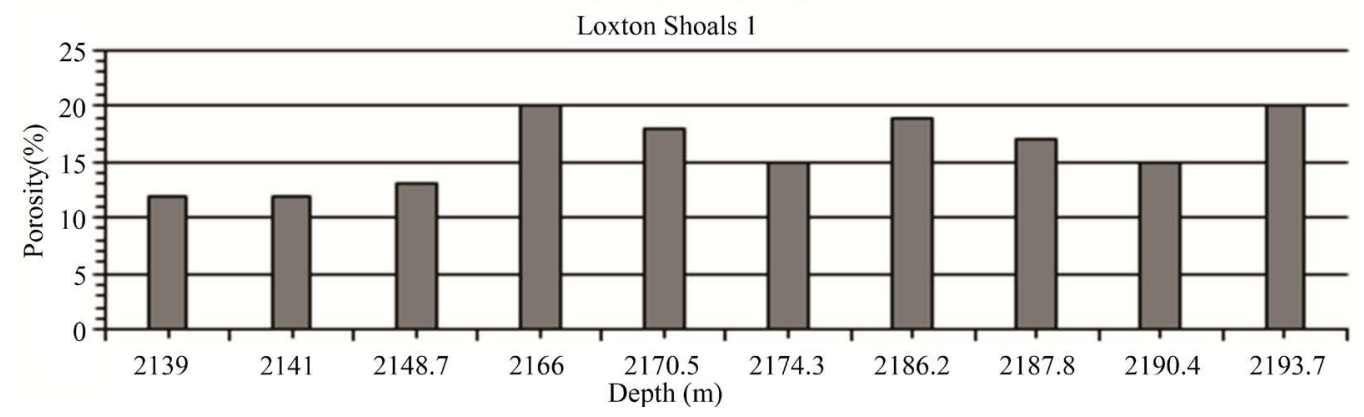

Sunset 1
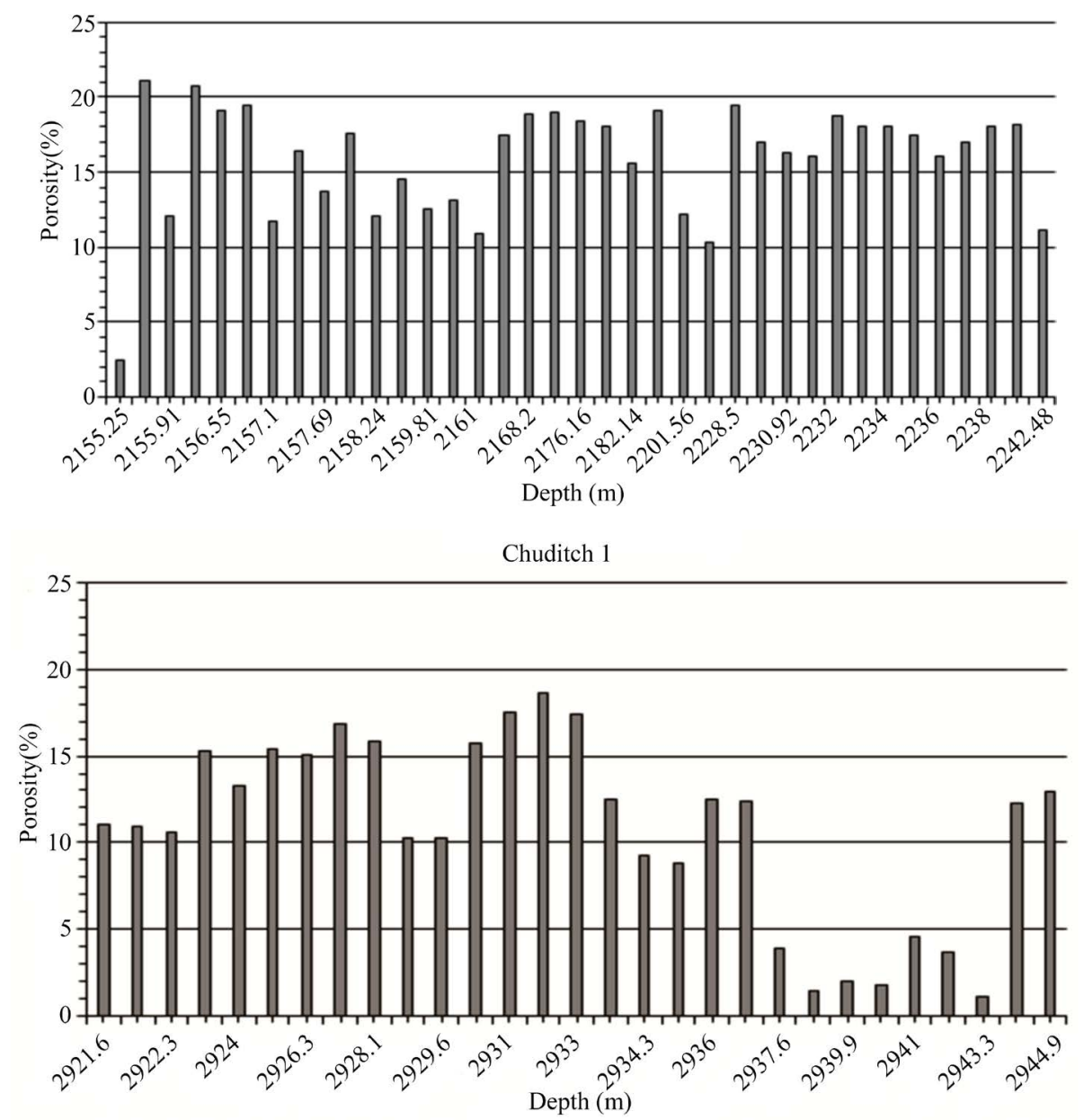

Figure 7. Porosity versus depthof the plover formation sandstone reservoir for the three wells in the sahul platform. 

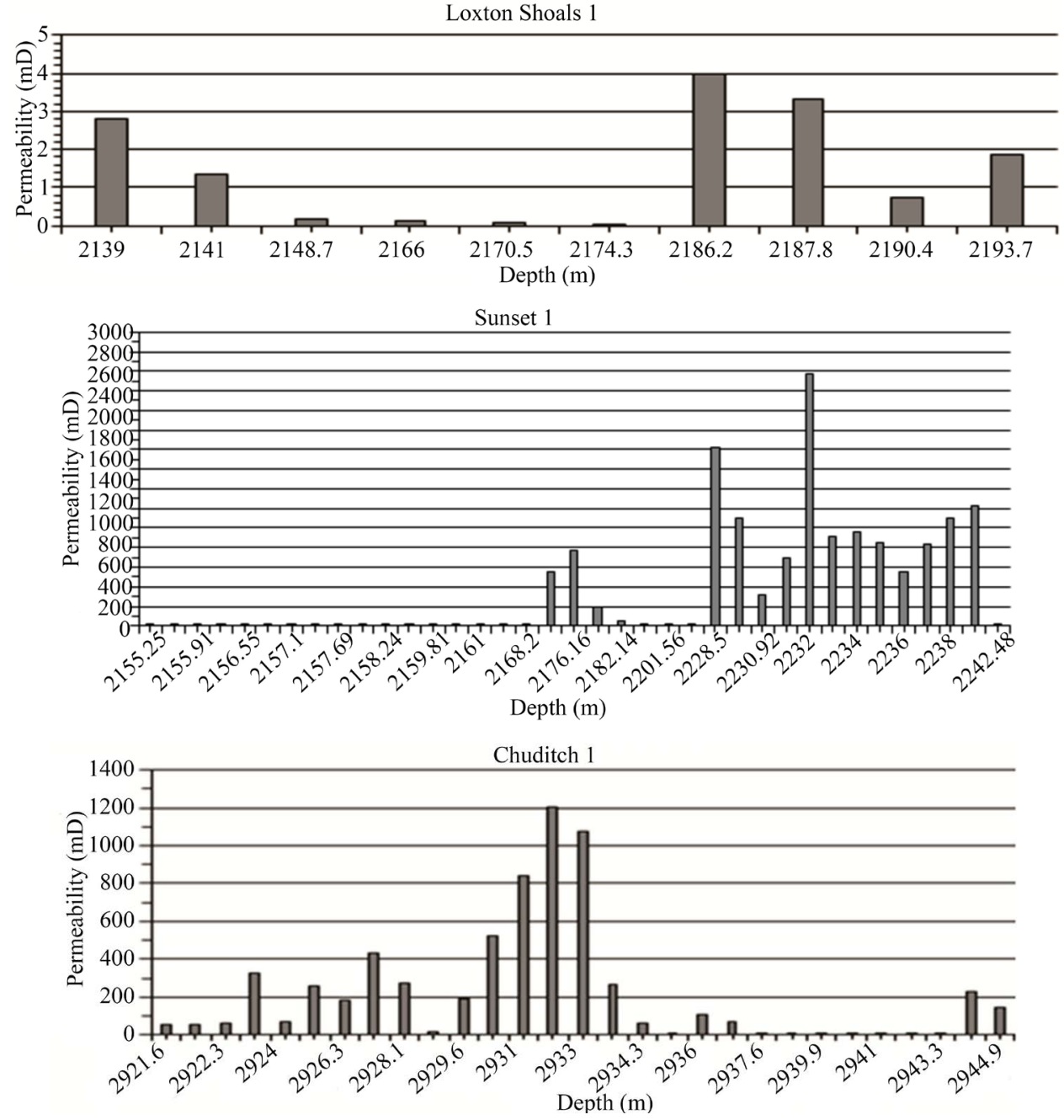

Figure 8. Permeability versus depth of the Plover Formation sandstone reservoir for the three wells in the Sahul Platform.

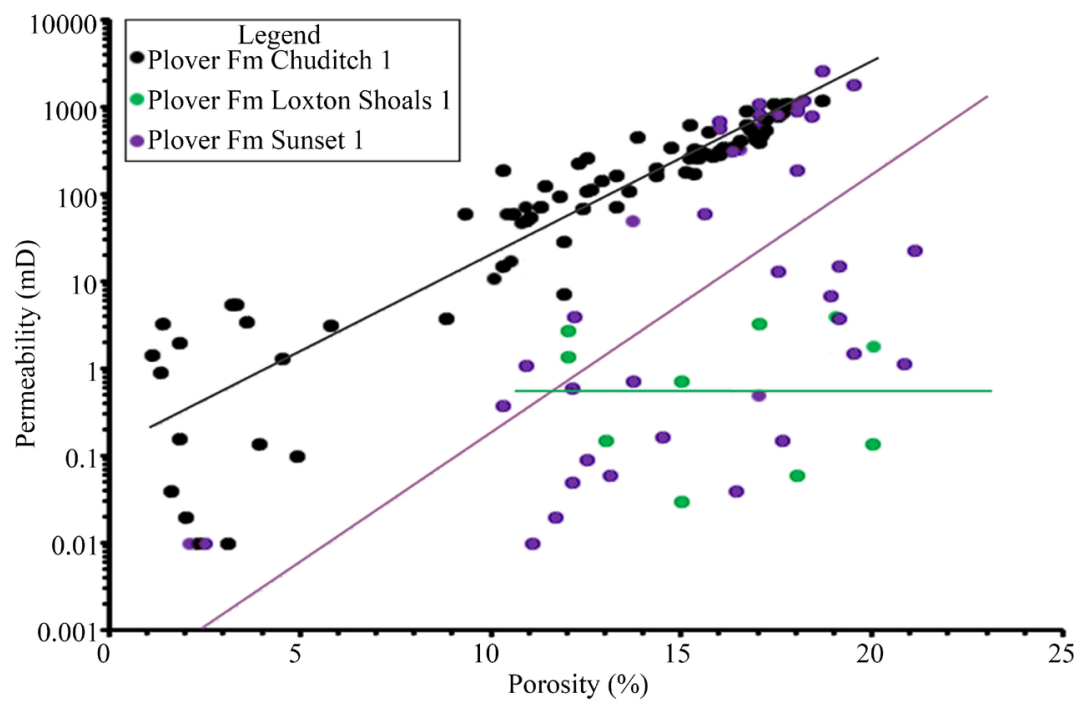

Figure 9. Porosity versus permeability trends for the Plover Formation (Fm) sandstone reservoir of the wells Sunset 1 , Loxton Shoals 1 and Chuditch 1 in the Sahul Platform, $\mathrm{mD}$ is millidarcy. 

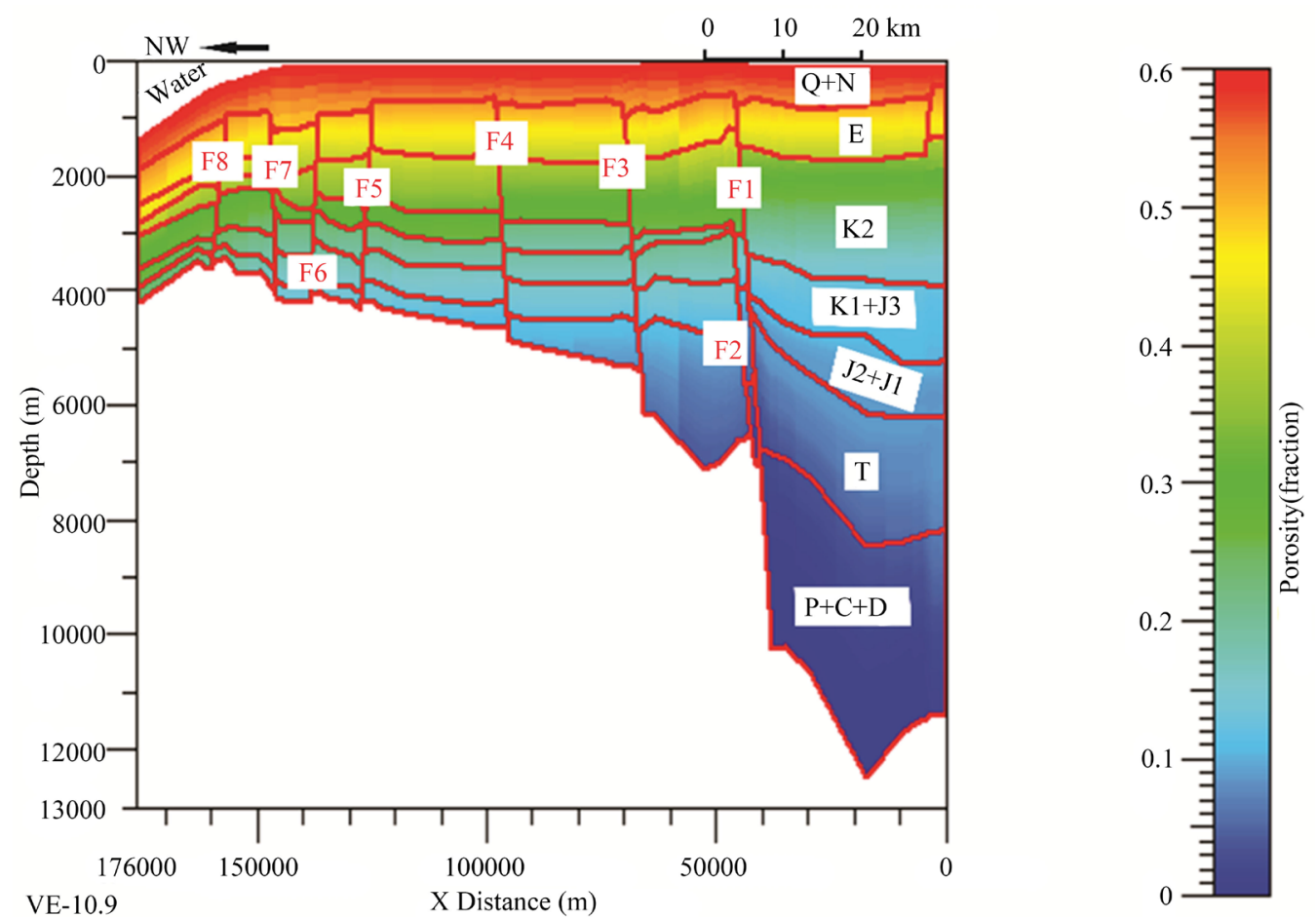

(a)
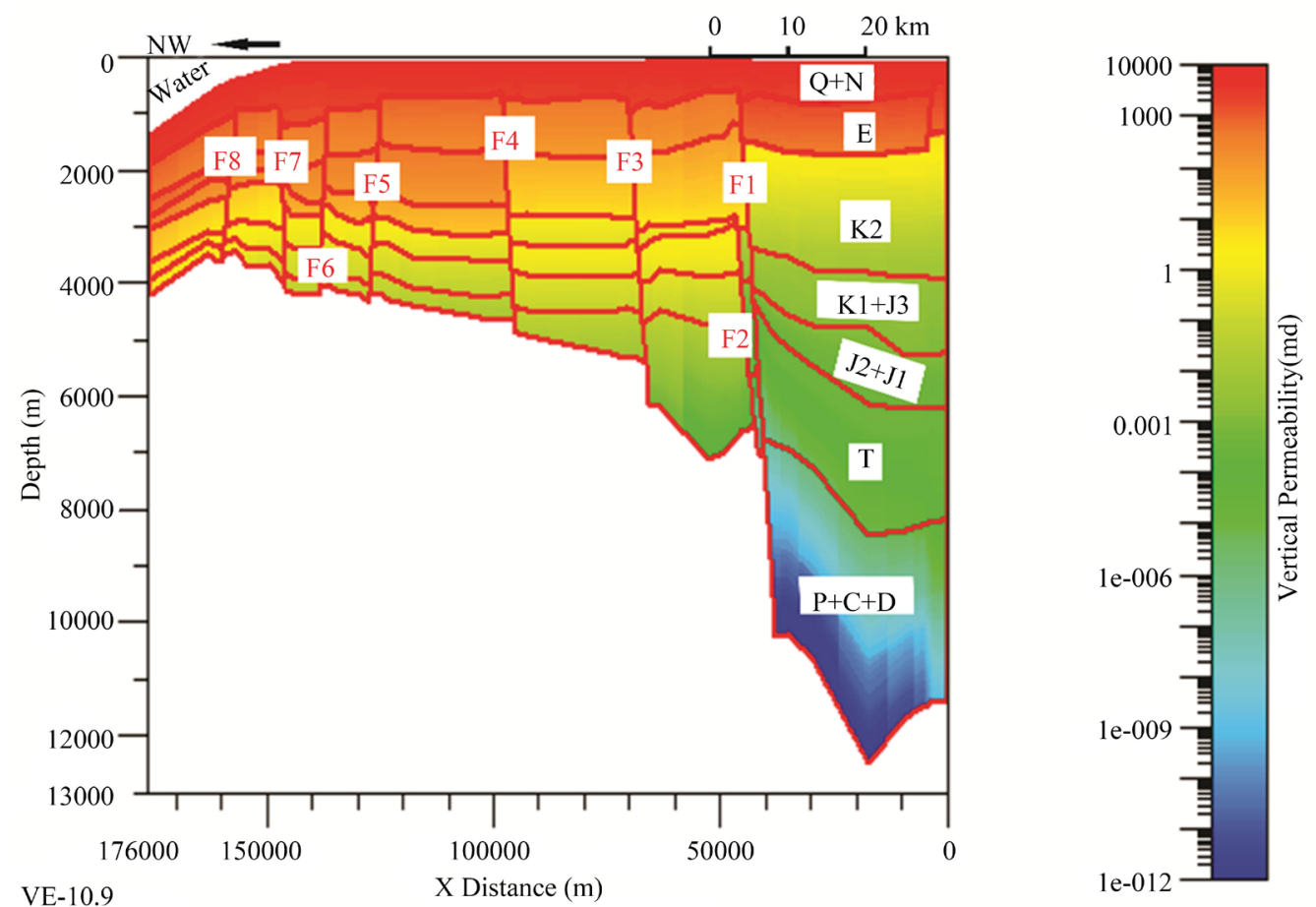

(b)

Figure 10. Two-dimensional (a) Porosity and (b) Permeability versus depth at the present day obtained from the Seismic Line N11606 in the Sahul Platform, the formation names are indicated in black capital alphabets: Q + N = Oliver, Barracouta and Alaria formations; $\mathrm{E}=$ Johnson, Hibernia and Cartier formations; $\mathrm{K}_{2}=$ Vee, Turnstone and Puffin formations; $\mathrm{K}_{1}+\mathrm{J}_{3}=$ Elang (Laminaria), Flamingo, Echuca Shoals, Darwin and Wangarlu formations; $\mathrm{J}_{2}+\mathrm{J}_{1}=$ Plover Formation; $\mathrm{T}=\mathrm{Mount}$ Goodwin Subgroup, Pollard, Cape Londonderry, Challis, Nome, and Malita formations and P + C + D = Fossil Head Formation, and Hyland Bay Subgroup. The faults are indicated in red capital letters: F1 to F8. 
Table 3. Appraisal of porosities and permeabilities of reservoir rocks (Levorsen, 1967).

\begin{tabular}{cccc}
\hline $\begin{array}{c}\text { Porosity } \\
(\%)\end{array}$ & A rough appraisal reservoir rock & $\begin{array}{c}\text { Permeability } \\
(\mathrm{mD})\end{array}$ & A rough appraisal reservoir rock \\
\hline $0-5$ & Negligible & $<0.1$ & Gompacted \\
$5-10$ & Poor & $10-0.1$ & Low permeability \\
$10-15$ & Fair & & Conventional \\
$15-20$ & Good & $100-10$ & \\
$20-25$ & Very good & & \\
$>25$ & Excellent & & \\
\hline
\end{tabular}

Where \% is percent and $\mathrm{mD}$ is millidarcy.

reservoir. The top reservoir was intersected at $2162 \mathrm{mRT}$ and a free water level at $2226 \mathrm{mRT}$. Ten (10) measured porosity and permeability values readings were recorded ranging from $12 \%$ to $20 \%$ with an average of $16.10 \%$ and from 0.03 to $3.99 \mathrm{mD}$ with an average of $1.44 \mathrm{mD}$. These values indicated that the Plover Formation sandstone reservoir was fair-to-good porosity and negligible-to-low permeability for gas bed. In the well Sunset 1 , the gross gas column thickness is $96 \mathrm{~m}$ representing $36.23 \%$ of the $265 \mathrm{~m}$ Plover Formation sediment thickness. And net to gros ratio of $36.15 \%$ represents $34.70 \mathrm{~m}$ net reservoir. The top reservoir was traversed at $2155 \mathrm{mRT}$ and gas water contact at $2251 \mathrm{mRT}$. Thirty seven (37) porosity and permeability values were recorded, which varied from $2.5 \%$ to $21.10 \%$ with an average of $15.89 \%$ and 0.01 to $2580 \mathrm{mD}$ with an average of $394.50 \mathrm{mD}$. This showed very poor-to-very good porosity and negligible-to-very good permeability for gas bed. In the well Chuditch 1, the Plover Formation sediment thickness is $116 \mathrm{~m}$, andthe gross gas column thickness is $25.13 \mathrm{~m}$ represents $21.66 \%$. And net to gros ratio of $78 \%$ represents $19.60 \mathrm{~m}$ net reservoir. The top reservoir was intersected at $2920 \mathrm{mRT}$ and a free water level at $2945.13 \mathrm{mRT}$. Seventy three (73) measured porosity and permeability values were recorded varying from $1.10 \%$ to $18.70 \%$ with an average of $12 \%$ and $0.01 \%$ to $1204 \mathrm{mD}$ with an average of $287.32 \mathrm{mD}$. These values showed that the Plover Formation sandstone reservoir was negligible-to-good porosity and very low-to-very good permeability for gas bed. In Figure 7 and Figure 8, some depths have high or very low porosity or permeability values. These values indicated that the porosity of all samples is highly variable and depends upon a combination of original lithology, texture and diagenesis involving compaction. Original lithology exerts the major control as indicated by a significantly reduced porosity in matrix-rich samples. Moreover, permeability is likely very poor where porosity is largely occluded by matrix and the worst reservoir intervals coincide with siltstone and silty claystone lithologies. The textural control on the reservoir quality is clear and is indicated by the strong relationship between grain size and permeability, as grain size increases, the permeability increases, and conversely. Compaction and cementation processes have contributed to the porosity loss, but where local dissolution of framework grain composition occurred the reservoir potential has been locally enhanced. Porosity is interconnected, implying good permeability.

The porosity-permeability relationship for the well Loxton Shoals 1, fluvio-deltaic to marginal marine depositional environments, displayed fair-to-good porosity, and low permeability (consistently less than $10 \mathrm{mD}$ ). The porosities were poorly interconnected; this was due to the presence of detrital clay matrix. Generally, the reservoir quality was poor and potential was low. However, the lower limit for direct contribution to gas flow was estimated to lie between 0.1 and $10 \mathrm{mD}$, thus small volumes of gas may be recovered by the well Loxton Shoals 1 . One successful Modular Dynamics Test (MDT) and Repeat Formation Test (RFT) were conducted. MDT (2939 $\mathrm{mRT}$ ) recovered $47.50 \mathrm{scf}$ (standard cubic feet) of gas and 0.0016 barrel of condensate. RFT (2139.1 mRT) recovered 47.89 scf of gas. In the well Sunset 1, marginal marine to fluvio-deltaic depositional environments, showed an increase in porosity is paralleled by a permeability. Reservoir quality of Sunset 1 sandstones varied from poor-to-very good. The lower part of reservoir from 2175 to $2241 \mathrm{mRT}$ had the high potential. The porosities were interconnected due to the many pores that had been enlarged by dissolution and relatively little quartz cement was present in the pores or pore throats, implying good permeability, consequently good potential reservoir; however, the upper section above $2175 \mathrm{mRT}$ had the low potential due to the presence of detrital depositional matrix. The porosities were low interconnected giving a low permeabilities and reservoir quality. In the 
well Chuditch 1, deltaic to shallow marine depositional environments, displayed an increase in porosity is paralleled by a permeability. Reservoir potential of Chuditch 1 sandstones ranged from very poor-to-very good. The upper part from $2934 \mathrm{mRT}$ to the top reservoir had a good potential with porosities ranged from $10.30 \%$ to 18.70\% and permeabilities from 14.90 to $1204 \mathrm{mD}$, and the lower part of reservoir, below $2934 \mathrm{mRT}$ was poorto-fair potential, the porosities were poor-to-fair interconnected indicating reservoir potential was low-tomoderate. One MDT was conducted at $2934 \mathrm{mRT}$, which recovered $243.67 \mathrm{scf}$ of gas. It was better to conduct the Wireline Formation Test (WFT) in the upper part of reservoir of the well Chuditch 1.

On the other hand, the interpretation of the Plover Formation reservoir properties was estimated using the Seismic Line N11606. In the north margin of the Sahul Platform, the porosity and permeability values were $18 \%$ to $22 \%$ and 5 to $200 \mathrm{mD}$, respectively. This indicated good-to-very good porosity and low-to-good permeability for gas bed, whereas in the south margin the porosity and permeability values ranged from 10\% to 15\% (Figure 10(a)) and 10 to $100 \mathrm{mD}$ (Figure 10(b)), respectively. This showed fair-to-good porosity and good permeability for gas bed. The porosity and permeability values were decreasing with the burial depth showing complete sediment compaction and equilibrium during the sedimentation of the study area. The model results have shown that the porosity and permeability values of 2D model were almost comparable with $1 \mathrm{D}$ value reflecting the accuracy of both 1D and 2D models.

\subsection{Hydrocarbon Generation}

The hydrocarbon generation from the source rock has been deduced from its maturation history using correlations between calculated maturity and measured mean vitrinite reflectance and heat flow regime. The amount of gas generated from the source rock in the individual well has been estimated assuming that it is derived from the cracking of oil remaining in the source rock after the oil generation ceased. In the well Loxton Shoals 1 , the threshold of hydrocarbon generation of the Plover Formation source rock was occurred during Late Cretaceous at the depth of $676 \mathrm{~m}$ and temperature of $80^{\circ} \mathrm{C}$, the mid-mature oil at Early Miocene at the depth of about $1571.82 \mathrm{~m}$ and temperature of $118^{\circ} \mathrm{C}$, and late mature oil window during the Early Pliocene at the depth of 2096 $\mathrm{m}$ and at the temperature of $143^{\circ} \mathrm{C}$, it is currently at the late mature oil window (Figure 11(a)). The amount of generated oil was $14.28 \mathrm{mg} / \mathrm{g}$ TOC (Figure 12(a)) with generation rate of $0.95 \mathrm{mg} / \mathrm{g}$ TOC $\times$ Ma (Figure 12(b)) and gas was $31.38 \mathrm{mg} / \mathrm{g}$ TOC (Figure 11(a)) with generation rate of $2.10 \mathrm{mg} / \mathrm{g}$ TOC $\times$ Ma (Figure 12(b)) and they reached the peak generation during the Early Pliocene. In the well Sunset 1, the Plover Formation source rock entered early mature oil window during Late Paleocene at the depth of $1050 \mathrm{~m}$ and temperature of $80^{\circ} \mathrm{C}$, and the mid-mature oil window at Late Miocene at the depth of $1976 \mathrm{~m}$ and temperature of $111^{\circ} \mathrm{C}$, and at the present time it is in mid-mature oil window (Figure 11(b)). The amount of generated oil was $7.27 \mathrm{mg} / \mathrm{g}$ TOC (Figure 13(a)) with generation rate of $0.64 \mathrm{mg} / \mathrm{g}$ TOC $\times$ Ma (Figure 13(b)) and the amount of generated gas was $16.17 \mathrm{mg} / \mathrm{g}$ TOC (Figure 12(a)) with generation rate of $1.41 \mathrm{mg} / \mathrm{g}$ TOC $\times$ Ma (Figure 13(b)) and they reached the peak generation during Quaternary. The start of oil window of the Plover, Flamingo (Upper Frigate) and Echuca Shoals formations source rocks in the well Chuditch 1began at the Late Cretaceous at the depth of about $1130 \mathrm{~m}, 1098 \mathrm{~m}$, and $1090 \mathrm{~m}$, respectively, and temperature of $88^{\circ} \mathrm{C}$, and the mid-mature oil window during the Late Paleocene for Plover Formation and Early Eocene for Flamingo and Echuca Shoals formations at the depth of $2030 \mathrm{~m}, 1976 \mathrm{~m}$, and $1968 \mathrm{~m}$, and at the temperature of $114^{\circ} \mathrm{C}, 113^{\circ} \mathrm{C}$, and $112.5^{\circ} \mathrm{C}$, respectively (Figure 11(c)). The amounts of oil generated from these three formations were 17.19, 16.98, and $13.27 \mathrm{mg} / \mathrm{g}$ TOC (Figure 14(a)) with generation rate of $0.45,0.54$, and $0.42 \mathrm{mg} / \mathrm{Gtoc} \times$ Ma (Figure $14(\mathrm{~b})$ ), and gas were 37.95, 37.53, and $29.32 \mathrm{mg} / \mathrm{g}$ TOC (Figure 14(a)) with generation rate of 1.01, 1.20, and $0.94 \mathrm{mg} / \mathrm{g}$ TOC $\times$ Ma (Figure 14(b)), respectively, and they reached the peak generation at the present-day. The beginning of oil window of the Petrel (Frigate) and Echuca Shoals formations source rocks in the well Heron 1 began in Early and Middle Cretaceous at the depth of $1151 \mathrm{~m}$ and $1120 \mathrm{~m}$ corresponding temperature of $85^{\circ} \mathrm{C}$ and $88^{\circ} \mathrm{C}$, the mid-mature oil at Middle Cretaceous and Late Cretaceous at the depth of about $1900 \mathrm{~m}$ and $1850 \mathrm{~m}$, and at temperature of $118^{\circ} \mathrm{C}$ and $119^{\circ} \mathrm{C}$, the late mature oil window during the Late Cretaceous and Early Paleogene at the depth of about $2650 \mathrm{~m}$ and $2630 \mathrm{~m}$, and at temperature of $148^{\circ} \mathrm{C}$ and $139^{\circ} \mathrm{C}$, and the wet gas window in the Late Cretaceous and Early Neogene at the depth of about $3063 \mathrm{~m}$ and $3328 \mathrm{~m}$, and at temperature of 159 and $154^{\circ} \mathrm{C}$, respectively (Figure 11(d)). The amount of generated oil from these two formations were 15.39 and $11.89 \mathrm{mg} / \mathrm{g}$ TOC (Figure 15(a)) with generation rate of 0.83 and $0.49 \mathrm{mg} / \mathrm{g}$ TOC $\times$ Ma (Figure 15(b)), and gas were 37 and $27.25 \mathrm{mg} / \mathrm{g}$ TOC (Figure 15(a)) with generation rate of 1.85 and $1.09 \mathrm{mg} / \mathrm{g}$ TOC × Ma (Figure 15(b)), respectively, and they reached the peak generation at Late Cretaceous. 

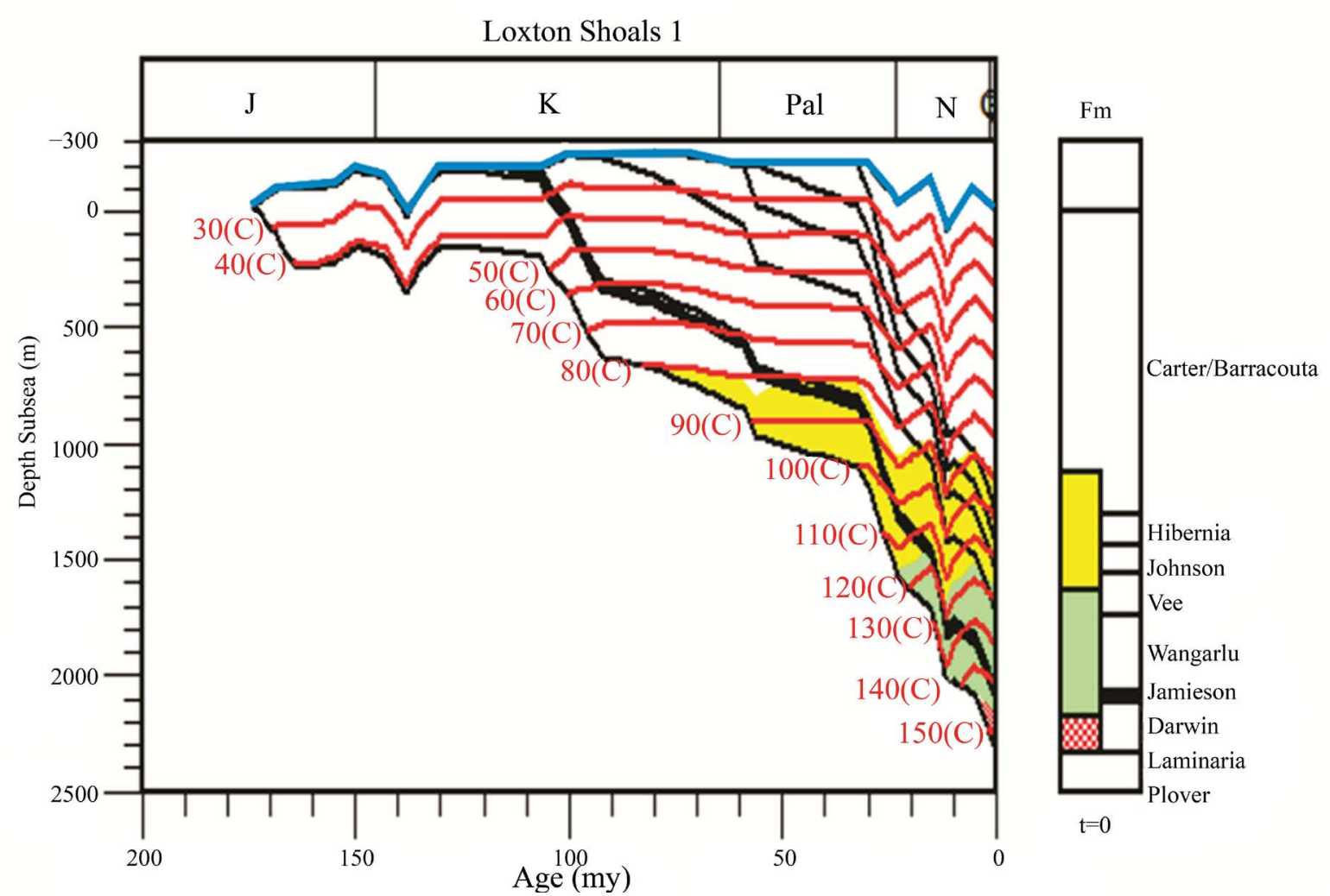

(a)
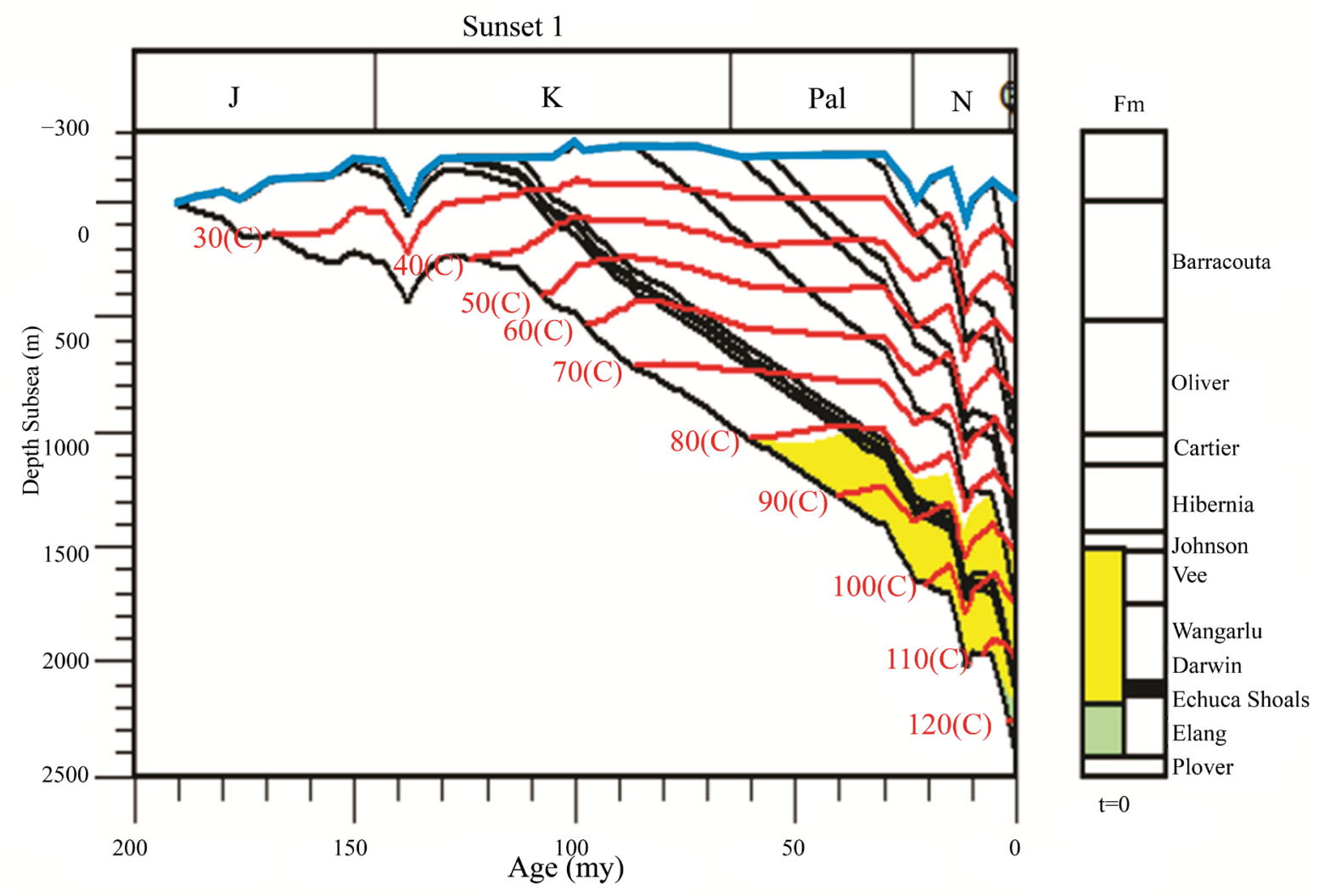

(b) 

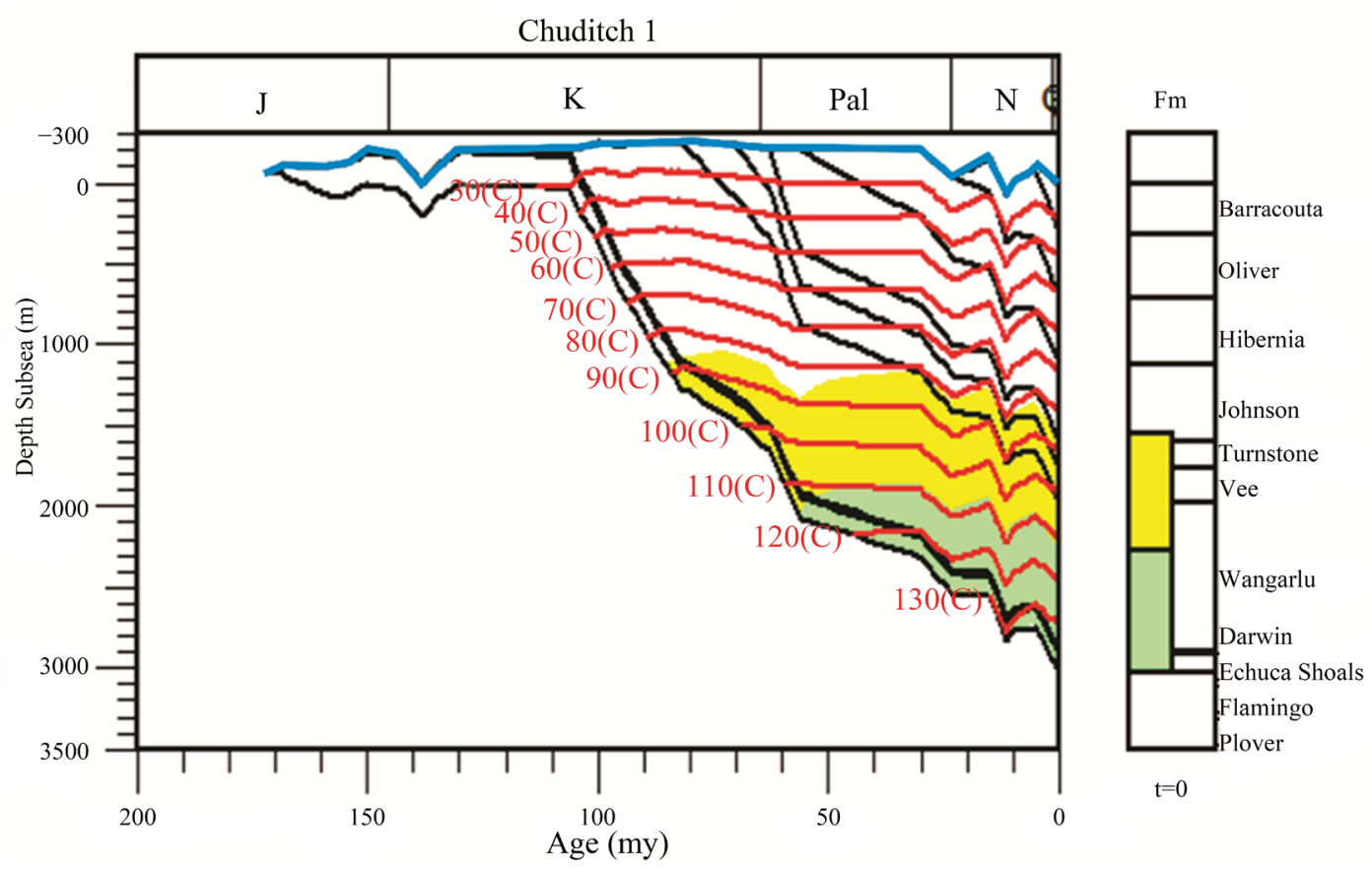

(c)
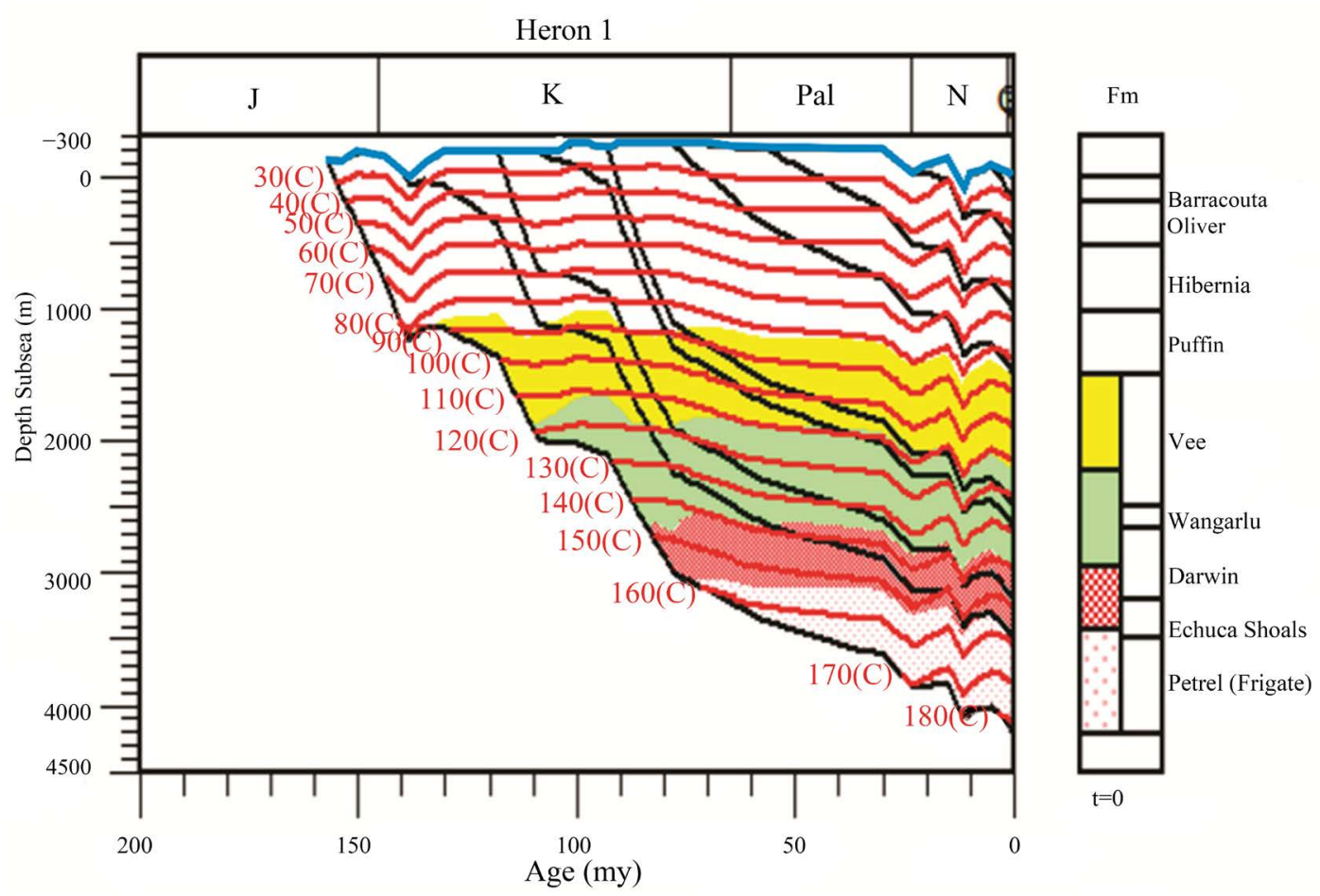

(d)

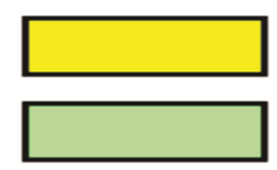

Early Mature (oil) 0.5 to 0.7 (\%Ro)

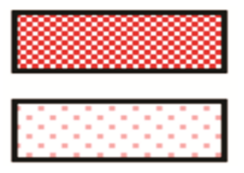

Late Mature (oil)

1 to 1.3 (\%Ro)

Mid Mature (oil)

0.7 to 1 (\%Ro)

Main Gas Generation

1.3 to 2.6 (\%Ro) Sea level

Figure 11. Modelled burial history of the wells Loxton Shoals 1, Sunset 1, Chuditch 1in the Sahul Platform and Heron 1 in the Malita Graben. 


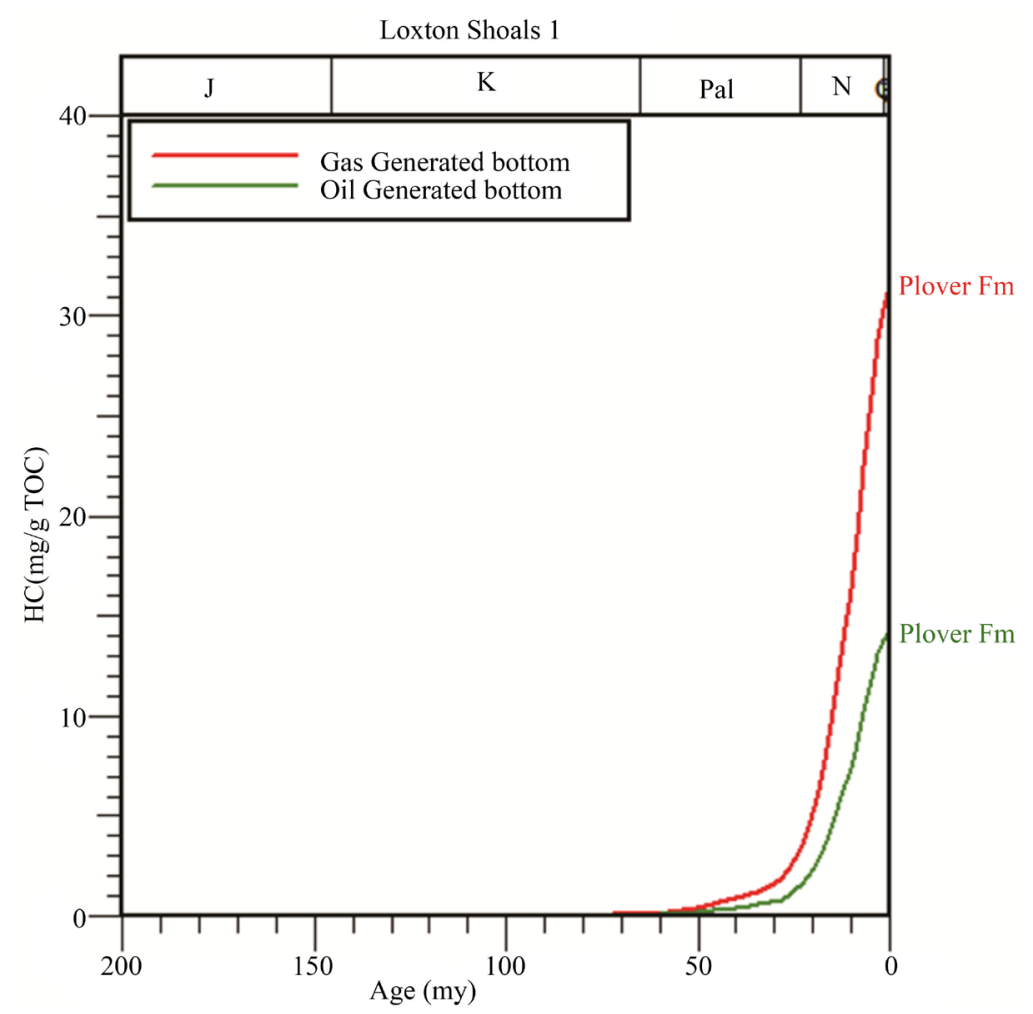

(a)

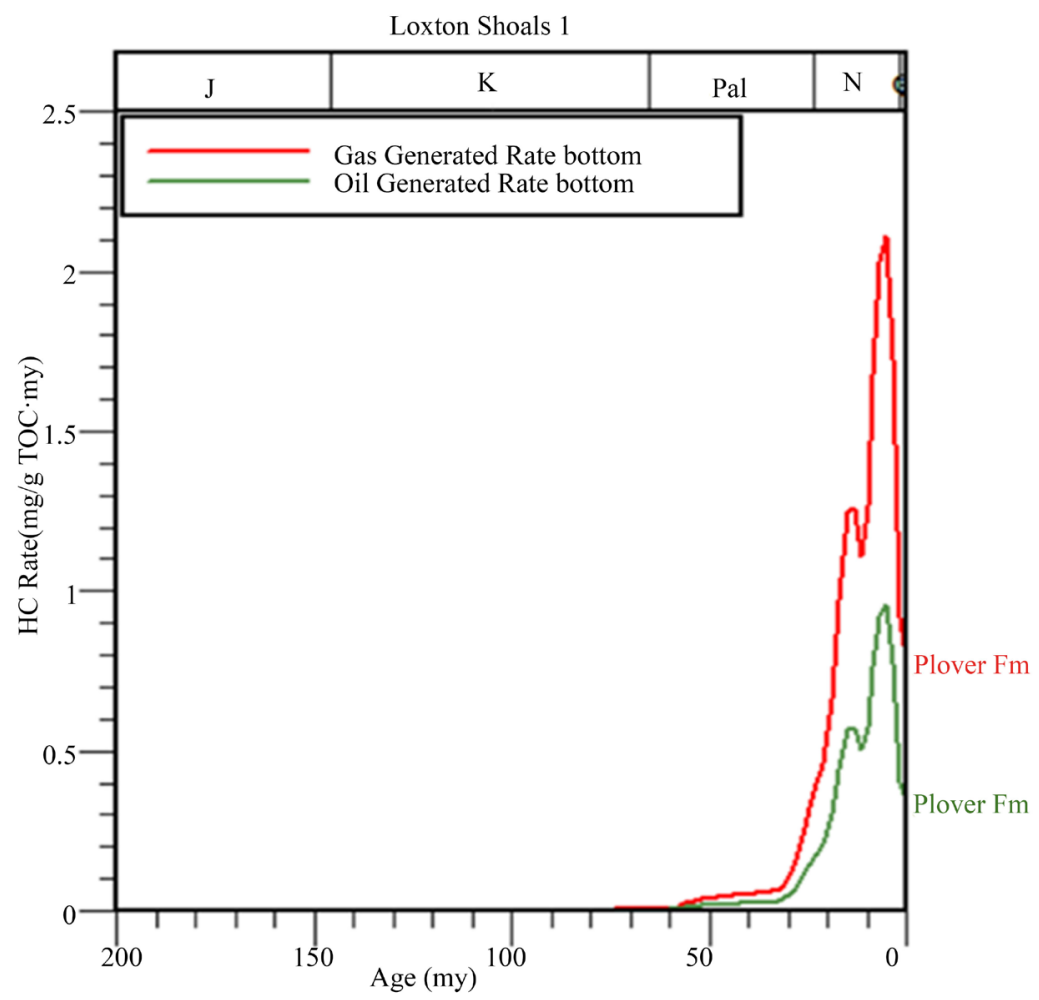

(b)

Figure 12. Modeling results of hydrocarbon generation history in the well Loxton Shoals 1. (a) Amount of hydrocarbon generation; (b) Rate of hydrocarbon showing the peak generation at Early Pliocene. 


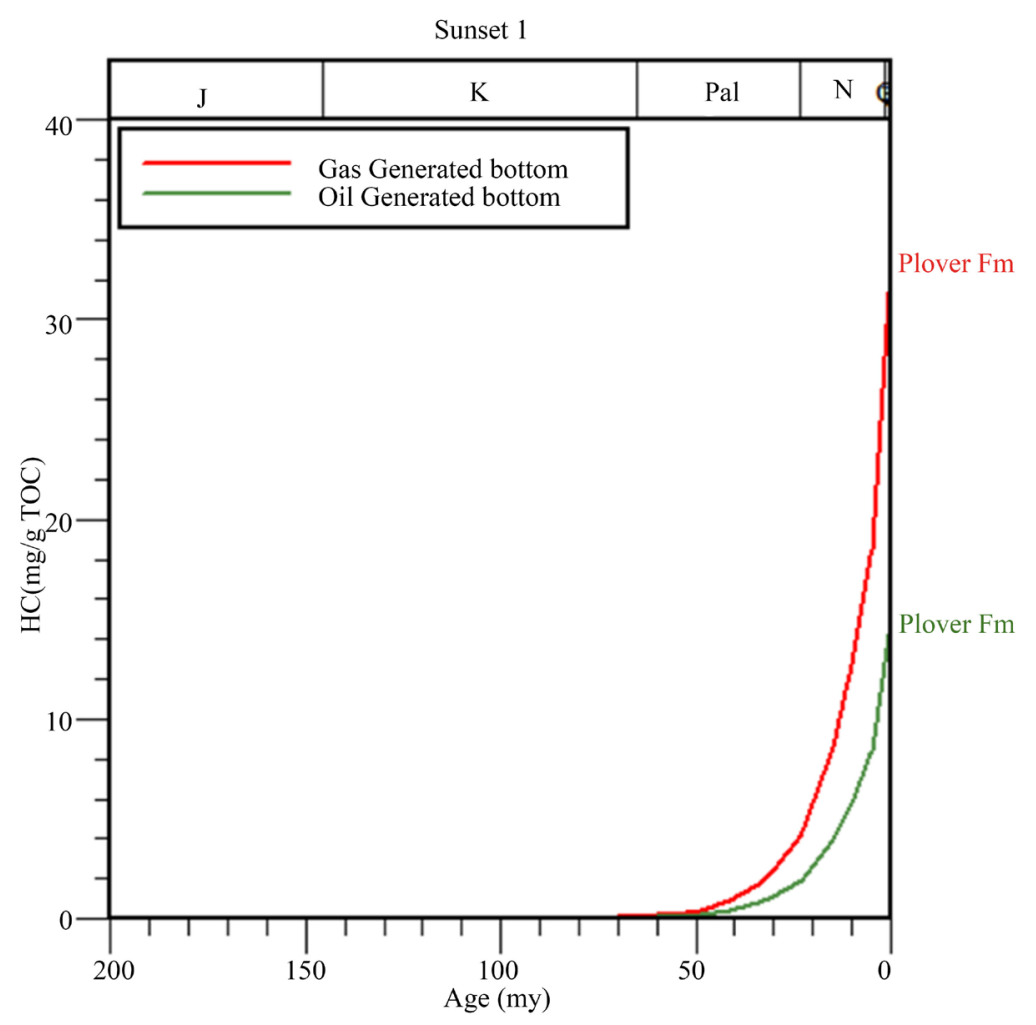

(a)

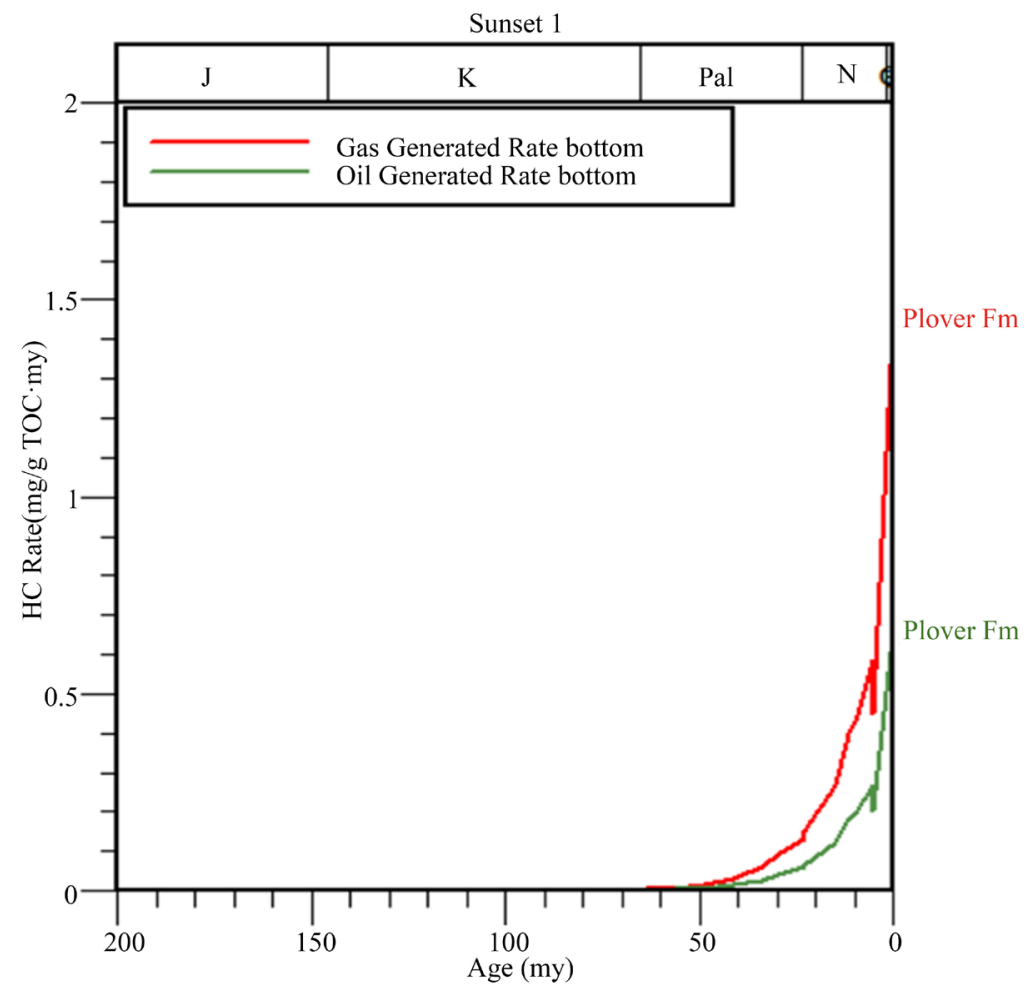

(b)

Figure 13. Modeling results of hydrocarbon generation history in the well Sunset 1. (a) Amount of hydrocarbon generation; (b) Rate of hydrocarbon showing the peak generation at Quaternary. 


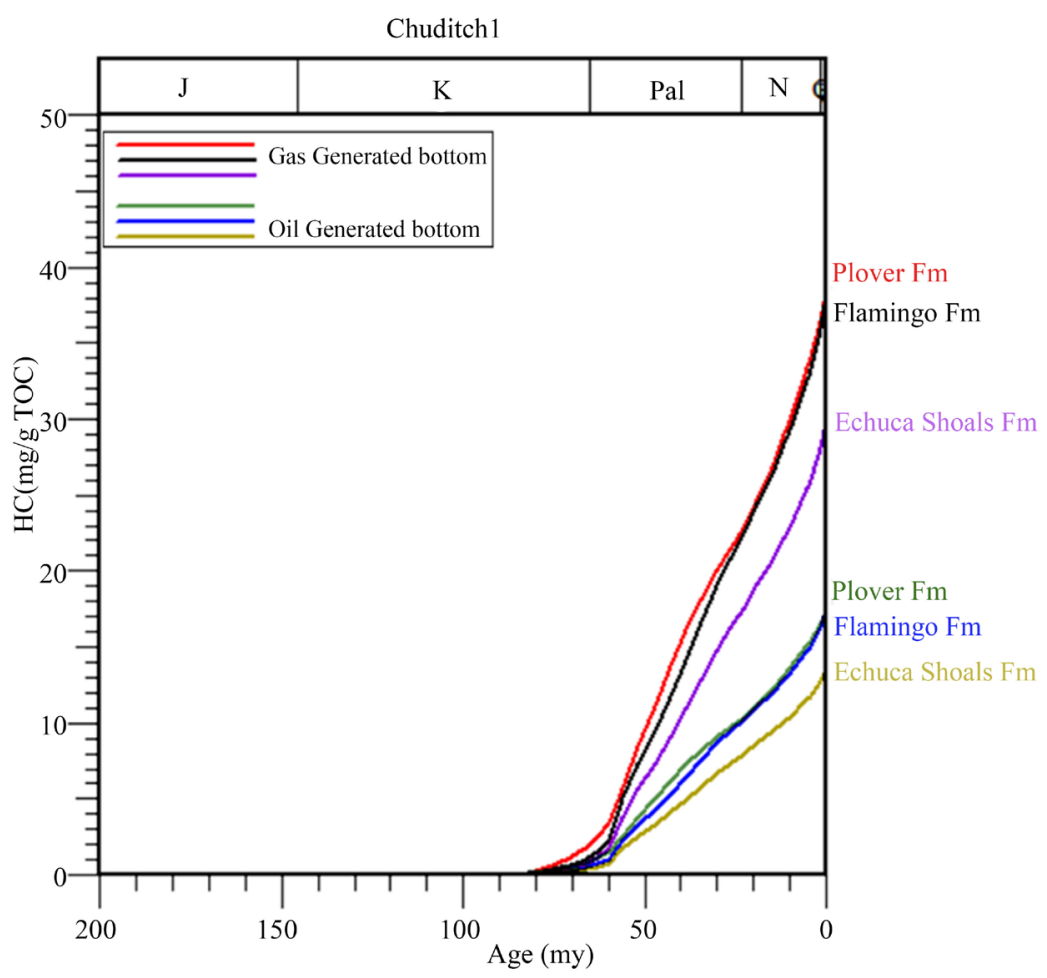

(a)

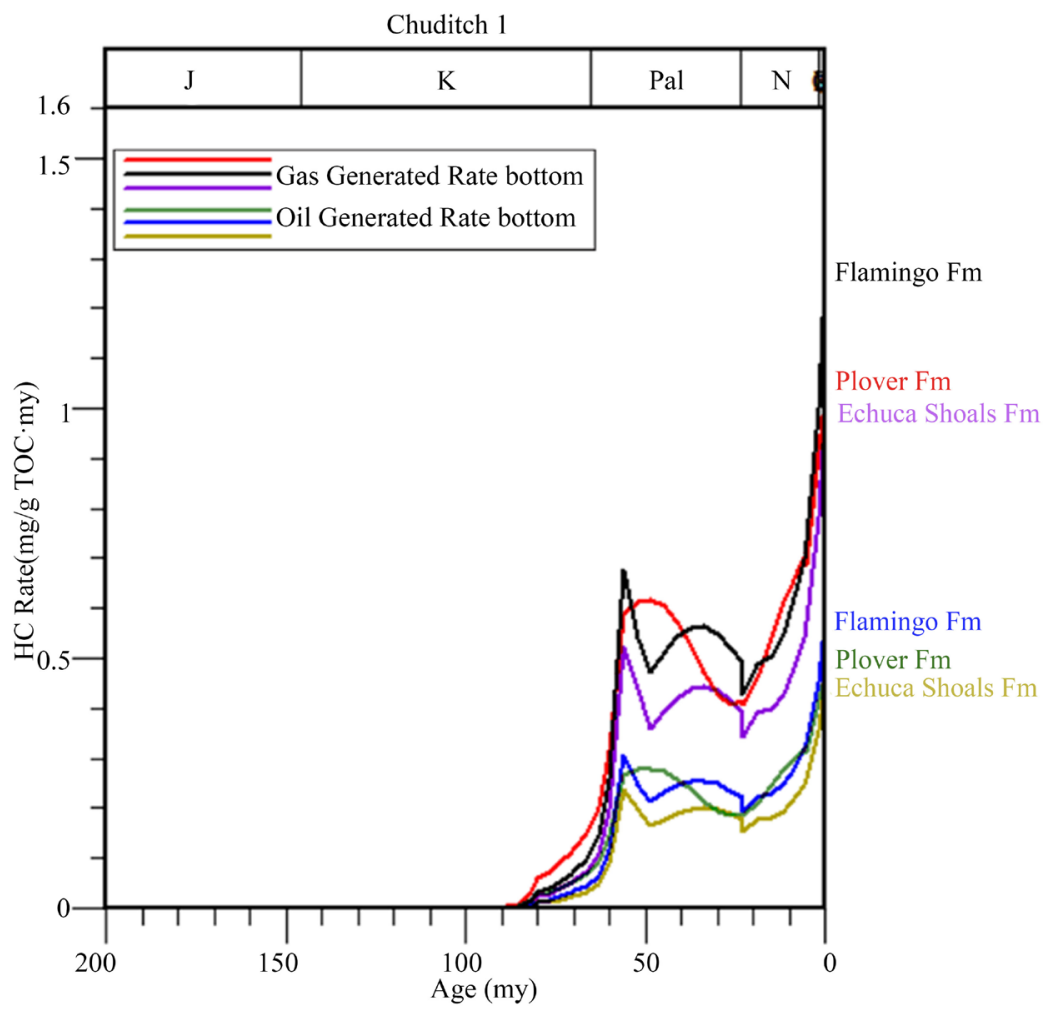

(b)

Figure 14. Modeling results of hydrocarbon generation history inthe well Chuditch 1. (a) Amount of hydrocarbon generation; (b) Rate of hydrocarbon showing the peak generation at Quaternary for the Plover, Flamingo and Echuca Shoals formations. 


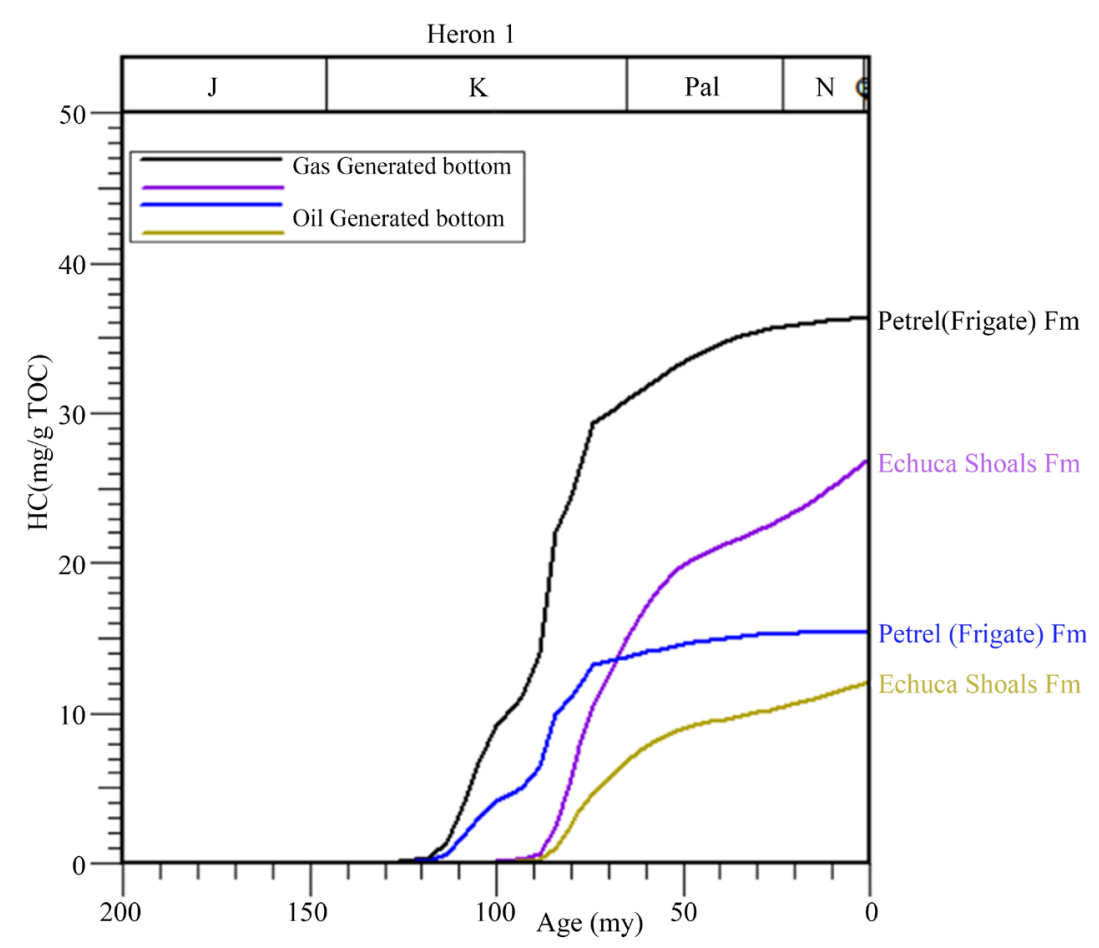

(a)

Heron 1

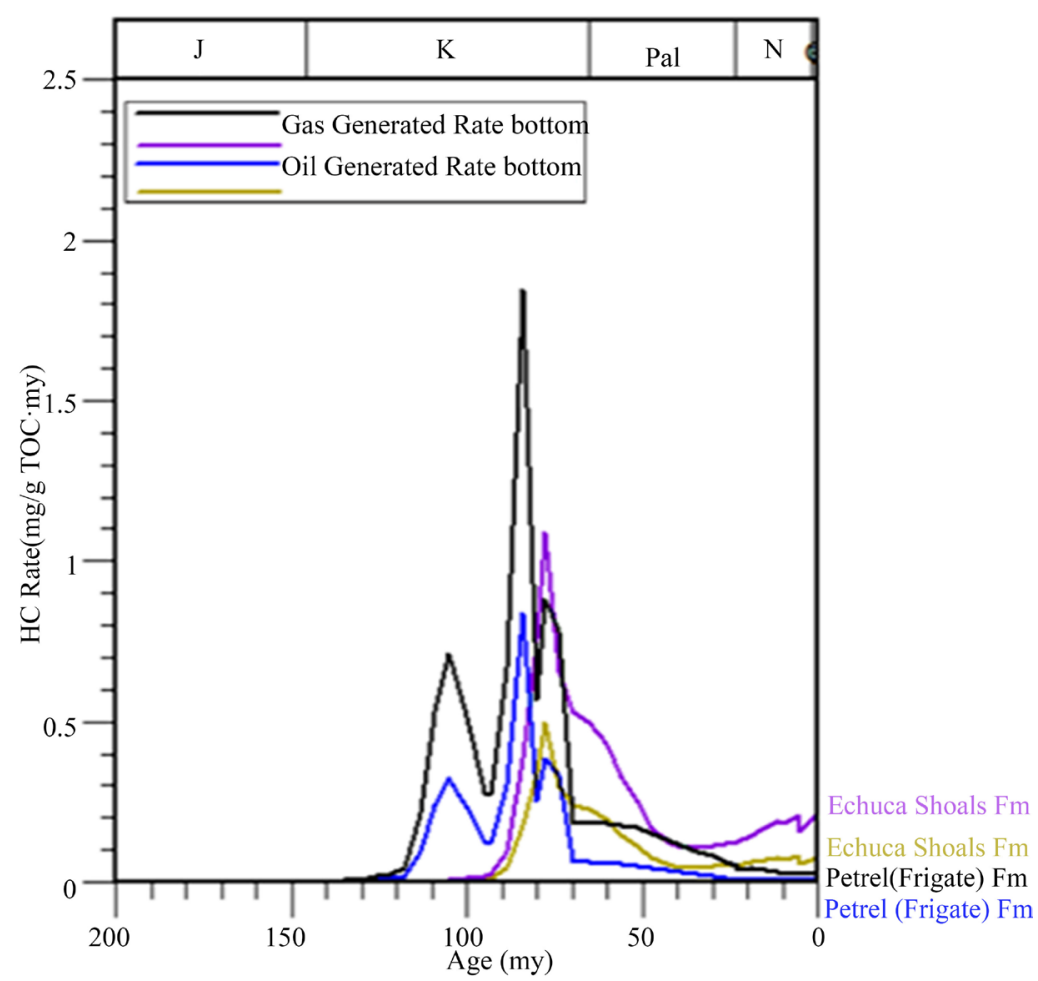

(b)

Figure 15. Modeling results of hydrocarbon generation history in the well Heron 1. (a) Amount of hydrocarbon generation; (b) Rate of hydrocarbon showing the peak generation at the Late Cretaceous for the Petrel (Frigate) and Echuca Shoals formations. 


\subsection{Hydrocarbon Expulsion}

Hydrocarbon expulsion is known as primary migration. Hydrocarbons are expelled from a source rock at discrete phases depending on hydrocarbon saturation of the source rock, conduits-micro fractures, and overpressure caused by oil and gas generation and fluid expansion, temperature increase and capillary pressure. The occurrence of hydrocarbon expulsion is assumed to be happened only when both the fluid pressure and hydrocarbon saturation within the pore reach or exceed a critical value. Hydrocarbon expulsion for each well in the SunsetLoxton and Chuditch fields in the Sahul Platform as well as in the Malita Graben was determined using the BasinMod 1-D. In the well Loxton Shoals 1, the hydrocarbon expelled from the Plover Formation source rock began during the Pleistocene and reached the peak during the Quaternary (Figure 16(a)); similarly in the well Sunset 1 (Figure 16(b)). The timing of preservation in the Sunset-Loxton Shoals field started at Middle Pleistocene at $0.70 \mathrm{Ma}$. In the well Chuditch 1, the hydrocarbon expelled from the Plover, Flamingo, and Echuca Shoals formations began at Middle Eocene, Late Pliocene and Early Miocene, respectively and peaked during the Quaternary (Figure 16(c)). The timing of preservation in the Chuditch field commenced at Late Eocene at 36 Ma for the Plover Formation, at Middle Pleistocene at 0.70 Ma for Flamingo Formation, and at Middle Miocene at 13.60 Ma for Echuca Shoals Formation. In the Heron 1 well the hydrocarbon expelled from the Petrel (Frigate) and Echuca Shoals formations began during the Late Cretaceous (Turonian age) and Early Oligocene, respectively, the Petrel (Frigate) Formation reached the peak at the Late Cretaceous (Maastrichtian age), and the Echuca Shoals Formation at the Quaternary (Figure 16(d)). The timing of preservation in the Malita Graben initiated at Early Paleogene at 64 Ma for the Petrel (Frigate) Formation, and at Early Neogene at 23.30 Ma for Echuca Shoals Formation. The expelling efficiencies of gas and oil from the Plover Formation source rock in the Loxton Shoals 1 well were $5.10 \%$ and $4.90 \%$, respectively and in the well Sunset 1 were $8.47 \%$ and $8.53 \%$, respectively (Table 4). The expelling efficiencies of gas from the Plover, Flamingo and Echuca Shoals formations in the well Chuditch 1 were $73.73 \%$, 2.93\% and 51.09\% and of oil ones were 73.30, 2.71 and 50.87\%, respectively, and in the Heron 1 well of the Malita Graben, the expelling efficiencies of gas from the Petrel (Frigate) and Echuca Shoals formations were $72.38 \%$ and $34.35 \%$ and of oil ones were $60.43 \%$ and $31.71 \%$. These values indicated that the Plover and Echuca Shoals formations source rocks in the well Chuditch 1 and the Petrel (Frigate) and Echuca Shoals formations source rocks in the well Heron 1, except for the Flamingo Formation in the well Chuditch 1, had higher gas and oil expelling efficiencies than the Plover Formation source rock of the wells in the Sunset-Loxton Shoals field. The oil and gas expulsion intensities were similar as shown in the results of Table 4.

\subsection{Hydrocarbon Migration and Accumulations to the Plover Formation in the Sahul Platform}

The secondary migration and differential concentration of hydrocarbon in the Sunset-Loxton Shoals and Chuditch fields are obtained by modelling of the migration pathways to the top of the Plover Formation sandstone reservoir from the Plover, Frigate and Echuca Shoals formations source rocks to make sure that the spelling, begin age, and event names of formations is consistent from well to well (Figure 17). The migration modelling

Table 4. Oil and gas generation, expulsion and efficiency in the Sunset 1, Loxton Shoals 1, Chuditch 1 and Heron 1 wells.

\begin{tabular}{|c|c|c|c|c|c|c|c|}
\hline \multirow{2}{*}{ Well Name } & \multirow{2}{*}{ Formation } & \multicolumn{3}{|c|}{ Oil } & \multicolumn{3}{|c|}{ Gas } \\
\hline & & $\mathrm{G}_{\text {oil }}$ & $\mathrm{E}_{\text {oil }}$ & $\mathrm{Oil}_{\text {eff }}$ & $\mathrm{G}_{\text {gas }}$ & $\mathrm{E}_{\text {gas }}$ & Gas $_{\text {eff }}$ \\
\hline Loxton Shoals 1 & Plover & 14.28 & 0.70 & 4.90 & 31.38 & 1.60 & 5.10 \\
\hline Sunset 1 & Plover & 7.27 & 0.62 & 8.53 & 16.17 & 1.37 & 8.47 \\
\hline \multirow[t]{3}{*}{ Chuditch 1} & Echuca Shoals & 13.27 & 6.75 & 50.87 & 29.32 & 14.98 & 51.09 \\
\hline & Flamingo & 16.98 & 0.46 & 2.71 & 37.53 & 1.10 & 2.93 \\
\hline & Plover & 17.19 & 12.60 & 73.30 & 37.95 & 27.98 & 73.73 \\
\hline \multirow[t]{2}{*}{ Heron 1} & Echuca Shoals & 11.89 & 3.77 & 31.71 & 27.25 & 9.36 & 34.35 \\
\hline & Petrel (Frigate) & 15.39 & 9.30 & 60.43 & 37 & 26.78 & 72.38 \\
\hline
\end{tabular}

where $\mathrm{G}_{\mathrm{oil}}$ is oil generating intensity (mg/g TOC); $\mathrm{E}_{\mathrm{oil}}$ is oil expelling intensity (mg/g TOC); Oil $\mathrm{eff}_{\text {f }}$ is oil expelling efficiency (\%); $\mathrm{G}_{\mathrm{gas}}$ is gas generat-

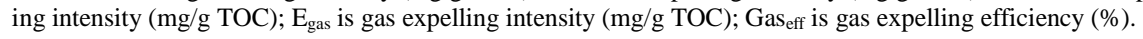




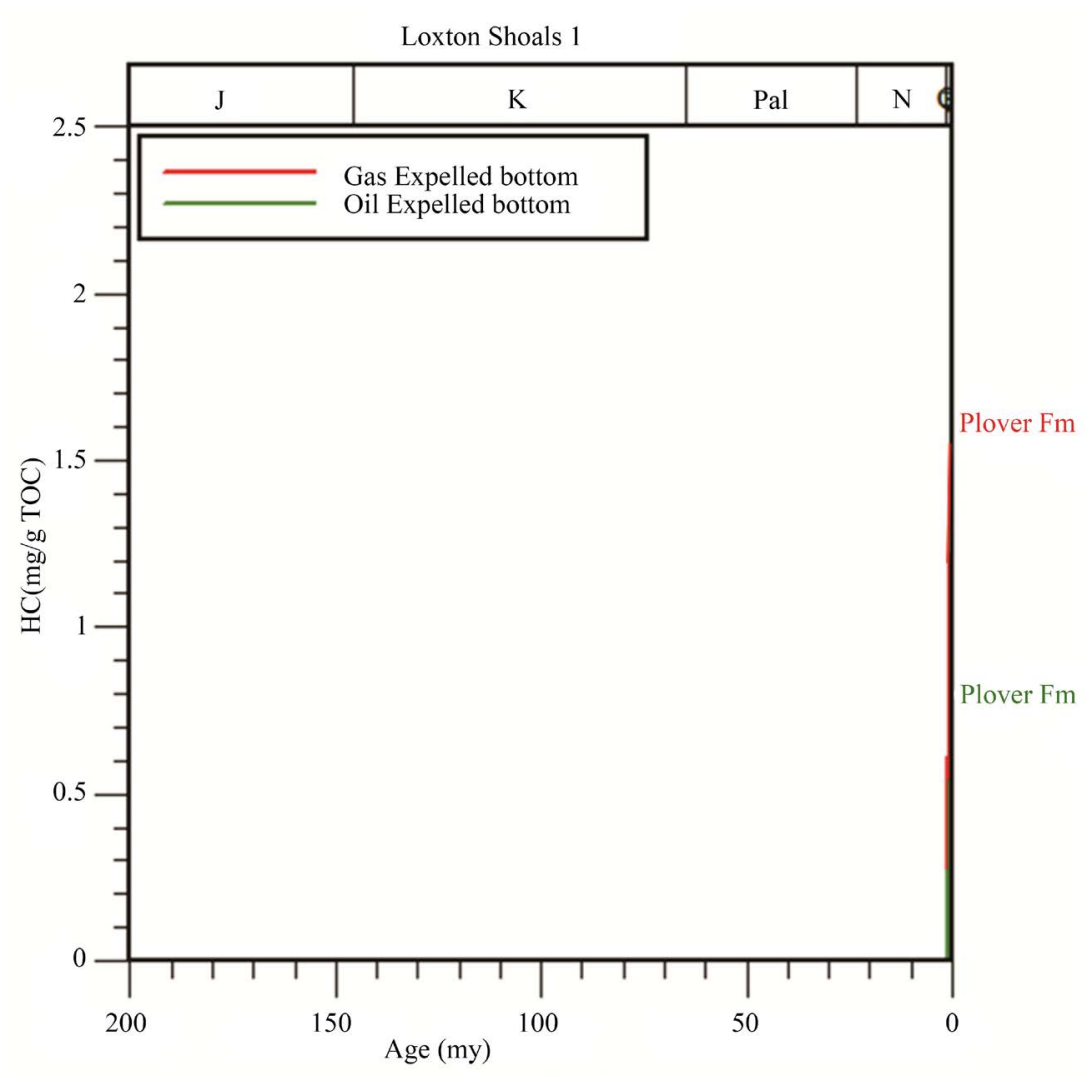

(a)

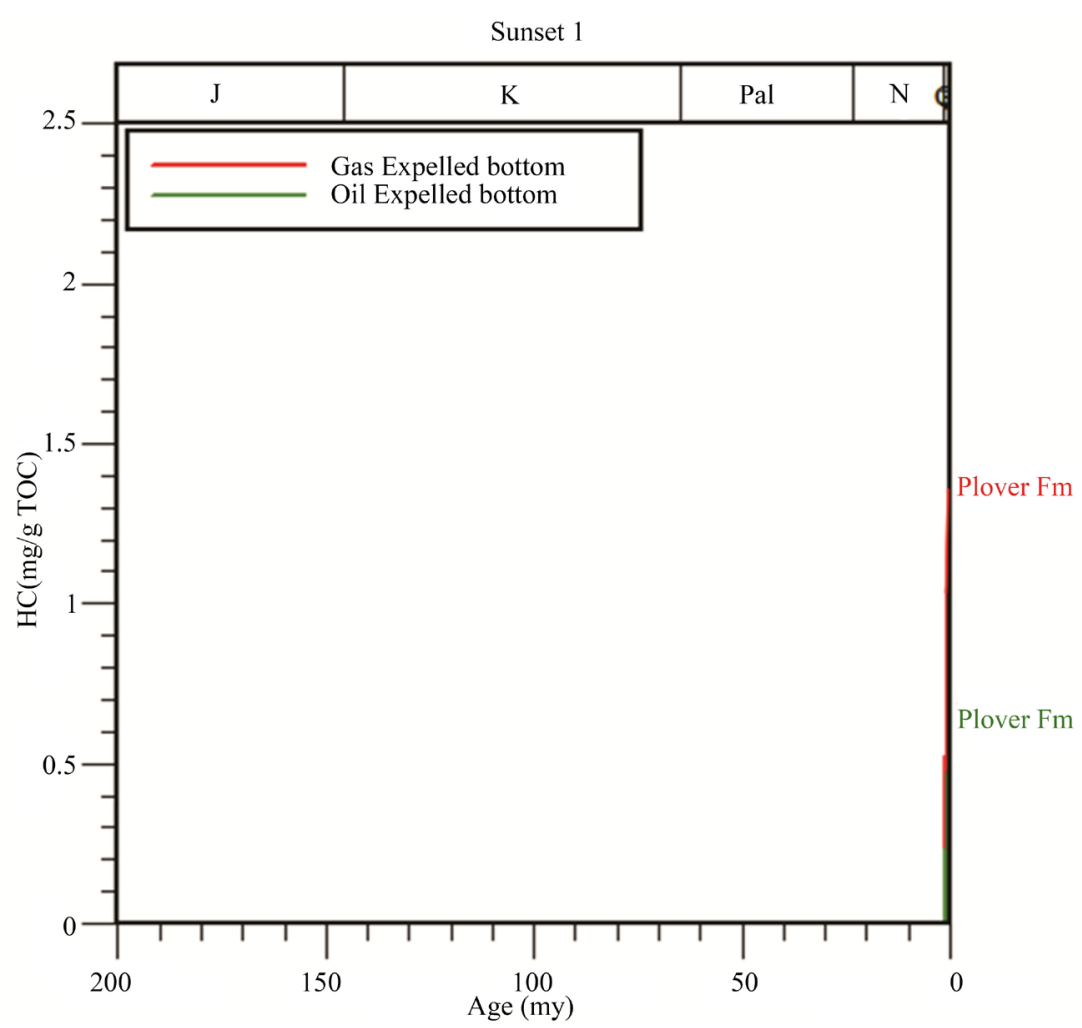

(b) 


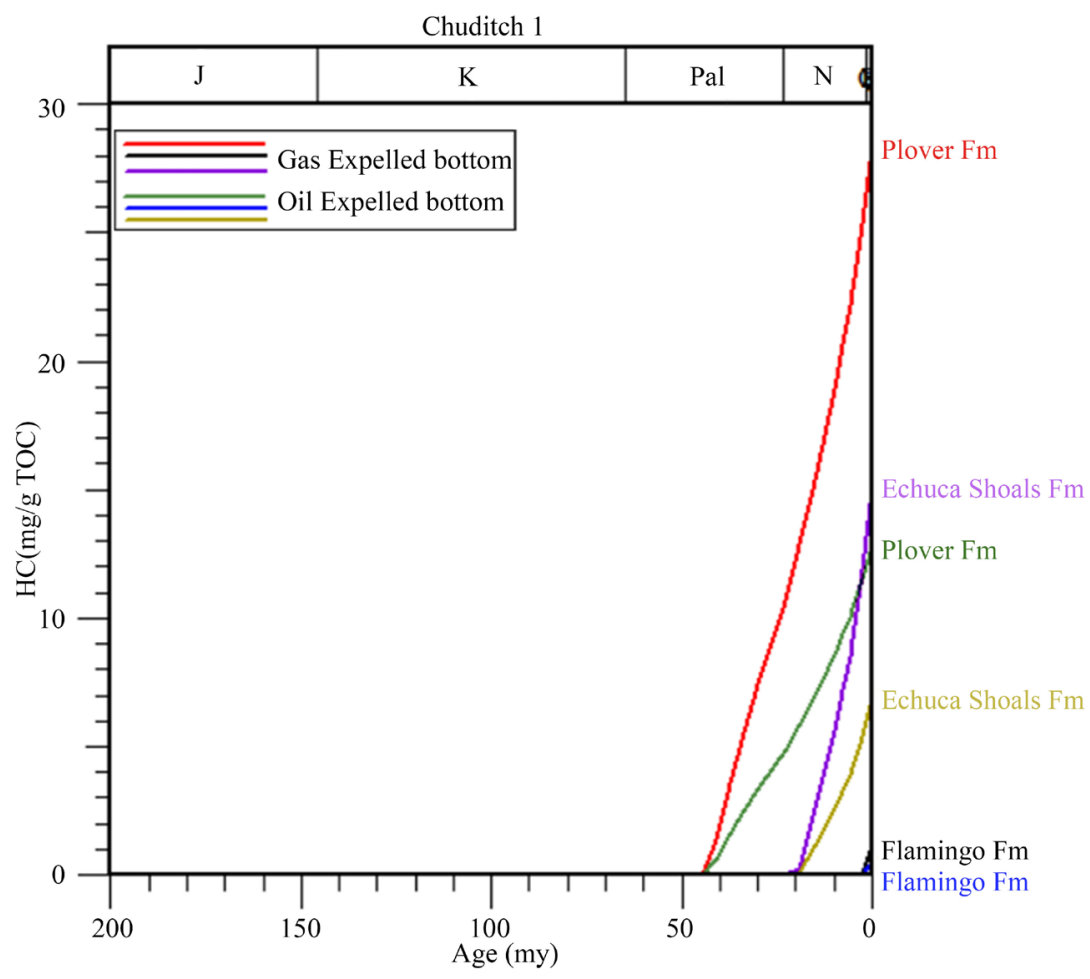

(c)

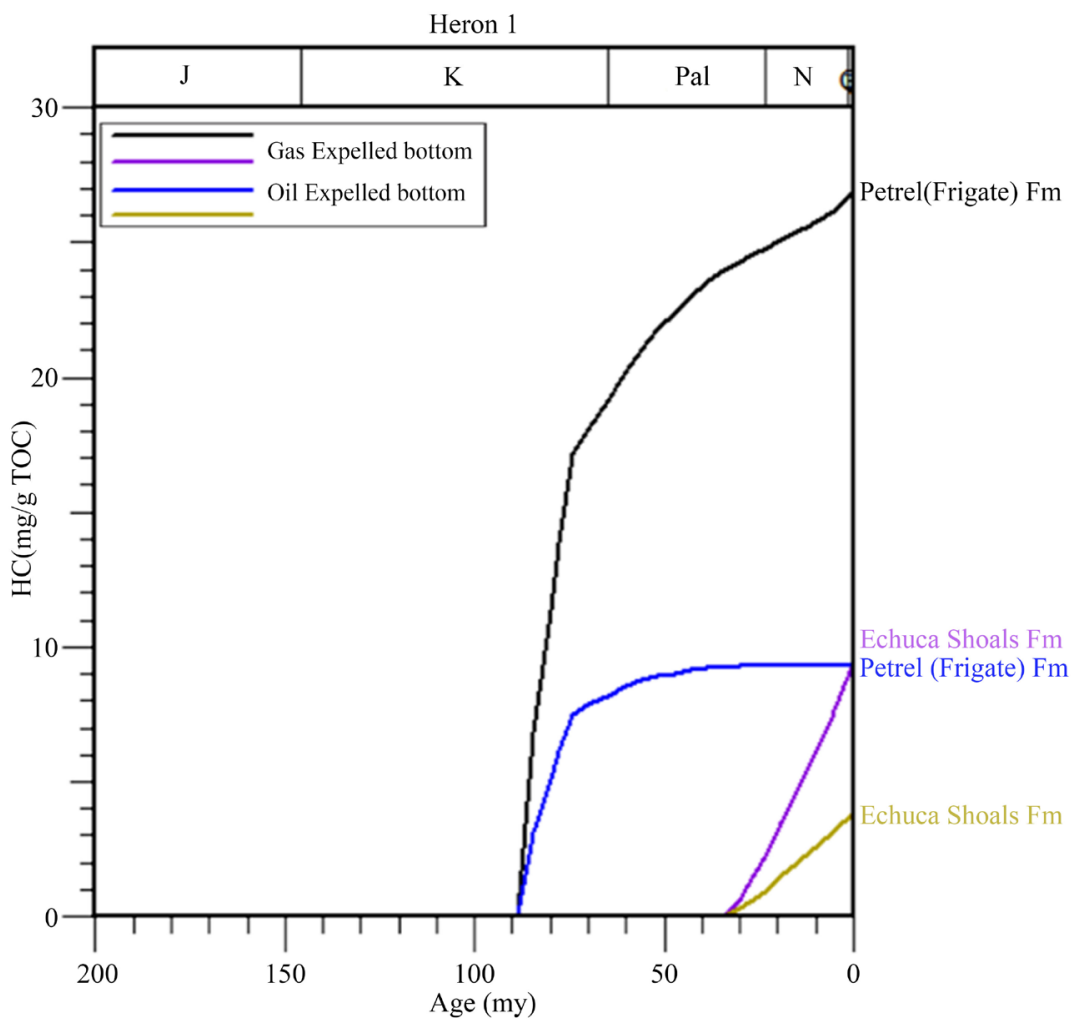

(d)

Figure 16. Modeling results of the oil and gas expulsion histories in the wells Loxton Shoals 1, Sunset 1, Chuditch 1 of the Sahul Platform and well Heron 1 of the Malita Graben. 
R. Jules et al.

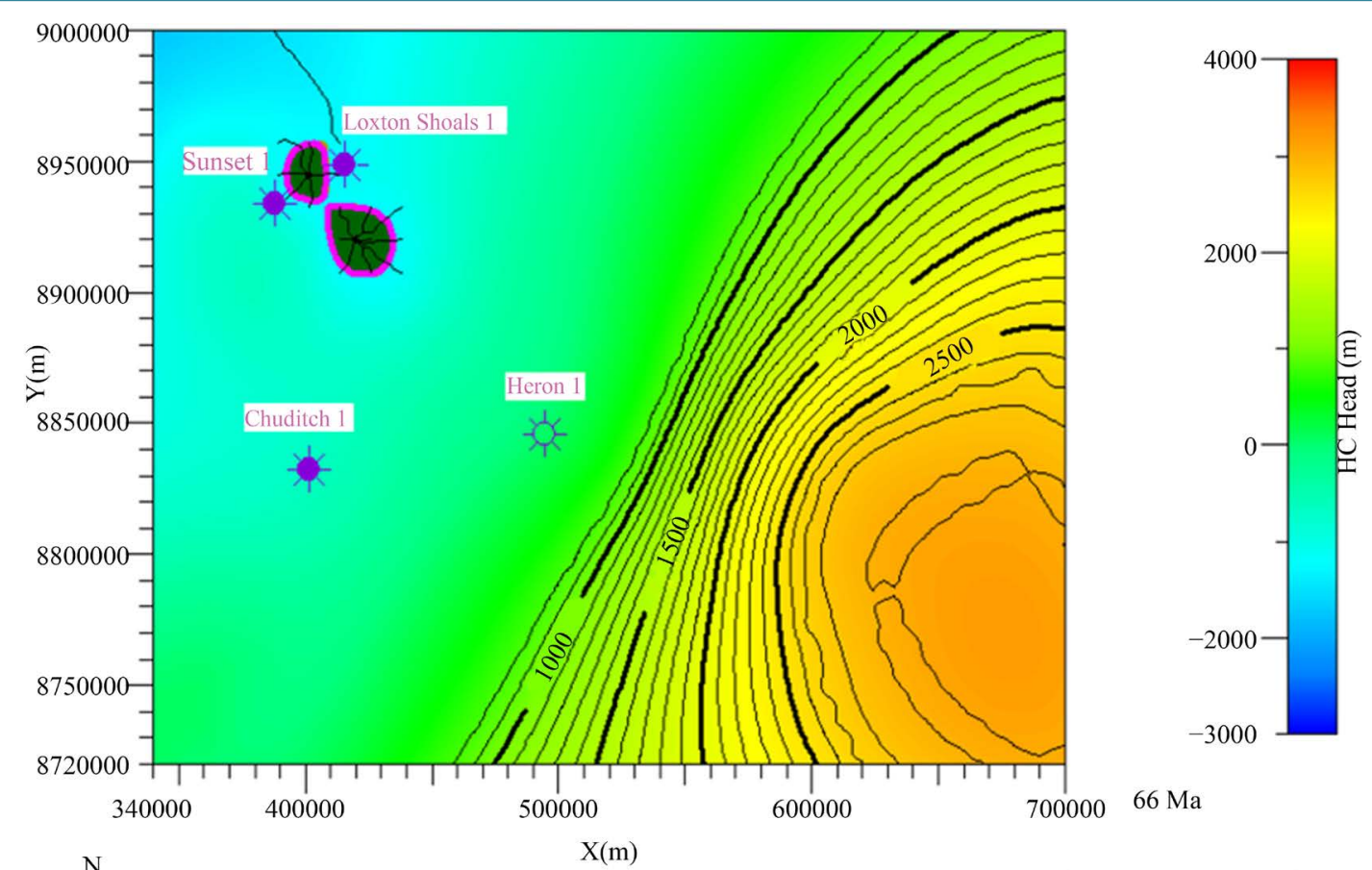

N

$1(\mathrm{~cm})=37900(\mathrm{~m})$

开

(m)

(a)

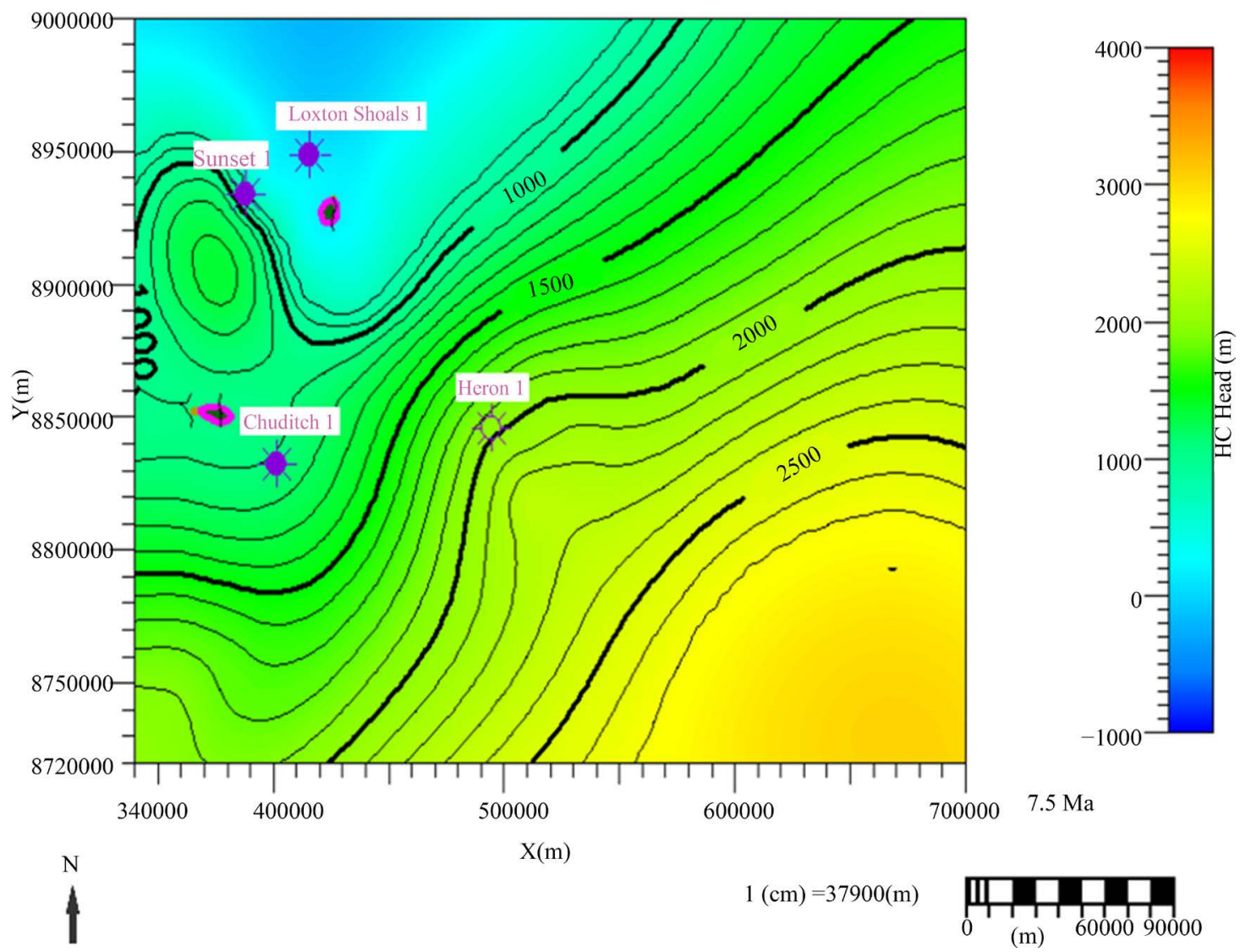

(b) 


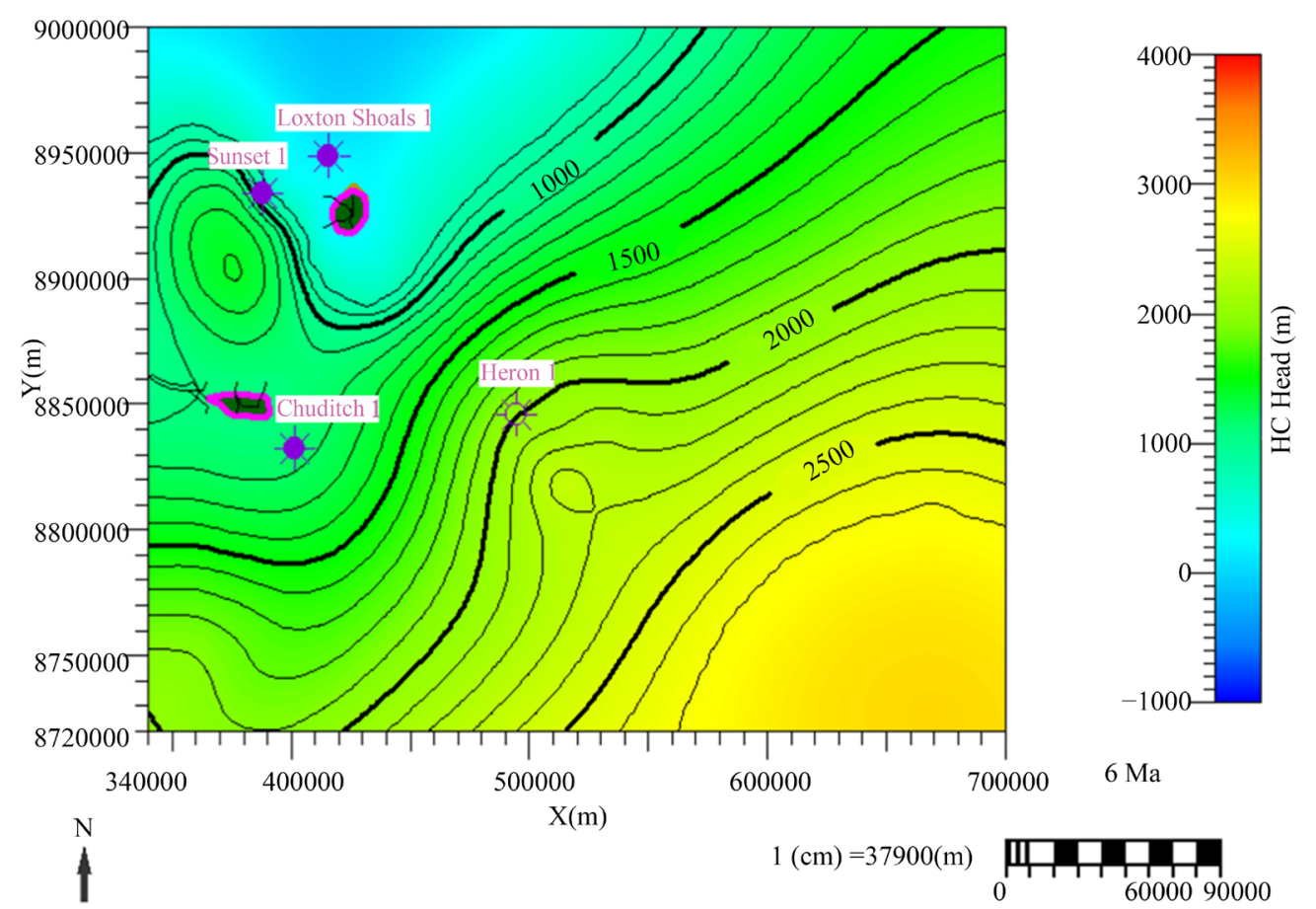

(m)

(c)

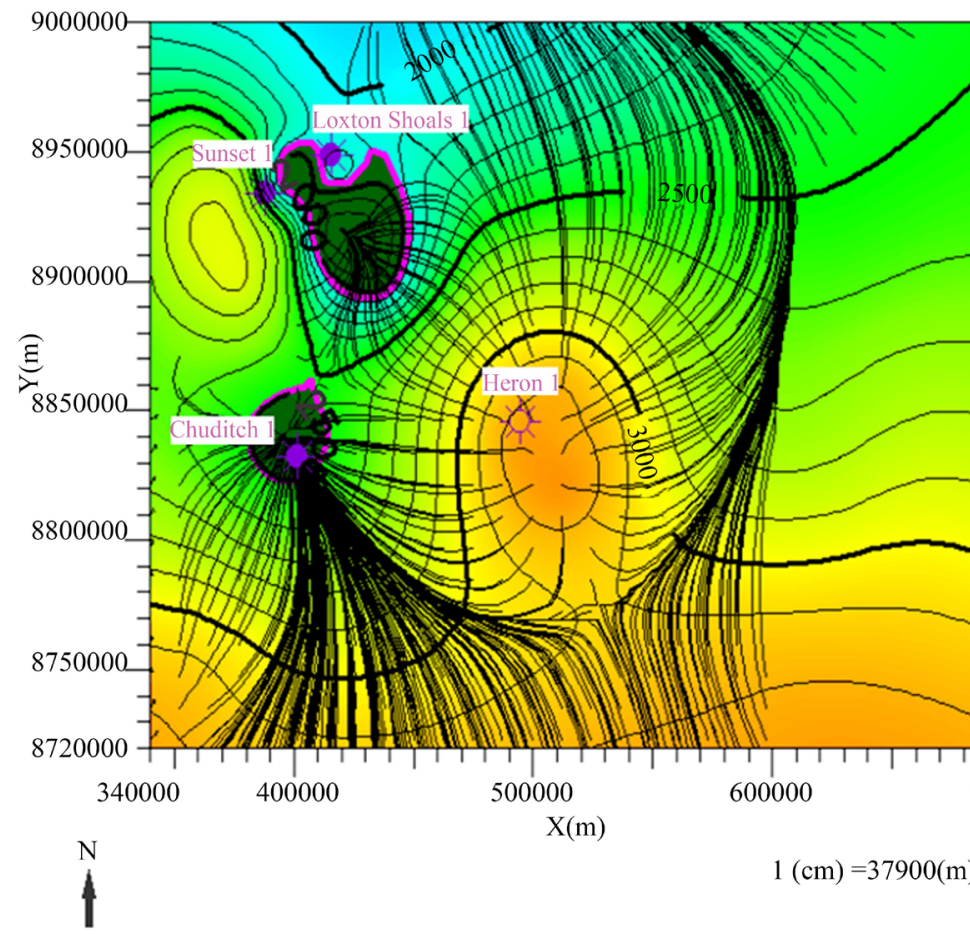

(d)

Figure 17. Modelled hydrocarbon migration pathways to the top of the Plover Formation sandstone reservoir: (a) at 66 Ma; (b) at $7.5 \mathrm{Ma}$; (c) at $6 \mathrm{Ma}$ and (d) at the present day $(0 \mathrm{Ma})$. The wells are denoted by the purple letters, black strings represent the migration pathways and are perpendicular to the contour lines, dark green and magenta polygons are the favorable traps, orange color indicates the main hydrocarbon kitchen, the yellow and green colors indicate mature source rock, and the light blue color represents the lowest hydrocarbon heads in the reservoirs. 
was performed by Basin View and Basin Flow software, using the saturation method with the threshold value of $2 \%$. The modelling has been undertaken with a simple hypothesis relying on the buoyancy approach, that generated fluids will migrate vertically through opening faults to the first carrier bed and will then follow them laterally by unconformity and through sandstone towards the first trap from one side and the compositional gradient inherited from the filling process. During the Late Cretaceous at $66 \mathrm{Ma}$, hydrocarbon migrated mainly from the Oxfordian-Tithonian age Frigate Shale [39] source rock, low-energy marine-shelf depositional environments, in the Malita Graben depocentre (structurally lower) to the Plover Formation reservoir in the Sunset-Loxton Shoals field. Based on the model results (Figure 17(a)) and (Table 5), the Sunset-Loxton Shoals trap was identified with filled area of $943.60 \mathrm{~km}^{2}$ and available pore volume of $2.44 \times 10^{11} \mathrm{bbls}$, whereas the volumes of hydrocarbon entered, accumulated and spilled were $2.39 \times 10^{11}$ bbls, $2.39 \times 10^{11}$ bbls and $0.00 \mathrm{bbl}$, respectively. However, the mass of maximum hydrocarbon potential, hydrocarbon entered, accumulated and hydrocarbon spilled from the trap were $2.75 \times 10^{13} \mathrm{~kg}, 2.68 \times 10^{13} \mathrm{~kg}, 2.68 \times 10^{13} \mathrm{~kg}$, and $0.00 \mathrm{~kg}$ respectively. In the Chuditch field was formed structural closure as a result of the collision tectonics at the Late Miocene to the present day in the region, the hydrocarbon migrated to the Plover Formation reservoir has begun during the Late Miocene at 7.5 Ma and its volume grew up at 6 Ma from the Middle Jurassic Plover Formation source rock in the well Chuditch 1 (Figure 17(b) and Figure 17(c)). Founded on the model results (Figure 17(b)) and (Table 6), the chuditch trap was recognized with filled area of $75.49 \mathrm{~km}^{2}$ and available pore volume of $6.79 \times 10^{8}$ bbls, whereas the volumes of hydrocarbon entered, accumulated and spilled were $1.18 \times 10^{6} \mathrm{bbls}, 1.18 \times 10^{6} \mathrm{bbls}$ and $0.00 \mathrm{bbl}$, respectively. However, the mass of maximum hydrocarbon potential, hydrocarbon entered, accumulated and hydrocarbon spilled from the trap were $1.51 \times 10^{9} \mathrm{~kg}, 1.50 \times 10^{9} \mathrm{~kg}, 1.50 \times 10^{9} \mathrm{~kg}$, and $0.00 \mathrm{~kg}$ respectively.

Table 5. Flow Trap characteristics and properties of accumulated hydrocarbons in Sunset-Loxton Shoals field.

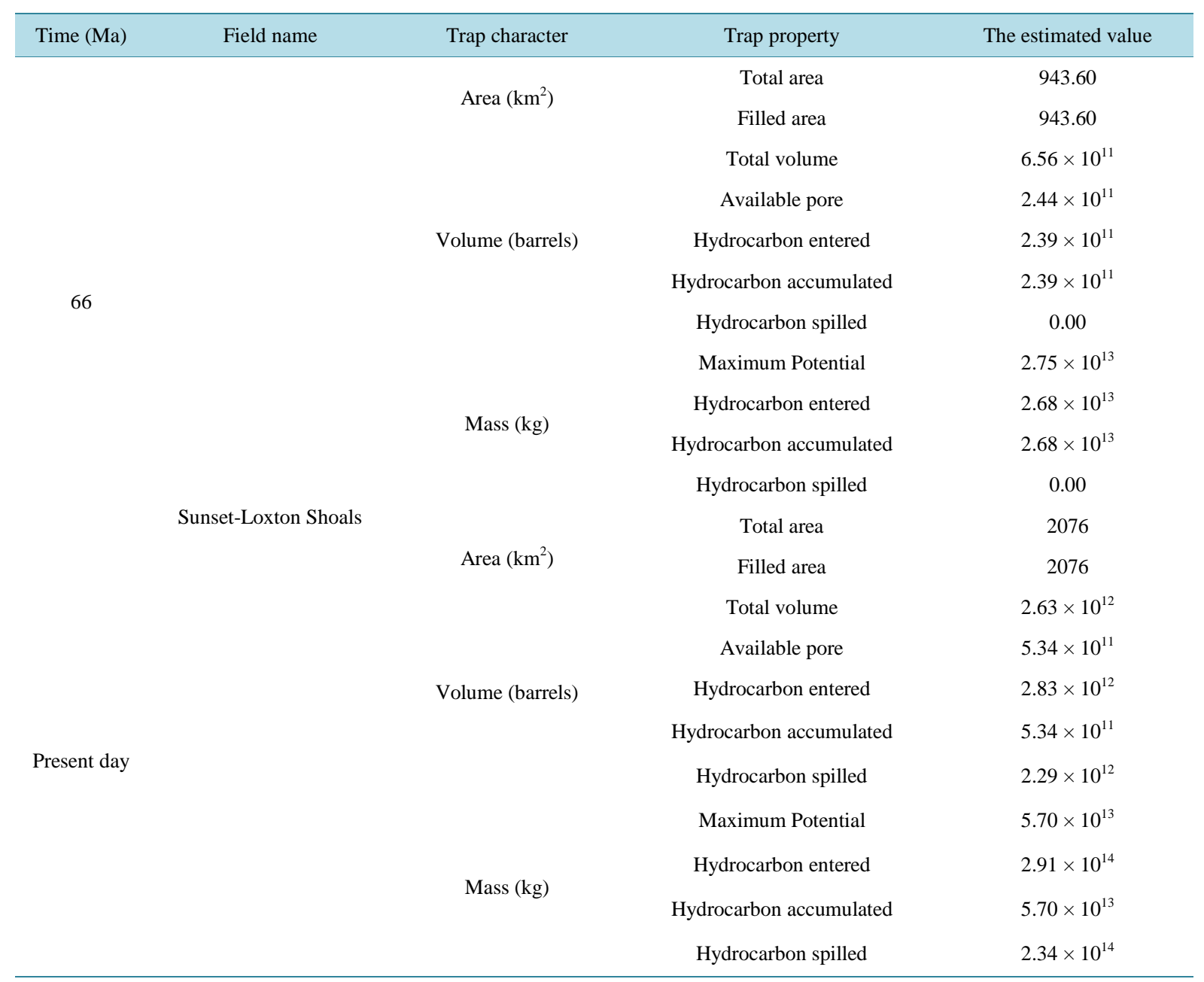


Table 6. Flow Trap characteristics and properties of accumulated hydrocarbons in Chuditch field.

\begin{tabular}{|c|c|c|c|c|}
\hline Time (Ma) & Field name & Trap character & Trap property & The estimated value \\
\hline \multirow{16}{*}{7.5} & \multirow{22}{*}{ Chuditch } & & Total area & 75.49 \\
\hline & & Area $\left(\mathrm{km}^{2}\right)$ & Filled area & 75.49 \\
\hline & & & Total volume & $6.79 \times 10^{8}$ \\
\hline & & & Available pore & $1.41 \times 10^{8}$ \\
\hline & & Volume (barrels) & Hydrocarbon entered & $1.18 \times 10^{8}$ \\
\hline & & & Hydrocarbon accumulated & $1.18 \times 10^{8}$ \\
\hline & & & Hydrocarbon spilled & 0.00 \\
\hline & & & Maximum Potential & $1.47 \times 10^{10}$ \\
\hline & & & Hydrocarbon entered & $1.23 \times 10^{10}$ \\
\hline & & Mass (kg) & Hydrocarbon accumulated & $1.23 \times 10^{10}$ \\
\hline & & & Hydrocarbon spilled & 0.00 \\
\hline & & & Total area & 981.30 \\
\hline & & Area $\left(\mathrm{km}^{2}\right)$ & Filled area & 981.30 \\
\hline & & & Total volume & $1.88 \times 10^{11}$ \\
\hline & & & Available pore & $3.33 \times 10^{10}$ \\
\hline & & Volume (barrels) & Hydrocarbon entered & $2.60 \times 10^{12}$ \\
\hline \multirow{6}{*}{ Present day } & & & Hydrocarbon accumulated & $3.33 \times 10^{10}$ \\
\hline & & & Hydrocarbon spilled & $2.57 \times 10^{12}$ \\
\hline & & & Maximum Potential & $3.44 \times 10^{12}$ \\
\hline & & & Hydrocarbon entered & $2.69 \times 10^{14}$ \\
\hline & & Mass (kg) & Hydrocarbon accumulated & $3.44 \times 10^{12}$ \\
\hline & & & Hydrocarbon spilled & $2.66 \times 10^{14}$ \\
\hline
\end{tabular}

At the present day, in the Sunset-Loxton Shoals field, the hydrocarbon migration to the Plover Formation reservoir overlain by the claystones of the Elang (Laminaria), Echuca Shoals, and Wangarlu formations effective seal rocks started during the Late Cretaceous, plus at the Middle Paleogene from the Middle Jurassic Plover Formation source rock in the well Chuditch 1and at the Late Paleogene from the Early Cretaceous age Echuca Shoals Formation source rock in the well Heron 1, and at the Early Neogene from the Early Cretaceous Echuca Shoals Formation source rock in the well Chuditch 1 (structurally lower). The migration pathways trends were maximized during the Quaternary and continued up to the present day. Concerning the model results (Figure 17(d)) and (Table 5), the Sunset-Loxton Shoals trap was identified with filled area of $2076 \mathrm{~km}^{2}$ and available pore volume of $5.34 \times 10^{11}$ bbls, whereas the volumes of hydrocarbon entered, accumulated and spilled were $2.83 \times 10^{12}$ bbls, $5.34 \times 10^{11}$ bbls and $2.29 \times 10^{12}$ bbls, respectively. However, the mass of maximum hydrocarbon potential, hydrocarbon entered, accumulated and hydrocarbon spilled from the trap were $5.70 \times 10^{13} \mathrm{~kg}$, $2.91 \times 10^{14} \mathrm{~kg}, 5.70 \times 10^{13} \mathrm{~kg}$, and $2.34 \times 10^{14} \mathrm{~kg}$ respectively. In the Chuditch field, the hydrocarbon migration to the Plover Formation reservoir overlain by the claystones of the Flamingo, Echuca Shoals, and Wangarlu formations effective seal rocks was initiated during the Late Miocene from the Middle Jurassic Plover Formation source rock in the well Chuditch 1, as well as from the Upper Jurassic Frigate Shale and Lower Cretaceous Echuca Shoals source rocks formations, marine depositional environments respectively, in the Malita Graben. The migration pathways trends were maximized during the Quaternary and continued up to the present day. Based on the model results (Figure 17(d)) and (Table 6), the Chuditch trap was known as a filled area of 981.30 
$\mathrm{km}^{2}$ and available pore volume of $3.33 \times 10^{10} \mathrm{bbls}$, whereas the volumes of hydrocarbon entered, accumulated and spilled were $2.60 \times 10^{12}$ bbls, $3.33 \times 10^{10}$ bbls and $2.57 \times 10^{12}$ bbls, respectively. However, the mass of maximum hydrocarbon potential, hydrocarbon entered, accumulated and hydrocarbon spilled from the trap were $3.44 \times 10^{12} \mathrm{~kg}, 2.69 \times 10^{14} \mathrm{~kg}, 3.44 \times 10^{12} \mathrm{~kg}$, and $2.66 \times 10^{14} \mathrm{~kg}$ respectively. The model results have also shown that the dark green and magenta polygons where the migration pathways end relate to the effective traps, the orange color characterises the most active hydrocarbon kitchens and is located in the southeast and south of the Sahul Platform with maximum hydrocarbon head of $3200 \mathrm{~m}$, the yellow and green colors show mature source rock, the light blue color represents the lowest hydrocarbon heads in the reservoirs and the black strings represent the migration pathways and they are perpendicular to the contour lines. The main migration pathways are from the south-eastward and southward of the Sunset-Loxton Shoals field, and from southward and eastward of the Chuditch field, i.e., from the hydrocarbon source kitchens of the Malita Graben depocentre.

\section{Conclusion}

Structural evolution analysis, and data from the wells Loxton Shoals 1, Sunset 1, Chuditch 1, and Heron 1of the northern Bonaparte Basin, Australia, with 1D, 2D and 3D Basin Modelling were used to clarify the geological conditions and reconstruct hydrocarbon accumulation processes in the Sunset-Loxton Shoals and Chuditch fields of the Sahul Platform. The source rock of the Plover Formation in the Sunset-Loxton Shoals field dated Early-Middle Jurassic; in the well Loxton Shoals 1 it was a fair-to-very good source richness with an overall poor hydrocarbon generative potential and it reached the late mature oil window; however in the well Sunset 1 it was a poor-to-very good source rock with an overall good hydrocarbon generating potential and it reached the middle mature oil window. The Middle Jurassic Plover Formation source rock in the well Chuditch 1 of the Chuditch field was a good-to-very good organic richness with an overall fair-to-good hydrocarbon generative potential, and it attained the Late mature oil window; the Late Jurassic-Early Cretaceus Flamingo Formation source rock in the same well was a fair-to-good source rock with a fair hydrocarbon generation potential, and it reached mid-mature oil window, whereas the Early Cretaceous Echuca Shoals Formation source rock in the same well was a good-to-very good organic richness with an overall good hydrocarbon generating potential, and reached mid-mature oil window. In the Malita Graben depocentre, the Late Jurassic-Early Cretaceous Petrel (Frigate) Formation source rock in the well Heron 1 was an overall very good source richness with poor-to-very good hydrocarbon generating potential, and reached wet gas window, and the Early Cretaceous Echuca Shoals Formation source rock in the same well was an overall good-to-very good organic richness with poor-to-good hydrocarbon genetative potential, and it attained wet gas window at the present day. The analyses of organic matter indicated that the source rocks in the study area and Malita Graben were gas prone with kerogen types $\mathrm{II}_{2}$ \& III and III predominantly. The Middle Jurassic Plover Formation sandstone reservoir in the Sunset-Loxton field overlain by the claystones of the Elang (Laminaria), Echuca Shoals, and Wangarlu formations effective seal rocks was a fair-to-good porosity and negligible-to-low permeability for gas beds (poor reservoir quality) in the well Loxton Shoals 1 and was a negligible-to-good porosity and very low-to-very good permeability for gas beds (poor-to-very good reservoir quality) in the well Sunset 1, whereas the Middle Jurassic Plover Formation sandstone reservoir in the Chuditch field overlain by the claystones of the Flamingo, Echuca Shoals, and Wangarlu formations effective seal rocks was a negligible-to-good porosity and very low-to-very good permeability for gas beds (very poor-to-very good reservoir quality). The intensities of gas generation and expulsion were more than of oil ones either in the Sahul Platform or in the Malita Graben. The Plover and Echuca Shoals formations source rocks in the well Chuditch 1 and the Petrel (Frigate) and Echuca Shoals formations source rocks in the well Heron 1, except for the Flamingo Formation in the well Chuditch 1, had higher gas and oil expelling efficiencies than the Plover Formation source rock of the wells in the Sunset-Loxton Shoals field; the gas and oil expulsion intensities were similar. In the Sunset-Loxton Shoals field, hydrocarbon migrated to the Plover Formation sandstone reservoir mainly from the Upper Jurassic Frigate Shale source rock in the Malita Graben depocentre during the Late Cretaceous at $66 \mathrm{Ma}$, plus from the Middle Jurassic Plover Formation source rock in the well Chuditch 1 at the Middle Paleogene, and during the Late Paleogene from the Early Cretaceous Echuca Shoals Formation source rock in the well Heron 1, whereas at the Early Neogene from the Early Cretaceous Echuca Shoals Formation source rock in the well Chuditch 1 (structurally lower). In the Chuditch field, the hydrocarbon migration to the Plover Formation sandstone reservoir was initiated during the Late Miocene from the Middle Jurassic Plover Formation source rock in the well Chuditch 1, as well as from the Upper Jurassic Frigate 
Shale and Lower Cretaceous Echuca Shoals source rocks formations in the well Heron 1. The main hydrocarbon source kitchen is located in the southern of the study area, to be precise, in the Malita Graben depocentre and the direction of migration pathways towards the low hydrocarbon heads in the Sahul Platform, which are ranged from 3200 to 2300 and $2100 \mathrm{~m}$ at the present day. The traps in the Sahul Platform have been effective to accumulate the migrated hydrocarbons.

\section{Acknowledgements}

The authors would like to thank the Department of Oil and Gas Exploration, Faculty of Earth Resources, China University of Geosciences (Wuhan), for their financial support and the supply of all the data.

\section{References}

[1] Longley, I.M., Buessenschuett, C., Clydsdale, L., Cubitt, C.J., Davis, R.C., Johnson, M.K., Marshall, N.M., Murray, A.P., Somerville, R., Spry, T.B. and Thompson, N.B. (2002) The North West Shelf of Australia-A Woodside Perspective. In: Keep, M. and Moss, S.J. Eds., The Sedimentary Basins of Western Australia 3: Proceedings of the Petroleum Exploration Society of Australia Symposium, October 20-23 2002, Perth, WA, 28-88.

[2] Preston, J.C. and Edwards, D.S. (2000) The Petroleum Geochemistry of Oils and Source Rocks from the Northern Bonaparte Basin, Offshore Northern Australia. The APPEA Journal, 40, 257-282.

[3] Abbassi, S., George, S.C., Edwards, D.S., et al., (2014) On the Filling and Leakage of Petroleum from Traps in the Laminaria High Region of the Northern Bonaparte Basin, Australia. Marine and Petroleum Geology, 59, 91-113. http://dx.doi.org/10.1016/j.marpetgeo.2014.07.030

[4] Barret, A.G., Hinde, A.L. and Kennard, J.M. (2004) Undiscovered Resource Assessment Methodologies and Application to the Bonaparte Basin. In: Ellis, G.K., Baillie, P.W. and Munson, T.J., Eds., Timor Sea Petroleum Geoscience, Proceedings of the Timor Sea Symposium, Darwin, 19-20 June 2003, 353-372.

[5] Magoon, L.B. and Dow, W.G. (1994) The Petroleum System-From Source to Trap. AAPG Memoir 60, 655 p.

[6] RDPIFR (2007) Petroleum Reserves, and Resources Summary. Dated 31 December 2007. Department of Regional Development, Primary Industry, Fisheries and Resources, Northern Territory.

[7] Seggie, R.J., Ainsworth, R.B., Johnson, D.A., Koninx, J.P.M., Marshall, N., Murray, A.P., Phillips, S.E., Spaargaren, R. and Stephenson, P.M. (2003) The Sunrise-Troubadour Gas Condensatefields, Timor Sea, Australasia. In: Halbouty, M.T., Ed., Giant Oil and Gas Fields of the Decade 1990-1999, AAPG Memoir 78, 189-209.

[8] TSDA (2007) Timor Sea Designated Authority, Annual Report 2007.

[9] Edwards, D.S., Boreham, C.J., Zumberge, J.E., Hope, J.M., Kennard, J.M. and Summons, R.E. (2006) Hydrocarbon families of the Australian North West Shelf: A Regional Synthesis of the Bulk, Molecular and Isotopic Composition of Oils and Gases. AAPG International Conference and Exhibition, Perth, Australia, 5-8 November 2006.

[10] Ahmad, M. and Musto, T.J. (2013) Chapter 36: Bonaparte Basin. In: Ahmad, M. and Munson, T.J. (Compilers), Geology and Mineral Resources of the Northern Territory, Northern Territory Geological Survey, Special Publication 5.

[11] Geoscience Australia (2014) Regional Geology of the Bonaparte Basin. Australia 2014 Offshore Petroleum Exploration Acreage Release. http://www.petroleum-acreage.gov.au/files/files/2014/documents/regional-geology/Regional Geology-Bonaparte.pdf

[12] Whittam, D.B., Norvick, M.S. and McIntyre, C.L. (1996) Mesozoic and Cainozoic tectonostratigraphy of Western ZOCA and Adjacent Areas. The APPEA Journal, 36, 209-231.

[13] Gorter J.D. (1998) Revised Upper Permian Stratigraphy of the Bonaparte Basin. In: Purcell, P.G. and Purcell, R.R., Eds., The Sedimentary Basins of Western Australia 2: Proceedings of the Petroleum Exploration Society of Australia Symposium, Perth, 213-228.

[14] Gorter J.D., Nicoll R.S., Metcalfe I., Willink R.J. and Ferdinando D. (2009) The Permian-Triassic Boundary in Western Australia: Evidence from the Bonaparte and Northern Perth Basins-Exploration Implications. APPEA Journal, 49, 311-336.

[15] Pickard, G.L. (1964) Descriptive Physical Oceanography: An Introduction, Macmillan, New York.

[16] Haq, B.U., and Shutter, S.R. (2008) A Chronology of Paleozoic Sea-Level Changes. Science, 322, 64-68. http://dx.doi.org/10.1126/science.1161648

[17] Sclater, J.G. and Christie, P.A.F. (1980) Continental Stretching: An Explanation of the Post-Mid-Cretaceous Subsidence of the Central North Sea Basin. Journal of Geophysical Research, 85, 3711-3739.

[18] Steckler, M.S. and Watts, A.B. (1978) Subsidence of the Atlantic Type Continental Margin off New York. Earth and 
Planetary Science Letters, 41, 1-13. http://dx.doi.org/10.1016/0012-821x(78)90036-5

[19] Van Krevelen, D.W. (1961) Coal: Typology-Chemistry-Physics-Constitution. Elsevier, Amsterdam.

[20] Mukhopadhyay, P.K., Wade, J.A. and Kruge, M.A. (1995) Organic Facies and Maturation of Cretaceous/Jurassic Rocks and Possible Oil-Source Rock Correlation Based on Pyrolysis of Asphaltenes, Scotian Basin, Canada. Organic Geochemistry, 22, 85-104. http://dx.doi.org/10.1016/0146-6380(95)90010-1

[21] Aziz, K. and Settari, A. (1986) Petroleum Reservoir Simulation. Elsevier Applied Science Publishers, London.

[22] Huyakorn, P.S. and Pinder, G.F. (1983) Computational Methods in Subsurface Flow. Academic Press, Inc., San Diego.

[23] Sweeney, J.J. and Burnham, A.K. (1990) Evaluation of a Simple Model of Vitrinite Reflectance Based on Chemical Kinetics. American Association of Petroleum Geologist Bulletin, 74, 1559-1570.

[24] Pepper, A.S. (1991) Estimating the Petroleum Expulsion Behavior of Source Rocks: A Novel Quantitative Approach. In: England, W.A. and Fleet, A.J., Eds., Petroleum Migration, Geological Society (London) Special Publication 59, 9-31.

[25] Waples, D.W. (1998) Basin Modeling: How Well Have We Done? In: Düppenbecker, S.J. and Iliffe, J.E., Eds., Basin Modeling: Practice and Progress, Geological Society (London) Special Publication, 144, 1-14. http://dx.doi.org/10.1144/GSL.SP.1998.141.01.01

[26] Schowalter T.T. (1979) Mechanics of Secondary Hydrocarbon Migration and Entrapment. AAPG Bulletin, 25, 723760.

[27] England, W.A., Mackenzie, D.M., Mann, D.M., et al. (1987) The Movement and Entrapment of Petroleum Fluids in the Subsurface. Journal of the Geological Society, 144, 327-347. http://dx.doi.org/10.1144/gsjgs.144.2.0327

[28] Verweij, J.M. (1993) Hydrocarbon Migration Systems Analysis. Elsevier, Oxford.

[29] Dahlberg, E.C. (1995) Applied Hydrodynamics in Petroleum Exploration. 2nd Edition, Springer-Verlag, New York. http://dx.doi.org/10.1007/978-1-4612-4258-1

[30] Willis, D.G. (1982) Entrapment of Petroleum. In: Moody, G.B., Ed., Petroleum Exploration Handbook: A Practical Manual Summarizing the Application of Earth Sciences to Petroleum Exploration, McGraw Hill, New York.

[31] Davis, R.W. (1987) Analysis of Hydrodynamic Factors in Petroleum Migration and Entrapment. AAPG Bulletin, 71, 643-649.

[32] Berg, R.R. (1975) Capillary Pressures in Stratigraphic Traps. AAPG Bulletin, 59, 939-956.

[33] Hocott, C.R. (1938) Interfacial Tension between Water and Oil under Reservoir Conditions of up to Pressures of 3800 Psia and Temperatures of $180^{\circ} \mathrm{F}$. AIME Transactions, 132, 184-190.

[34] Ungerer, Ph. (1993) Modelling of Petroleum Generation and Expulsion-An Update to Recent Reviews. In: Dore, A.G., Augustson, J.H., Hermanrud, C., Stewart, D.J. and Sylta, Ø., Eds., Basin Modelling: Advances and Applications (Norwegian Petroleum Society Special Publication), Elsevier, Amsterdam, 219-232.

[35] Peters, K.E., Moldown, J.M., Schoell, M. and Hempkins, W.B. (1986) Petroleum Isotopic and Biomarker Composition Related to Source Rock Organic Matter and Depositional Environment. Organic Geochemistry, 10, 17-27. http://dx.doi.org/10.1016/0146-6380(86)90006-9

[36] Peters, K.E. and Casa, M.R. (1994) Applied Source Rock Geochemistry. In: Magoon L.B. and Dow W.G., Eds., The Petroleum System: From Source to Trap, American Association of Petroleum Geologists, Tulsa, 93-120.

[37] Levorsen, A.I. (1967) Geology of Petroleum. 2nd Edition, W. H. Freeman and Company, San Franciso, CA.

[38] Selley, R.C. (1988) Applied Sedimentology. 3rd Edition, London.

[39] Mory, A.J. (1991) Geology of the Offshore Bonaparte Basin, Northwestern Australia. Geological Survey of Western Australia Report 29. 


\section{Submit or recommend next manuscript to SCIRP and we will provide best service for you:}

Accepting pre-submission inquiries through Email, Facebook, Linkedin, Twitter, etc A wide selection of journals (inclusive of 9 subjects, more than 200 journals)

Providing a 24-hour high-quality service

User-friendly online submission system

Fair and swift peer-review system

Efficient typesetting and proofreading procedure

Display of the result of downloads and visits, as well as the number of cited articles

Maximum dissemination of your research work

Submit your manuscript at: http://papersubmission.scirp.org/ 